Portland State University

PDXScholar

1987

\title{
Spatial and temporal characteristics of surface air temperature for Portland, Oregon
}

\author{
Li-min Yang \\ Portland State University
}

Follow this and additional works at: https://pdxscholar.library.pdx.edu/open_access_etds

Part of the Climate Commons, and the Geography Commons Let us know how access to this document benefits you.

\section{Recommended Citation}

Yang, Li-min, "Spatial and temporal characteristics of surface air temperature for Portland, Oregon" (1987). Dissertations and Theses. Paper 3735.

https://doi.org/10.15760/etd.5619

This Thesis is brought to you for free and open access. It has been accepted for inclusion in Dissertations and Theses by an authorized administrator of PDXScholar. Please contact us if we can make this document more accessible: pdxscholar@pdx.edu. 
AN ABSTRACT OF THE THESIS OF Li-min Yang for the Master of Science in Geography presented August 13, 1987.

Title: Spatial and Temporal Characteristics of Surface Air Temperature For Portland, Oregon

APPROVED BY MEMBERS OF THE THESIS COMMITTEE:

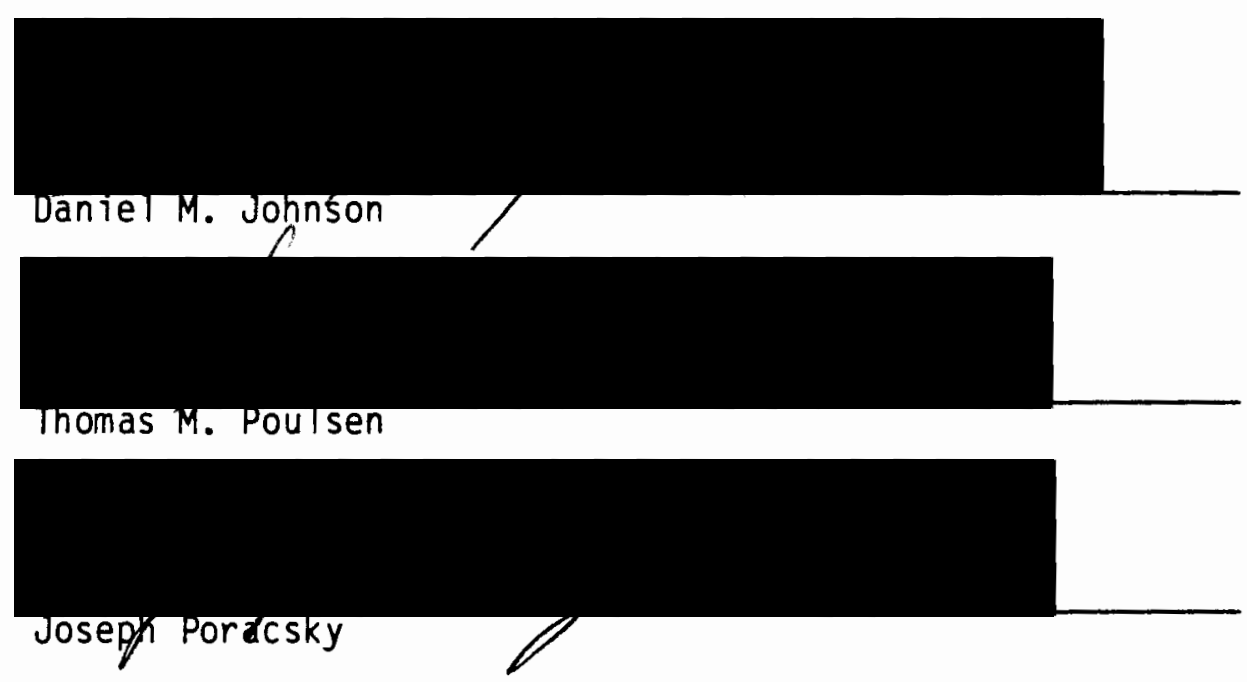

This study examines the spatial and temporal characteristics of the surface air temperature in Portland, Oregon. Spatial temperature patterns indicate that the dominant control factors on seasonal temperature distribution are local topography, elevation, and urban-rural differences in surface structure. A heat island exists in the Portland area; the intensity of the heat island ranges from $4^{\circ}$ to $10^{\circ} \mathrm{F}$, and varies throughout the year. The strongest heat island is found in the July minimum temperature. Temperature distribution in 
Portland and the adjacent area is affected by winds and rainy conditions, but less influenced under overcast skies. The long-term temperature over the last century shows that Portland's mean annual temperature trends are $0.057^{\circ} \mathrm{F} / \mathrm{yr}$ and $0.052^{\circ} \mathrm{F} / \mathrm{yr}$ in the two warming periods 1900-1940 and 1961-1984, respectively, and these warming trends are largely due to warming in spring and early summer as well as in winter months except January. Comparisons between Portland and other local non-urban climatic stations show a general warming trend in Portland since the end of the last century, which is $0.028^{\circ} \mathrm{F} / \mathrm{yr}$ in the mean annual temperature, and $0.017^{\circ} \mathrm{F} / \mathrm{yr}$ in maximum temperature after the regional trends are removed. Monthly mean temperature in July and January demonstrate a warming by $0.023^{\circ} \mathrm{F} / \mathrm{yr}$ and $0.015^{\circ} \mathrm{F} / \mathrm{yr}$ at Portland, respectively. All these warming trends are due mainly to the impact of urbanization. It is found that the cooling effect on the northern Willamette Valley due to the presence of the Columbia Gorge is most noticeable in the daytime and in January. 
SPATIAL AND TEMPORAL CHARACTERISTICS OF SURFACE AIR TEMPERATURE FOR PORTLAND, OREGON

\author{
by \\ LI -MIN YANG
}

A thesis submitted in partial fulfillment of the requirements for the degree of

\author{
MASTER OF SCIENCE \\ in \\ GEOGRAPHY
}

Portland State University 
TO THE OFFICE OF GRADUATE STUDIES AND RESEARCH:

The members of the Committee approve the thes is of Li-min Yang presented August 13, 1987.

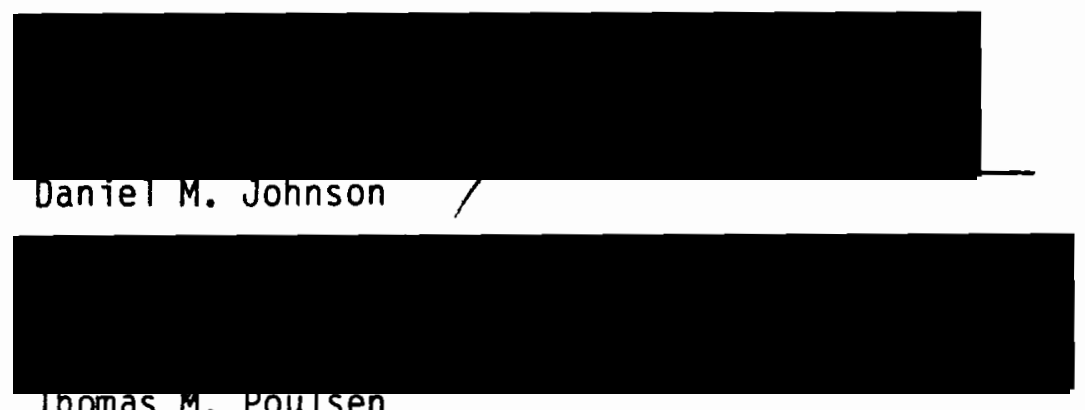

Thomas in. poulsen

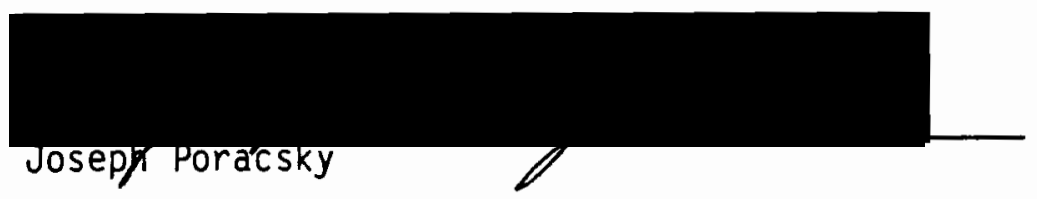

APPROVED:
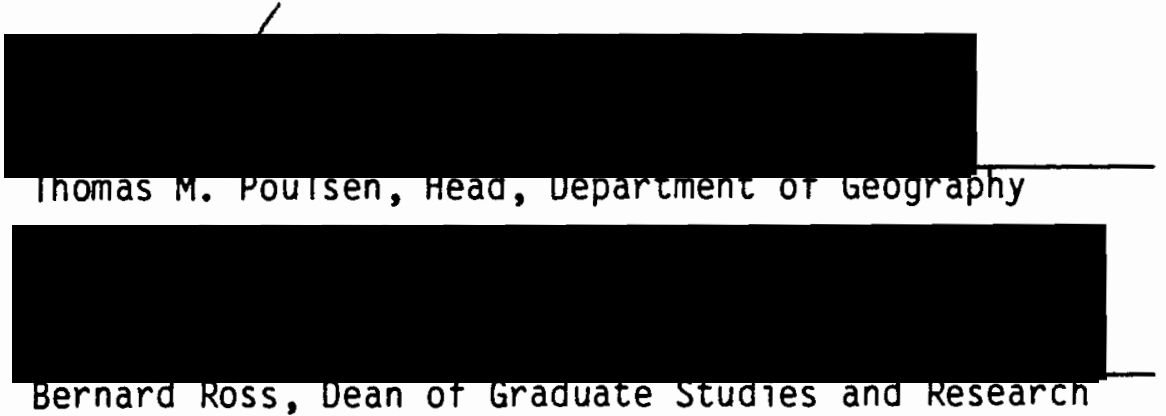


\section{ACKNOWLEDGEMENTS}

I wish to thank those people who helped make this thes is possible. Many thanks to Dr. Johnson, who encouraged and advised me from the beginning to the end of this project. Without his guidance, the study would not have been accomplished.

Very special thanks to Charles Ferris and the Bonneville Power Administration who generously provided temperature data for the Portland Metropolitan Area.

I would also like to thank all the faculty, staff, and fellow students in the Geography Department at Portland State for providing a friendly learning environment during my stay of two years.

Finally, thanks to my wife Zheng Zhang, my daughter Si-yuan, and the rest of my family for their patience and understanding during my study in the United States. 
TABLE OF CONTENTS

PAGE

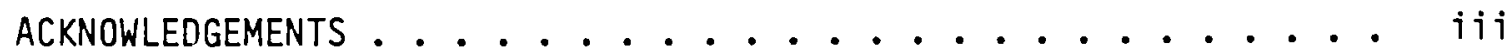

LIST OF TABLES ................................ vi

LIST OF FIGURES .................................... vii

CHAPTER

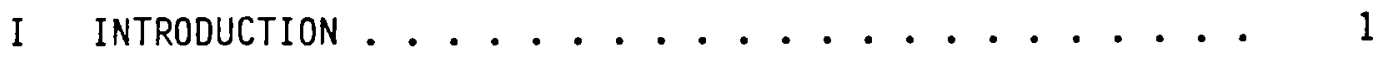

Purpose ............... . . 4

Review of Previous Studies.......... 6

The Data Base and Methodology ......... 12

Organization of the Thesis......... 18

II SPATIAL TEMPERATURE CHARACTERISTICS . . . . . . . 19

General Climatic Feature .......... 19

Weather Review of 1985 ......... . 23

Seasonal Temperature Distribution ...... 30

Impact of Weather conditions ......... 46

Summary ................ 71

III LONG-TERM TEMPERATURE VARIABILITY . . . . . . . 76

Global, Regional, and Local Temperature Trend . . 76

Temperature Variation and Control Factor..... 84 
CHAPTER

PAGE

IV DISCUSSION AND SUMMARY . . . . . . . . . . . . . 95

Summary of Results............... 95

Suggestions for Future Reseach . . . . . . . . 98

REFERENCES •. . . . . . . . . . . . . . . . . . . 100 APPENDIX . . . . . . . . . . . . . . . . . . . 108 


\section{LIST OF TABLES}

TABLE

PAGE

I Stations of Portland Mesoscale Weather Network. .....

II Climatological Stations for Long-term

Temperature Record ............. 16

III Climate Summary of Portland ............ 21

IV Seasonal Temperature Variation in the

Portland Area, 1985.............. .

$V$ Temperature Variation Under Clear Skies in the

Portland Area, 1985. . . . . . . . . . .

VI Temperature Variation Under West Wind in the

Portland Area, 1985..............

VII Temperature Variation Under East Wind in the

Portland Area, 1985...............

VIII Temperature Variation Under Overcast in the

Portland Area, 1985..............

IX Temperature Variation on Rainy Day in the

Portland Area, 1985.............. 70

X Mean Annual Temperature Trends, 1900-1984 ....... 81

XI Month1y Mean Temperature Trends for Northern Hemisphere and Portland, 1900-1984........... 
XII Linear Temperature Trends for Selected Stations

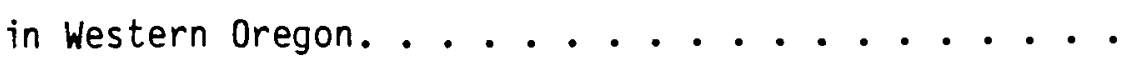

XIII Linear Trends of Temperature Difference Between Stations in Western Oregon................ 92

XIV Comparison of Urban Warminng Trends .......... 93

XV Comparison of Temperature between Bonneville Dam

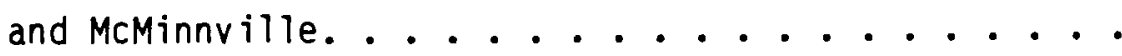

XI Comparison of Temperature Between Oregon Coastal

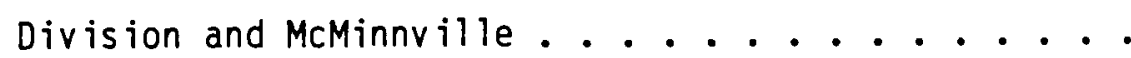




\section{LIST OF FIGURES}

FIGURE

PAGE

1. Topography of Portland and its Surroundings. . . . . . .

2. Portland Mesoscale Weather Network . . . . . . . . .

3. Generalized Air Pressure and Wind Conditions . . . . . . 20

4. Annual March of Daily Temperature in Portland, 1985. . . 24

5. $700 \mathrm{mb}$ Circulation Patterns in 1985. . . . . . . . . 26

6. Seasonal Mean Temperature of Portland, 1985. . . . . . 31

7. Seasonal Mean Maximum Temperature of Port1and, 1985. . . 35

8. Seasonal Mean Minimum Temperature of Portland . . . . . . 41

9. Temperature Distribution Under Clear Skies . . . . . . 50

10. Surface Synoptic Pressure Pattern for Typical Winds. . . 52

11. Temperature Distribution Under West Wind . . . . . . . 56

12. Temperature Distribution Under East Wind . . . . . . . 59

13. Temperature Distribution Under Cloud Cover . . . . . . 65

14. Temperature Distribution on Rainy day. . . . . . . . . 72

15. Time Series of Mean Annual Temperature Departures. . . . 79

16. Population Growth in Portland, Oregon, 1890-1980 . . . 85

17. City Expansion of Portland . . . . . . . . . . . 86

18. Schematic of Local Stations. . . . . . . . . . . 89

19. Evolution of Temperature Differences Between

Portland Downtown and McMinnville. . . . . . . . 91

20. The generalized pattern of the urban heat island in the Portland Metropolitan Area. . . . . . . . . 


\section{CHAPTER I}

\section{INTRODUCTION}

The study of urban climatology has been a source of human inquiry at various levels of sophistication ever since people began to congregate in cities. However, in recent years there has been an increasing effort to document local climatic change and the spatial distribution of climate elements affected by both physical characteristics and human activities. Generally, studies of urban climate fall into one of two categories. The first emphasizes the exploration of the physical processes, and involves the modelling of the radiation balance, the water and energy balance, the structure of boundary layers, and the urban heat island. The second category concentrates on temporal and spatial of the influential components on a series of climate elements. General reviews of the recent literature in this field are given by Oke $(1974,1979)$ and Atkinson (1985).

Most urban climate analyses have been for cities located in areas of relatively flat topography; thus the influence of topography could be negligible and the urban influence could be isolated (Hsu, 1979; Landsberg, 1979; Jones and Jiuto, 1980). However, as has been pointed out by Lowry (1977) and Landsberg (1979), an important issue regarding urban climate study is the fact that many cities are located in special topographic settings. Unless the climatic effects created by topography are so trivial that they can be ignored, the influence of local 
landscape should not be overlooked.

The unique geographic setting of Portland, Oregon, presents an opportunity to study the urban effect on local climate in a city with complex topography. So far, little research has been done on the spatial and temporal variation of temperature in a coastal city with complex topography. In addition, a comparison of long-term temperature change with the global, regional, and local scale has not been made for Portland; this is essential for understanding local climatic change and the urban $c$ limate.

The combination of controls that determine the climate of Portland is fairly complicated. First, Portland's temperate marine climate is primarily determined by its mid-latitude and west-coast location. Prevailing winds are westerlies which provide plenty of moisture, clouds and rainfall for Portland except in the summer.

Second, aspects of the topographic setting modify the regional climate. The Portland metropolitan area lies at the north end of the Willamette valley, with the Coast and Cascades Mountains on the west and east sides, averaging from 1,500 and 5,000 feet above sea level, respectively. The mountains are major barriers which influence the pattern of airflow and the temperature distribution over the entire area. More specifically, topographic relief is common with in the metropolitan area itself (Fig. 1). Rising steeply to the west of the city are the north-south trending Tualatin Mountains, commonly referred to as the West Hills. East of the Willamette River are a series of relatively flat, low-lying alluvial terraces, with a few 


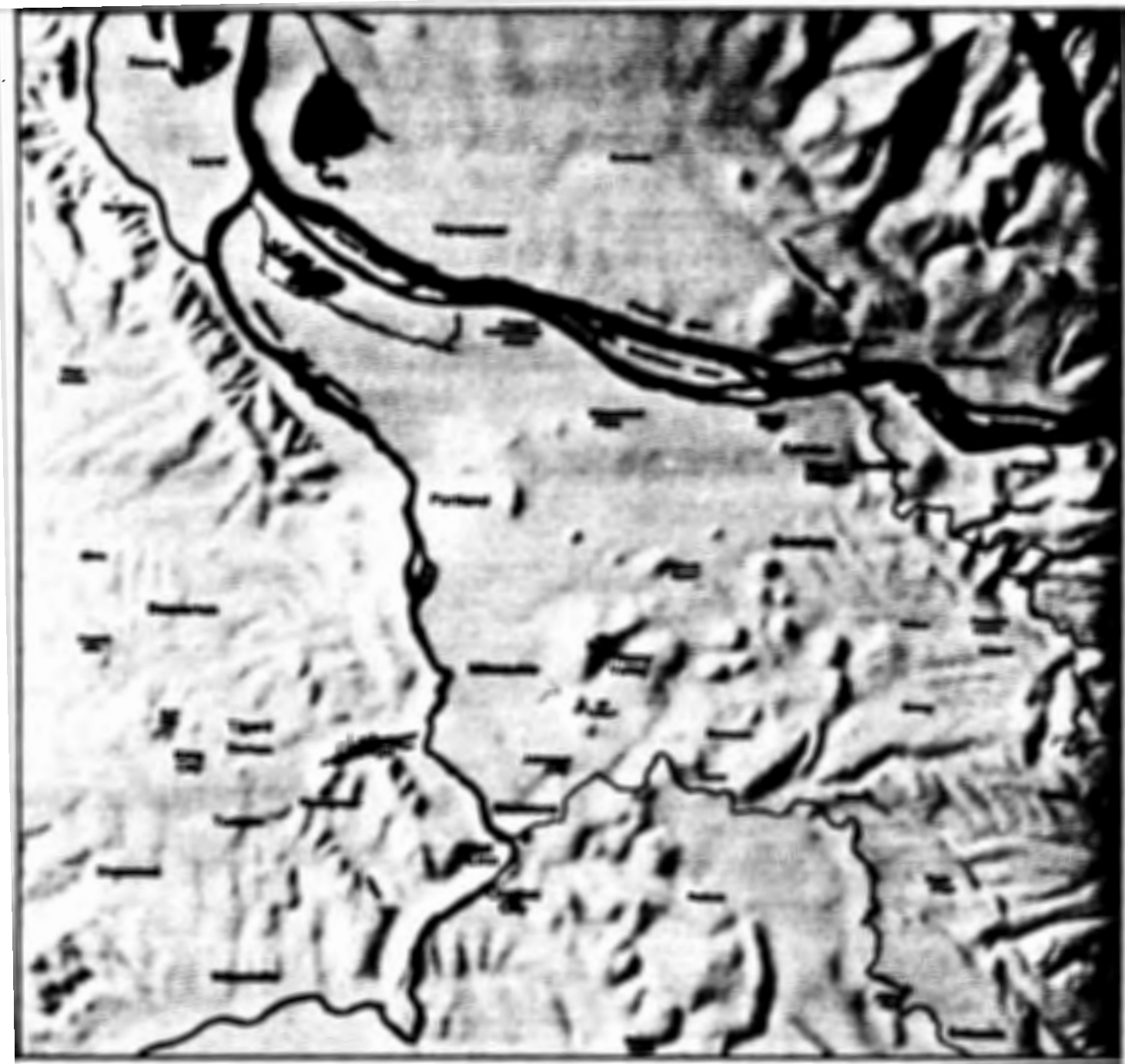

Figure 1. Topography of Portland and its surroundings. 
prominent erosional remnants rising above the lowlands to elevations up to 600 feet. All these features affect the spatial pattern of temperature and precipitation. The most significant influence on the city's temperature is, perhaps, the presence of the Columbia Gorge along the Columbia River, about 20 miles east of Portland. The Gorge exerts its impact on the local climate of both Portland and its suburban areas. Third, Portland has experienced widespread city expansion and population growth during the last century. Spatial expansion, with associated land-use conversion and industrial development, has altered the energy balance and water balance in the urban area.

\section{PURPOSE}

The primary purpose of this thes is is to analyze the spatial temperature pattern and the long-term temperature regime and its variation in the city of Portland and adjacent areas. Impact of urbanization, topography, and local weather conditions on temperature characteristics will be analyzed. Specifically, the following questions will be explored:

1. How does the spatial pattern of temperature vary under the combined influences of topography and different weather conditions?

2. Does an urban heat island exist in the Portland metropolitan area? If so, what are its basic features and temporal variations?

3. To what extent has the long-term temperature trend in Portland varied from its surroundings during the last century? How are these temperature fluctuations influenced by global and/or regional climatic change, and by urbanization? 
Several major factors and their influence on characteristics of Portland's temperature need to be analyzed. First, there are only a few references available related to the impact of topography on temperature patterns in Portland. For instance, the temperature distribution is found to correlate with elevation in some places; however, some low-lying areas have exceptionally cold nights due to the impact of cold air drainage (Wantz, 1983). This indicates that the spatial temperature field can be affected by more than one factor. In different locations and different seasons, the relative influence of the various controls may vary substantially.

Second, it is necessary to study the effects of different weather conditions on seasonal and diurnal temperature variations, because the synoptic conditions change distinctively with the seasons and even during a day. For instance, under the influence of high pressure in eastern Oregon, continental air moves into Portland through the Columbia Gorge. In the fall this creates warm and dry 'East wind weather', while in the winter Portland gets more than its share of transition weather such as freezing rain (Johnson, 1981).

Third, there exists little quantitative information about the urban heat island in Portland. Steve Johnson (1981) reported, for example, that the temperature at night in downtown Portland may be $10^{\circ}$ to $15^{\circ} \mathrm{F}$ warmer than in Beaverton, west of the Tualatin Mountains. This suggests that the Tualatin Mountains, with an elevation of more than 1,000 feet, do have a significant impact on temperature. Therefore, a more detailed study of Portland's heat island effects, its distribution, and seasonal variation is needed to understand the city's climate. 


\section{REVIEW OF PREVIOUS STUDIES}

The body of literature on urban climatology is large, but the majority of it deals with the urban heat island. Generally, the literature regarding the urban heat island can be separated into two categories. One type of research involves modelling of the urban climate by introducing either empirical formulae or physico-mathematical simulation techniques. These types of studies have been done by Myrup (1969, 1972), Oke (1972), Tapper et a1. (1981), and Atkinson (1983).

A typical study of this type was conducted by Myrup in 1969 and his work inspired many of the subsequent studies. He presented an energy budget model to study the heat island effect in terms of solar radiation, latent heat of vaporization, sensible heat and soil heat flux. When this model is applied to different surfaces which have different responses to radiation, the resultant surface temperatures are varied. Another modelling approach is to use an empirical model to determine heat island intensity $d t_{u-r}$ (maximum urban-rural temperature difference), and relate it to city population, city size, wind speed, vertical lapse rate temperature, and rural potential temperature gradient. It was found the $\mathrm{dt}_{u-r}$ is proportional to the logarithm of the population (Oke, 1976), and a substantial amount of the variance of temperature rise in cities could be explained by a function of population growth.

The influence of wind on the heat is land effect was documented by Oke and Hannell (1970) who gave the limiting wind speed for occurrence of the heat island. Ludwig (1970) established a linear relation between the magnitude of the nocturnal urban-rural temperature differences and 
the vertical lapse rates. It has also been found that atmospheric stability and wind speed affect the heat or cold island intensity through their influence on the vertical transfer of heat from the urban and rural surfaces by turbulence. Lee (1979) and Nkemdirm (1980) reported that the urban heat island intensity relates to the lapse rate of the rural area and the horizontal windspeed. These results, overall, are agreeable with the generally accepted idea that stability favors the formation and persistence of an urban heat island, whereas instability does the reverse. Similarly, calms and low windspeeds are likely to support urban temperature anomalies, while high air speeds create an opposite effect.

More recently, dynamic modelling has been employed to simulate and predict the urban heat island. This approach essentially involves the specification of relationships between energy exchange, forces acting upon the air mass, and the acceleration of wind and airflow. Given an initial condition of temperature and airflow, future values of these parameters can be calculated (Atkinson, 1985).

A second category of research on the heat island uses an observational approach. It is concerned with distribution, intensity, temporal change and the contributing environmental factors of the urban heat island.

A major effort and probably the most intense study of urban weather processes was made in project METROMEX at St. Louis (Changnon et al., 1977; Ackerman et a1., 1978 and others). Among many other results, the St. Louis summer afternoon heat is land was measured at 2.7 to $6.3^{\circ} \mathrm{F}$ (Auer, 1978). Similarly, in the city of Chicago the urban-rural 
temperature differences range from 0.7 to $6.1^{\circ} \mathrm{F}$ with an average of $3.2^{\circ}$ F (Ackerman, 1985). Many other similar results have been reported from cities in different parts of the world.

Studies of diurnal, weekly, and seasonal changes in the urban heat is land and urban-rural cooling rates have been done by Oujezdsky (1973), Nkemdirim (1977) and others. As a summary, Oke (1973) reviewed previous works of other researchers and stated that the maximum heat is land usualiy appears 3-5 hours after sunset. Afterwards, the temperature difference between urban and rural areas declines towards morning. The reason for the appearance of the maximum temperature difference is due to a very strong rural cooling effect. He also suggested that seasonal changes relate to climatological and vegetational changes as well as anthropogenic activities, and that annual variations reflect the impacts of urbanization.

Nkemdirm (1980) reported the effect of cold air drainage on the magnitude of the urban heat island in Calgary, Canada. He found that cold air drainage can significantly reduce the magnitude of the urban-rural temperature anomaly and that it contributed substantially to an increase in the depth of the temperature inversion observed over the city center.

Some studies discuss the relevance of land-use to temperature distribution. August (1977) studied the correlation of land-use and vegetation cover with temperature anomalies. He took the percentage of vegetative cover as a characteristic of the land-use distribution, and identified temperature anomalies related to the land-cover characteristics in the St. Louis area. However, he mentioned that the 
interactive and feedback processes between land-use type and temperature anomalies have not been clearly understood.

White (1978) also examined urban land-use and temperature fields from an energy process point of view. His results indicated that distinct differences are seen in reflected solar radiation, emitted radiation, and net radiation between the urban and rural land-use types. Generally, these different patterns of net radiative components showed some correlations with the amount of vegetative coverage within each land-use.

Alternatively, Unwin (1980) used the method of synoptic climatology to analyze the heat island of Birmingham, UK. He used temperature data from $c$ limate stations in the area as well as stratified weather types. Through statistical analysis he found that especially during spring and autumn the heat island is a quite substantial feature under settled anticycionic conditions.

The long-term temperature regime and its variation in urban environs has been studied by Landsberg et al. (1979), Hsu (1979), Jones and Jiuto (1980), Zhou (1983) and others. The methodology used in these studies was an examination of the historical data from climate stations in the urban area, supported by control stations in surrounding rural or non-urban areas. In addition, the temperature trends and correlation of temperature with urban non-climate data (e.g., the increase of automobiles, the amount of pollutants, population growth) are often compared to reveal the possible reasons for long-term temperature variation. Statistical techniques such as time-series analysis, spectrum analysis and regression are major tools used. 
Hsu (1979) examined the effects of urbanization on the climate in an arid area--Phoenix, Arizona. He found that the temperatures in the winter season at the city center are significantly higher than at the surrounding rural sites. For example, during the past 50 years the winter minimum temperature has increased from $37^{\circ}$ to $41^{\circ} \mathrm{F}$ at the Phoenix City center, as opposed to a slower rise from $32^{\circ}$ to $34^{\circ} \mathrm{F}$ in the rural areas. Zhou (1983) studied the influence of urban development on temperature in Shanghai, located in a subtropical monsoon climatic region. She found that the annual temperature differences between Shanghai urban and rural areas had increased about $0.6-0.7^{\circ} \mathrm{F}$ in the past twenty years. Similar studies were reported in many other cities.

One significant purpose for the study of long-term temperature variability is to assess the urban effects on temperature variation so that the regional and global temperature varibility can be identified. Cayan and Douglas (1984) stressed that a severe problem in assessing the level of variability associated with natural and human influence on climatic change is that a significant portion of the monitoring stations are situated in densely populated industrial centers. Consequently, the temperature is often biased by urban heat island effects. Accordingly, some efforts have been made recently to study global, regional, and local long-term temperature variation and their interaction.

Many papers have been published regarding temperature trends in the northern hemisphere over the past century (Mitche11, 1961, 1963; Barnett, 1978; Jones and Kelly, 1983; Jones et al. 1986). There is general agreement that hemispheric warming occurred between about 1880 
and 1940, followed by cooling which continued until 1960. As to the latest warming trend, which started since the mid-1960's, there is some disagreement among the researchers.

Among others, Jones, et al. (1982) used monthly world and CLIMAT network data in the analysis of northern hemisphere temperature patterns. They found a general warming trend beginning in the early $1900^{\prime}$ 's and lasting to the late 1930's. A general cooling period followed and continued until the 1960's. During the post-1960's warming period, winter and spring temperatures indicate the initiation of warming in the mid to late 1960 's, while autumn data suggest a warming trend beginning in the mid 1970 's. Summer data show an even more recent initiation of a warming trend (Jones et al. 1982, p. 68). In 1983 Jones and Kelly identified three general trends in the northern hemisphere between 1901-1980: warming between 1917-1939, cooling between 1940-1964, and warming from 1965 to the present. Jones et a1. (1986) found, using homogenized and extended data, that a slight cooling trend prevailed from about 1875-1885, a rapid warming trend began in about 1920 and peaked in the late 1930 's, and a definite cooling trend appeared in about 1930 and lasted until 1965 when the general warming trend resumed. There is scant information concerning long-term temperature variability for Portland. No study has been made of the comparison between local temperature pattern and regional and global ones. There are several investigations of regional climatic change in western and northwest United States (Carter, 1935; Church, 1954; Hubley, 1956; Coakley, 1979; Johnson and Dart, 1982). Among others, Roden (1966) studied regional temperature fluctuations in the western United States 
for the period 1821-1964. Monthly mean and extreme records in California, Oregon and Washington were analyzed. He concluded that there is no evidence of any secular (period of instrumental records) air temperature changes in natural (rural and small town) enviroments over the past century. In large cities, however, the temperature has increased substantially. Proxy data at Longmire, Washington, were studied by Graumlich and Brubaker (1986). They reconstructed the long-term mean annual temperature (1590-1980) from tree ring records, and identified three well developed trends in the past century. A short period of declining temperature occured from about 1870 and continued until about 1880. Following this, a long warming trend persisted until late 1930 's, with cooling from 1940 to the present.

\section{THE DATA BASE AND METHODOLOGY}

The Data Base

Spatial and Short-Term Variation of Temperature. Recent local temperature records collected by the Portland Mesoscale Weather Network set up by Bonneville Power Administration (BPA) will be used for this part of the study. This network covers approximately 2,500 square miles. It extends from the eastern foothills of the coastal mountains on the west to the foothills of the Cascade mountains on the east, and from Woodland, Washington, in the north to Woodburn, Oregon, in the south (Wantz, et al. 1983). There are now five-year-long temperature records from 1981 through 1985, including maximum and minimum temperature on a daily basis. The basic information for these sites is given in Table $I$ and depicted in Figure 2. 


\section{TABLE I}

\section{STATIONS OF PORTLAND MESOSCALE WEATHER NETWORK}

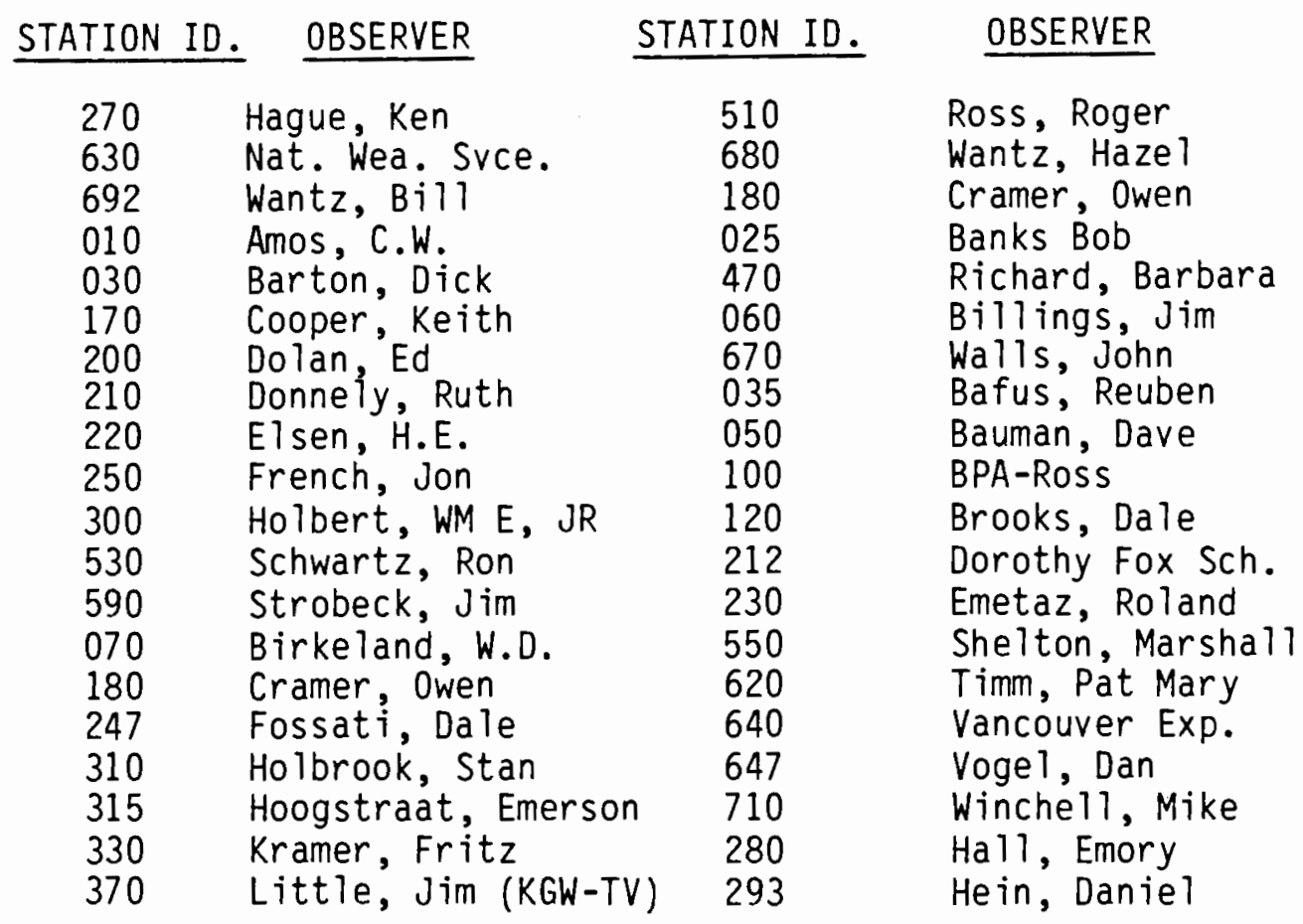

Source: Bonneville Power Administration (BPA), 1980.

In addition to temperature data, data on different weather conditions in four seasons are necessary. These data are available from Local Climatological Data published by the National Oceanic and Atmospheric Administration (NOAA) and will be analyzed to determine the influences of meteorological conditions on temperature behavior. Also, topographic maps, land-use maps of the Portland metropolitan area and other pertinent sources of information will be consulted. 


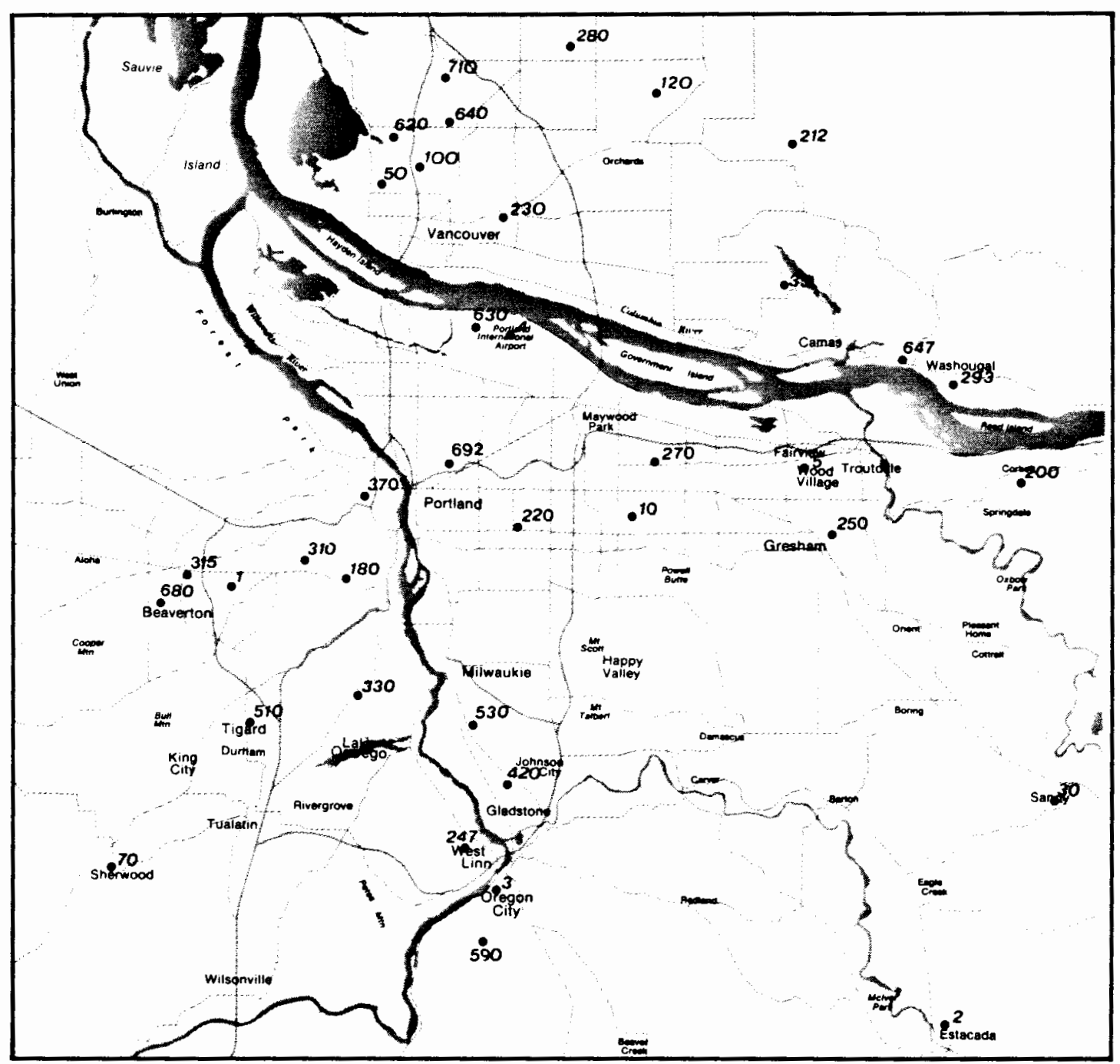

Figure 2. Portland mesoscale network. Only stations recording daily temperature are included. (Data from BPA.). 
Long-Term Temperature Regime and Its Variation. Five long-term

climatological temperature series have been selected for this portion of the study. Three of these are station records from the willamette Valley, i.e., Portland Downtown, Portland international airport, and McMinnville. The fourth is the station record at Bonneville Dam, located at the mouth of Columbia Gorge where temperature is strongly affected by local airflow. The fifth data series is that of the oregon coastal division, an average of all stations with in the coastal reporting division which extends from Astoria in the north to Brookings in the south. As most stations in the coastal region are located in flat area and small towns, presumably they are least influenced by urbanization and topography and thus represent the regional trend. The locations and elevations of all five stations are listed in Table II. The length of record for these stations ranges from 45 to more than 90 years. The parameters of temperature chosen for study are the monthly maximum, min imum and mean.

Although metric units have long been the standard language of scientists, the voluminous climatic data for the United States are available primarily in English units. In this thesis, the English units are used throughout. Some information quoted from other sources in which the metric system was used are converted into English units.

\section{Methodology}

Spatial and Short-Term Temperature Variation. For study of short-term temperature variations and the urban heat island, the maximum, minimum, and the range of temperature will be computed on a seasonal and monthly basis, and then plotted individually. Two aspects 
will be identified by this process. One is to see the seasonal and diurnal changes of temperature in the Portland metropolitan area; the other is to depict the features of the spatial temperature distribution and the heat island effect at a certain season or month by comparing urban temperature with rural temperature.

\section{TABLE II}

CLIMATOLOGICAL STATIONS FOR LONG-TERM TEMPERATURE RECORD

$\underline{\text { ID }}$

026749

026751

020897

025384
Name

Portland KGW TV

Portland WSFO

Bonneville Dam

McMinnville latitute longitude

$45^{\circ} 31^{\prime}, 122^{\circ} 41^{\prime}$

$45^{\circ} 36,122^{\circ} 36$,

$45^{\circ} 38,121^{\circ} 57$

$45^{\circ} 14^{\prime} 123^{\circ} 11$

elevation

$159 \mathrm{ft}$.

$21 \mathrm{ft}$.

$60 \mathrm{ft}$.

$148 \mathrm{ft}$.

* The mean temperature of thirty-one stations in Oregon coastal region.

To study the influence of weather conditions on temperature, synoptic types will be selected and examined to identify the relationship between each weather condition and the spatial temperature distribution. Samples of these weather conditions are chosen from different seasons. In this way, a relatively complete picture of short-term temperature variation will be gained.

Long-Term Temperature Trend Analysis. The magnitude of the temperature reading, $T$, at a particular station and at a certain time is essentialiy composed of three parts. This can be expressed in a simplified form:

$$
T=t_{r}+t_{\eta}+t_{h}
$$

where, $t_{r}$ is the temperature by influence of global and regional climate; $t_{1}$ is the temperature by influence of local landscape; $t_{h}$ is 
the temperature by influence of human activities (e.g., urbanization process).

This framework is generally applicable for analysis of long-term temperature data. As was discussed in the early part of the chapter, if a city is located in an area with relatively complex topography the second term in formula (1), $t_{\eta}$, becomes one of the important components of temperature value. Hence, for the study of Portland's long-term temperature, all three components in formula (1) should be analyzed individually.

It is necessary to understand, first, the global temperature trend over the study period. This will be accomplished by analyzing temperature fluctuations in the northern hemisphere. To illustrate the regional temperature trend, data from the coastal division and McMinnville in the Willamette Valley will be examined. As mentioned previously, the reason for selecting these stations to represent the regional trend is that they are least influenced by urbanization. Moving averages and linear regression are used to analyze the data.

The influence of topography, especially the Columbia Gorge and the Coast Range, on local temperature must be analyzed. The method for pursuing this question is to compare two pairs of climate stations in non-urban locations with different sites. In this way, influences of urbanization can be ignored and the impact of local landscape on temperatures identified; i.e., of the three terms in formula (1), $t_{r a}=t_{r b}$, and $t_{h a}=t_{h b}=0$ (the subscripts $a$ and $b$ represent the two stations to be compared), then, the difference between $t_{1 a}$ and $t_{1 b}$ will be attributed to the influence of local landscape. 
Once the global and regional climatic trends and local landscape influences on temperature records are understood, the effect of urbanization on Portland's long-term temperature can be determined by removing the large scale temperature trends. The result could be considered as the "real temperature trend" caused by urbanization.

\section{ORGANIZATION OF THE THESIS}

The remaining chapters of the thesis are organized as follows: Chapter II will discuss the topics of temperature distribution and the urban heat island in the Portland metropolitan area, including a presentation of seasonal temperature changes. Then, the effect of different weather conditions on temperature patterns will be presented.

Chapter III is composed of the discussion of global, regional and local temperature changes, the analys is of temperature trends of Portland and its surrounding stations, and temperature variability in urban and non-urban areas.

Chapter IV is the conciusion of the research, including a summary of the results and suggestions for future research. 
CHAPTER II

SPATIAL TEMPERATURE CHARACTERISTICS

\section{GENERAL CLIMATIC FEATURES}

The climate of Portland--a modified west coast marine type--is primarily determined by its geographic location, the general atmospheric circulation patterns, and the local topography. The geographic location $\left(45^{\circ} 31^{\prime} \mathrm{N}, 122^{\circ} 41^{\prime} \mathrm{W}\right)$ accounts for the seasonal variation of climate and the dominance of the prevailing westerlies. Also, Portland's proximity to the Pacific Ocean is responsible for a marine influence on the climate, especially on temperature and precipitation patterns.

The atmospheric circulation itself is the most direct control on weather and climate in a given region. Trewartha (1981) pointed out that a well-defined annual cycle of precipitation and temperature in Portland is closely associated with the seasonal migration of the North Pacific subtropical high pressure cell, the jet stream, and associated cycionic storms (Fig. 3).

Local topography plays a significant role in shaping the climate. In Portland, the major topographic influence on climate is caused by nearby mountains and hills. To the west of the city, the Coast Range is both a buffer protecting Portland from the full impact of Pacific storms and a modifier of incoming air masses (Johnson, 1987). To the east of Portland, the higher Cascades function as a divide for climate between western and eastern Oregon, restricting, in general, marine air masses 
to the west and continental air masses to the east.
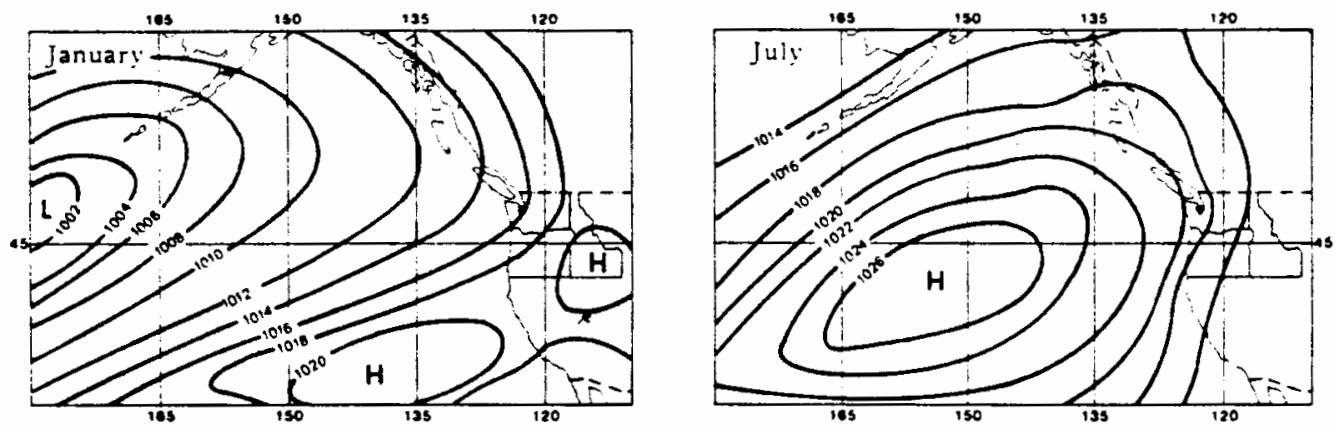

Figure 3. Generalized air pressure and wind conditions. From Jackson, 1985.

Temperature. Annual, seasonal, and diurnal temperature characteristics of west coast stations are strongly affected by maritime airflow from the Pacific Ocean. This accounts for the small amplitude of the diurnal and seasonal temperature variation as compared to east coast sites at the same latitude. In Portland, the mean temperature of the coldest month, January, is $38.9^{\circ} \mathrm{F}$. The warmest month is July, with a mean temperature $67.7^{\circ} \mathrm{F}$ (Table III). Hence, the annual range is $28.8^{\circ} \mathrm{F}$. The diurnal range of temperature is also small, especially in winter time, with a mean daily maximum in January of $44.3^{\circ} \mathrm{F}$ and a mean daily minimum of $33.5^{\circ} \mathrm{F}$. The mean annual temperature of Portland is $53.0^{\circ} \mathrm{F}$.

As to the temperature extremes, the lowest temperature recorded to date is $-3^{\circ} \mathrm{F}$, in February 1950, while the highest temperature was $107^{\circ}$ $\mathrm{F}$ recorded in July 1965. However, temperatures both below $0^{\circ} \mathrm{F}$ and above $100^{\circ} \mathrm{F}$ are very rare in Portland. Hence, combined with moist conditions, the climate of Portland is generally perceived as pleasant. Precipitation. Precipitation in Portland averages 34.7 inches 


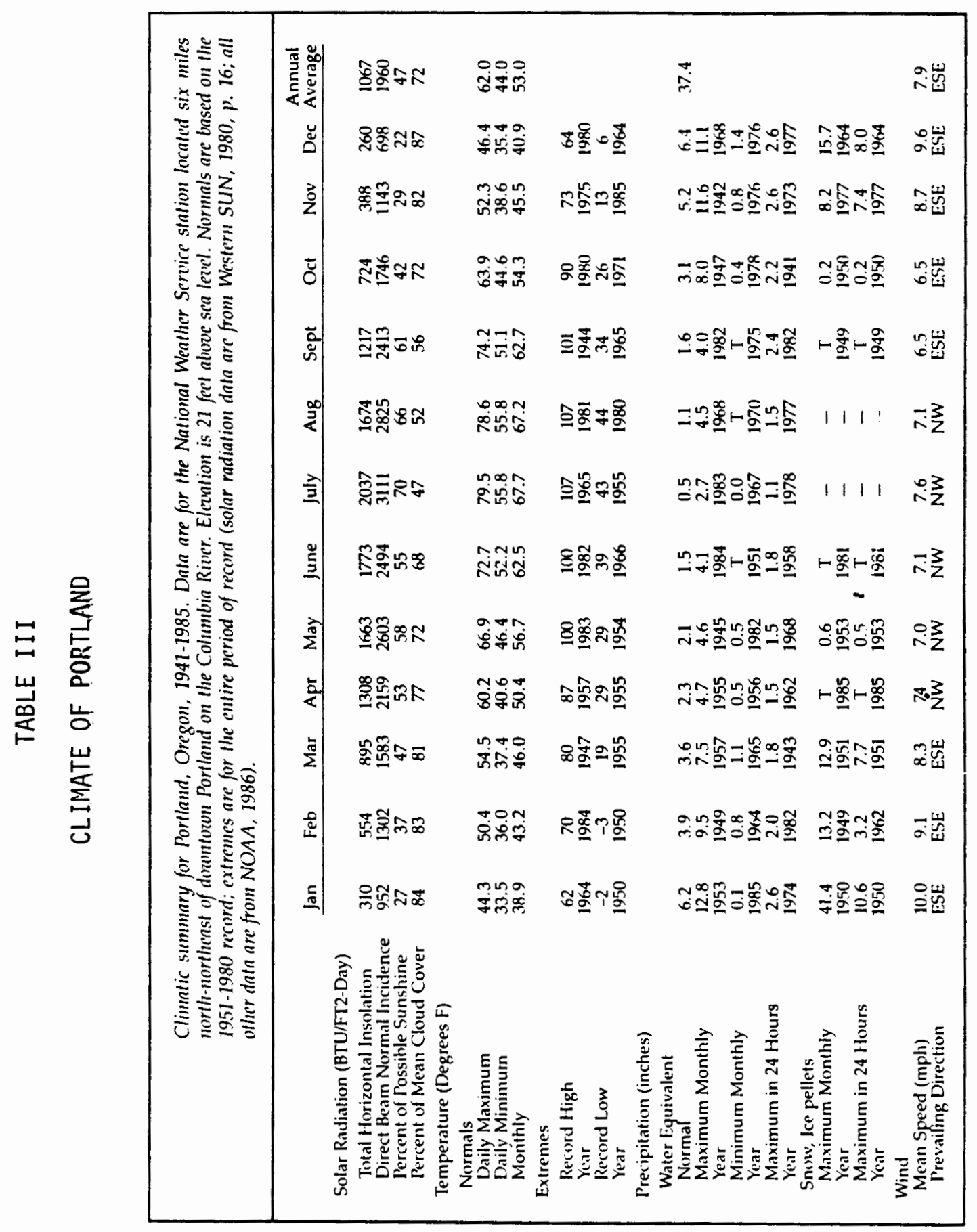


annually, with approximately 88 percent falling during the months october through May. The rainy season is associated with the cyclonic storms embedded in the westerly flow of maritime airstreams. The summer season is relatively dry due to the northward migration and control of the North Pacific High. Total precipitation from June through August is on ly 3.1 inches as opposed to an average of 16.5 inches in the winter season from December to February.

The spatial pattern of precipitation in the metropolitan area is dominated by the complex topography. Generally, a valley on the lee side of the hills is drier than the windward side. Consistent with the direction of prevailing west to southwest winds in the rainy season, the annual precipitation pattern shows a west to east gradient, a steady decrease down the east slope of the Coast Range and a steady increase up the west slope of the Cascade foothills (Wantz et al., 1983).

Surface Air Flow. In Portland, the general surface airflow is different from the upper level atmospheric winds because of the significant influence of local topography and the Columbia Gorge. Under the control of different surface pressure patterns throughout the year, the general surface airflow changes substantially with the seasons. The prevailing wind in the colder season, September through March, is east-southeast, as opposed to a dom inant northwest wind for the rest of the year. Winds are usually stronger during the cold months than during the warmer months due to the impact of the Gorge; maximum winds occur in January, with a mean speed $10 \mathrm{mph}$. 
WEATHER REVIEW OF 1985

Climate data have been collected by the Bonneville Power Administration (BPA) since 1965. This network was established to collect precipitation data. It now consists of 90 observation sites, some of which have also been observing and recording daily temperature since 1981. Between 1981 and 1985, several more stations were added to the temperature network bringing the total number to 37 . Among the temperature records available, the data for calendar year 1985 is the most complete; therefore, these data were used in the following analysis. Since the uneven distribution of the observation sites, gap of temperature record is found in area near the confluence of the Willamette and Columbia Rivers. To interpolate the isotherms, data collected by a series of temperature transects in the region are referenced. It was found that temperature gradient is essentially even over the area.

In 1985, many long-term daily temperature records were established throughout the United States due to persistent anomalies in the atmospheric circulation. In Portland it was also a rather unusual year in terms of climate (Fig. 4). To better understand Portland's spatial temperature characteristics, a review of regional circulation patterns in 1985 and their impact on temperature behavior follows.

From December 1984 through February 1985, the regional atmospheric circulation pattern was characterized by persistent pressure anomalies over North America. A high pressure ridge over the Pacific Northwest allowed cold air to enter the region from the north (Fig. 5-1). Under the influence of this atmospheric pattern most of Canada and the western 
United States experienced below normal temperature (Kousky, 1985). Portland also experienced a severe winter. Well below normal temperatures occurred in January and February, and the monthly departure from normal exceeded $2^{\circ} \mathrm{F}$ in both months (NOAA, 1986).

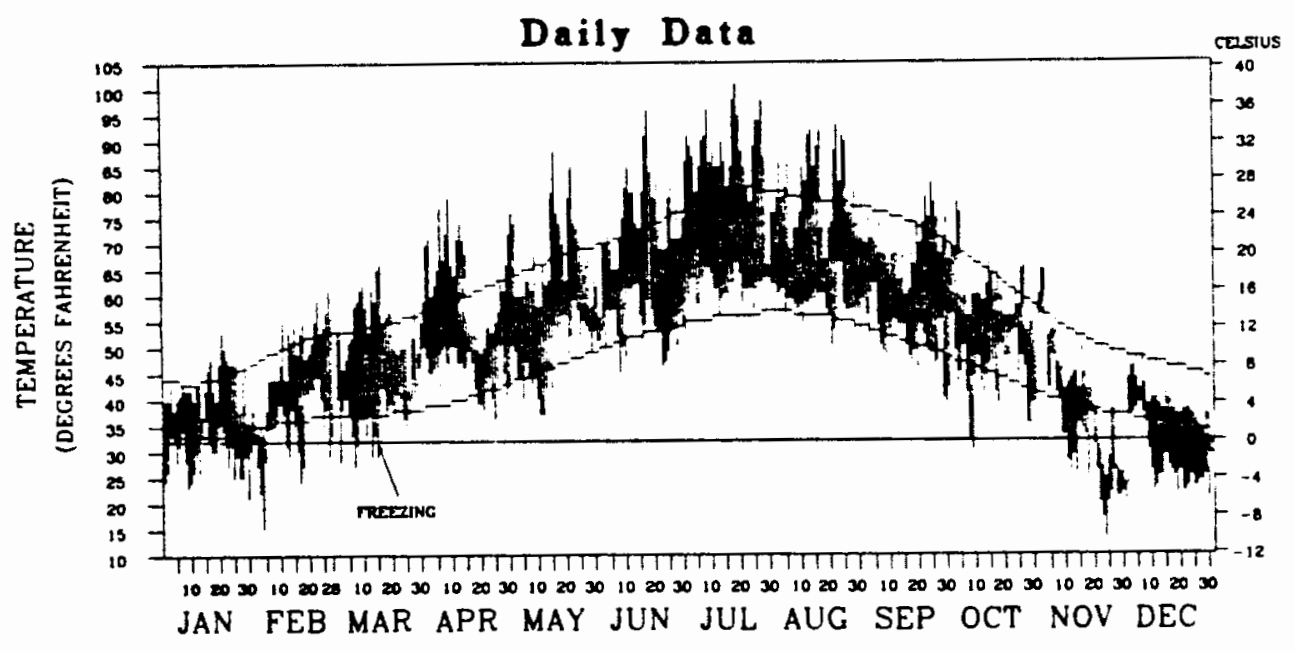

Figure 4. Annual march of daily temperature in Portland, 1985. Two curves represent the average daily maximum and minimum. (From NOAA. 1986).

The circulation pattern during the three months of spring (March-May) was marked by a distinct contrast between high and low latitudes. Below normal pressure heights in high latitudes as opposed to above normal heights at low latitudes led to a fast westerly flow at midlatitudes (Fig. 5-2). The presence of this flow was not conducive to the intensification of Arctic highs, thus preventing cool air from moving into the United States. Consequently, most of the nation had above normal temperatures (Wagner, 1986). Portland experienced higher than normal temperatures except in March. Temperature was $3.5^{\circ} \mathrm{F}$ above normal in April and $1.6^{\circ} \mathrm{F}$ above normal in May.

Summer 1985 (June-August) featured rapidly changing circulation 
patterns (Fig. 5-3). A ridge over the western United States developed in July and moved northward into southwestern Canada. This pattern resulted in mean temperatures well above normal in the northwestern states.

A reversed pattern over the northern states appeared in August as compared to the previous month. At $700 \mathrm{mb}$, weak negative departures over the northwestern states and weak positive anomalies in the northeast resulted in temperature considerably below normal in some of the northwestern and north central states (Bergman and 0'Lenic, 1986). In Portland, the temperature was above normal during the summer months, especially in July when the monthly temperature reached $74.1^{\circ} \mathrm{F}$ (normal $=67.7^{\circ} \mathrm{F}$ ); this was one of the warmest months of the century.

In the fall of 1985 (September-November), much of the northwestern United States experienced severe cold weather due to abnormally intensified troughs and ridges over the entire northern Hemisphere (Fig. 5-4). As strong ridges developed in southern Alaska, stronger than normal northerly flows brought cold air to the northwestern United States (Chen, 1985). The seasonal mean temperatures were from $5.5^{\circ}$ to $11^{\circ} \mathrm{F}$ lower than normal. In Portland, temperatures well below normal occurred in November. The monthly mean was on $1 y 37.3^{\circ} \mathrm{F}, 8.2^{\circ} \mathrm{F}$ below average. There were many days during the month when the temperature was below freezing. 


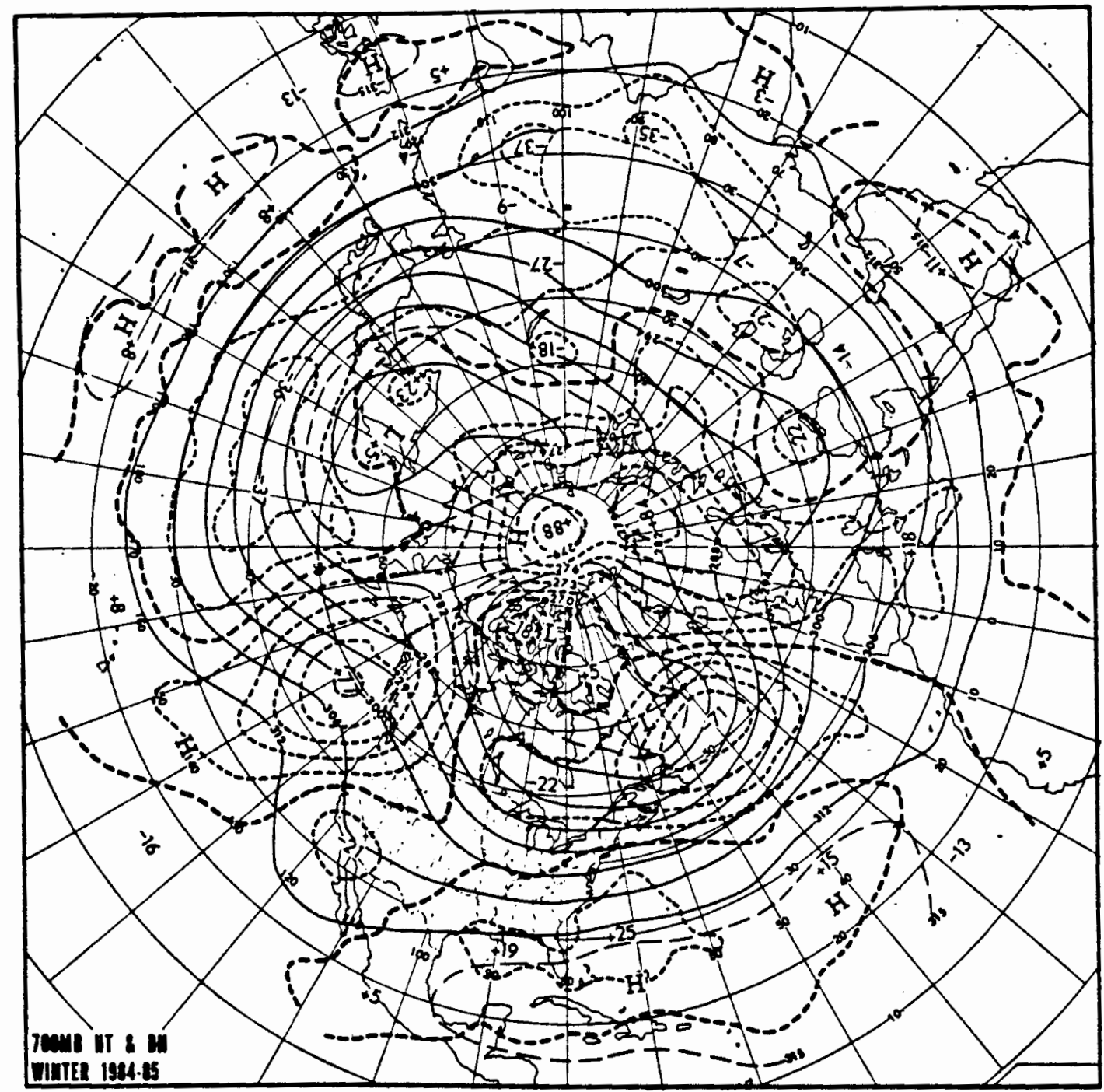

Figure 5-1. Mean $700 \mathrm{mb}$ (tens of meters, solid lines) and its departure from normal (meter, dashed lines) for winter 1984/1985. From Kousky, 1985. 


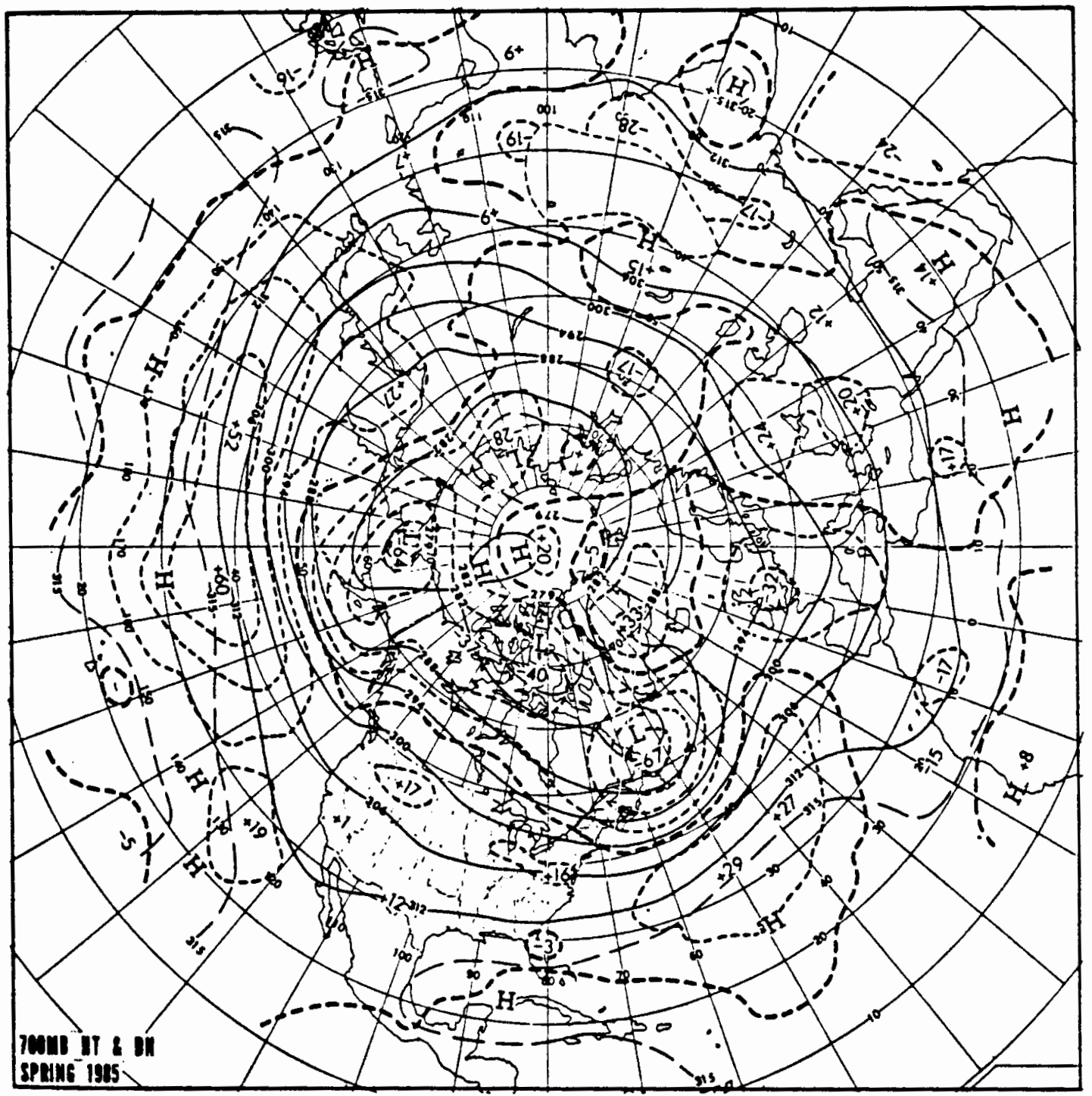

Figure 5-2. As in Figure 5-1 except for sping 1985. From Wanger, 1986. 


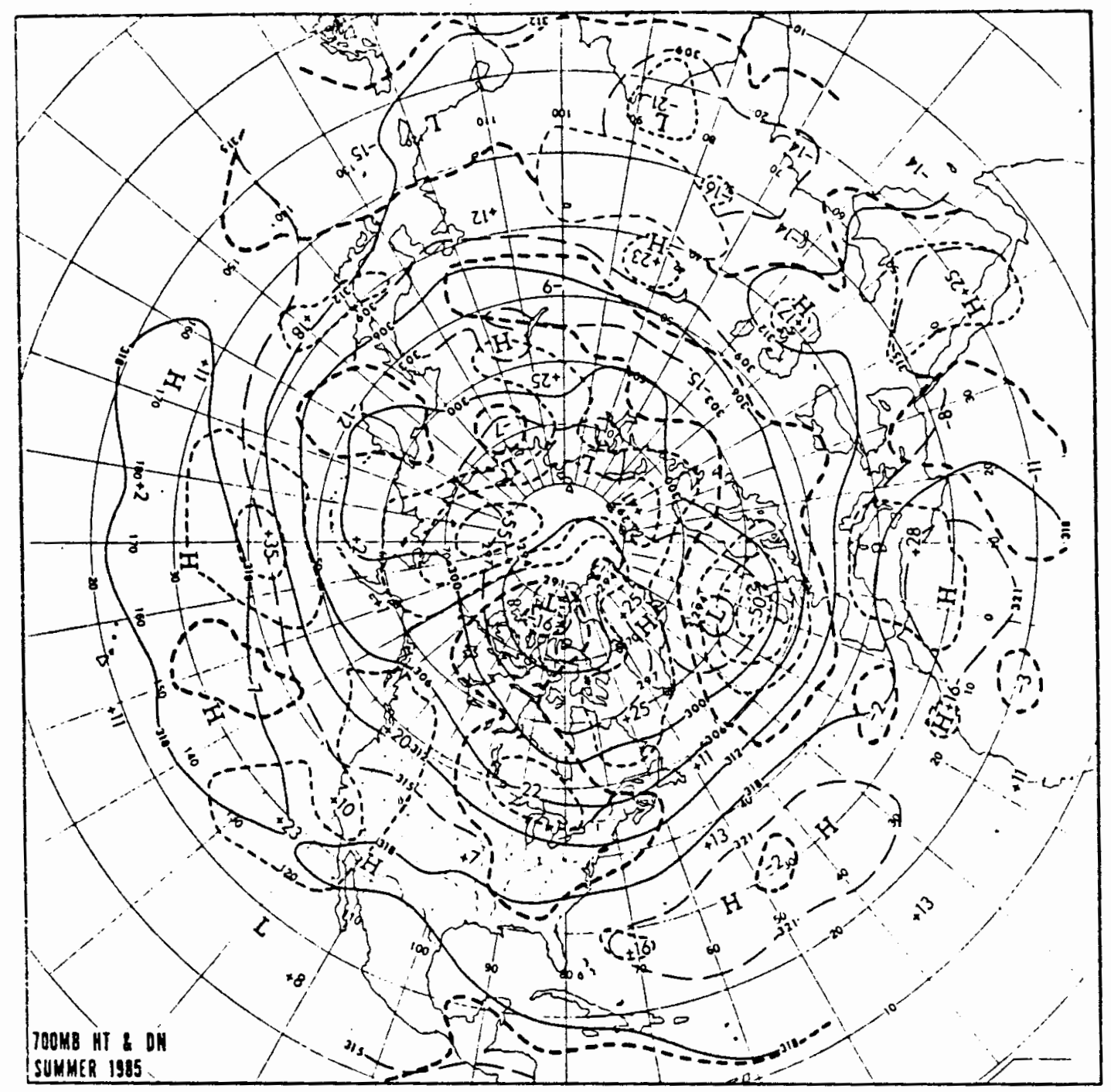

Figure 5-3. As in Figure 5-1 except for summer 1985. From Bergman and orienic, 1986. 


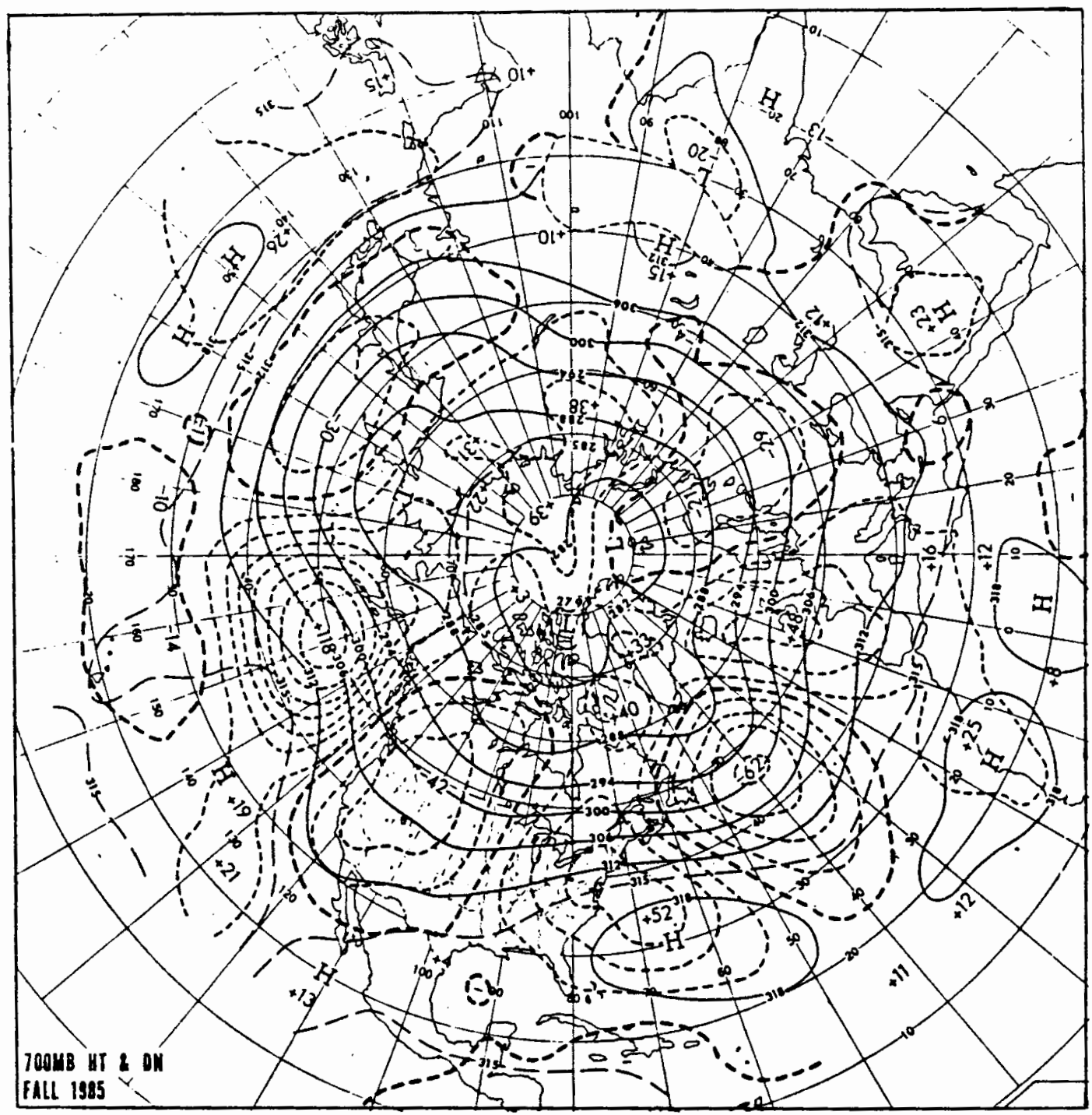

Figure 5-4. As in Figure 5-1 except for fall 1985. From Chen, 1986. 


\section{SEASONAL TEMPERATURE DISTRIBUTION}

\section{General Features}

The spatial pattern of temperature throughout the metropolitan area was fairly consistent in all seasons, especially for seasonal mean and max imum temperatures (Figs. 6,7). The highest temperature generally occurred in two areas--from east Portland to Gresham, and northwestward into Vancouver, Washington. The reasons for this pattern are clear: these areas are situated in the Portland Basin at a low elevation compared to the hills on both sides. In addition, they lie within the urban zone and the impact of urbanization on microclimate exists.

There is a cool region found in all seasons along the West Hills, extending southeast past Lake 0swego. This c0ol area is essentially caused by topographic features and vegetation cover on the hills at elevations from 500 to more than 1000 feet. Considering the normal condition of the lapse rate, the temperature at these higher elevations would be 3 to $4^{\circ} \mathrm{F}$ lower than that of downtown Portland.

In the Tualatin Valley southwest of Portland, the topography is characterized by relatively low land (below $500 \mathrm{ft}$.) with some small hills. Temperature is generaliy higher in the southwest and lower in the northeast of the valiey, and the isotherms extend from northwest to southeast, in agreement with the orientation of the West Hills and the main ax is of the valley. The dominant control on temperature distribution in the valley is the elevation, as can be seen from the direction of the temperature gradient. 


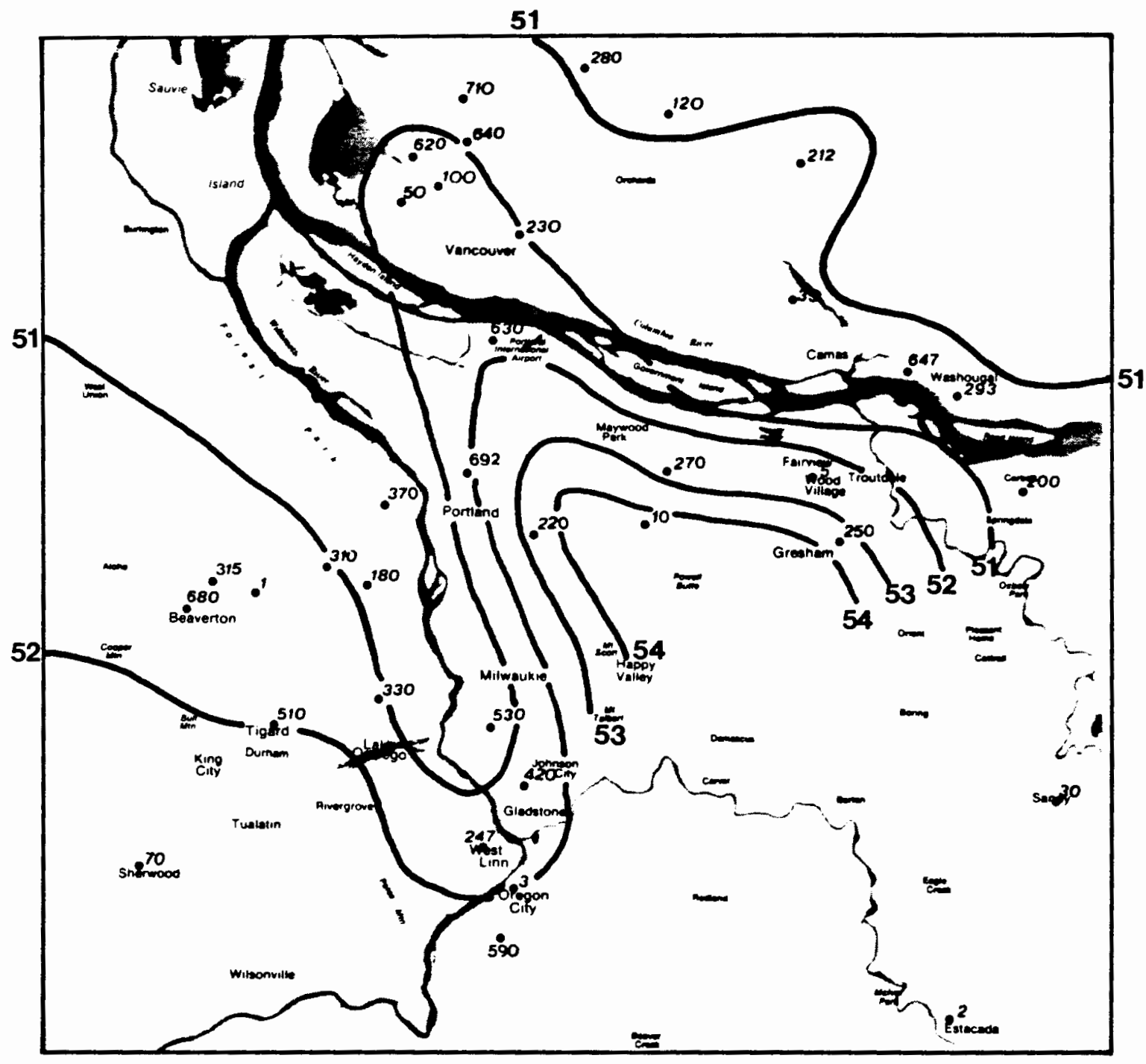

Figure 6-1. Seasonal mean temperature of Portland for spring, 1985. 


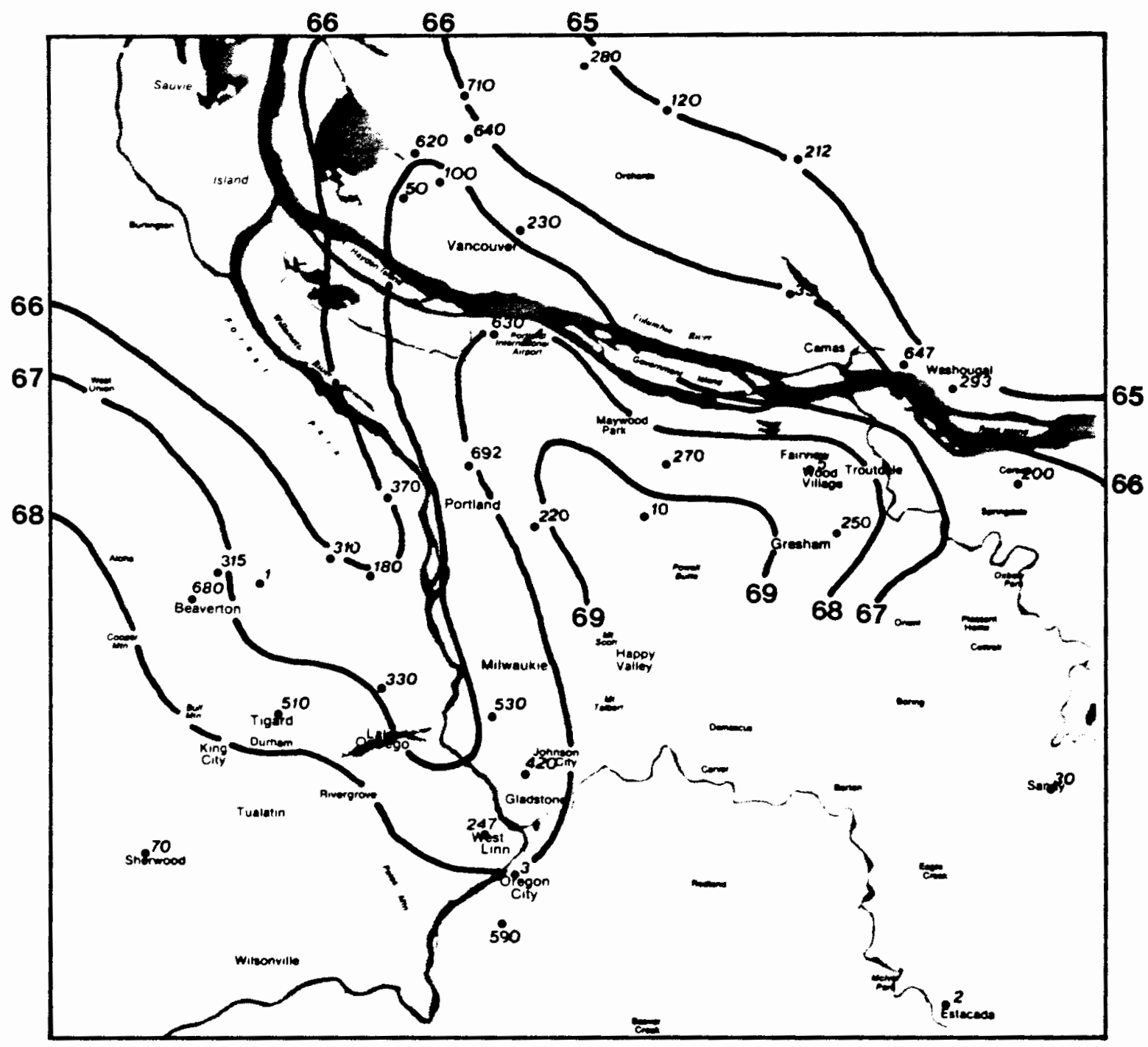

Figure 6-2. Seasonal mean temperature of Portland for summer, 1985. 


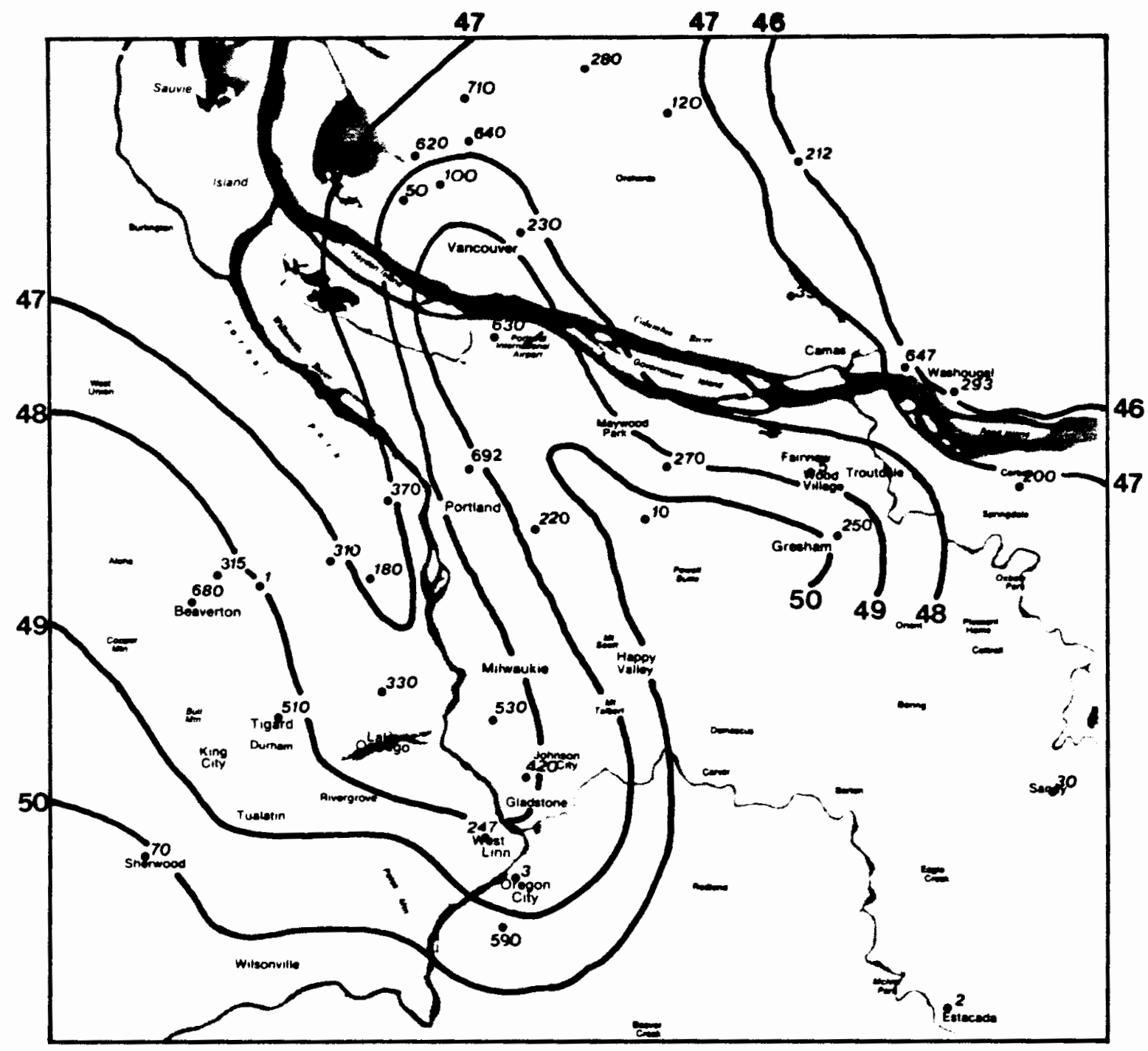

Figure 6-3. Seasonal mean temperature of Portland for fall, 1985. 


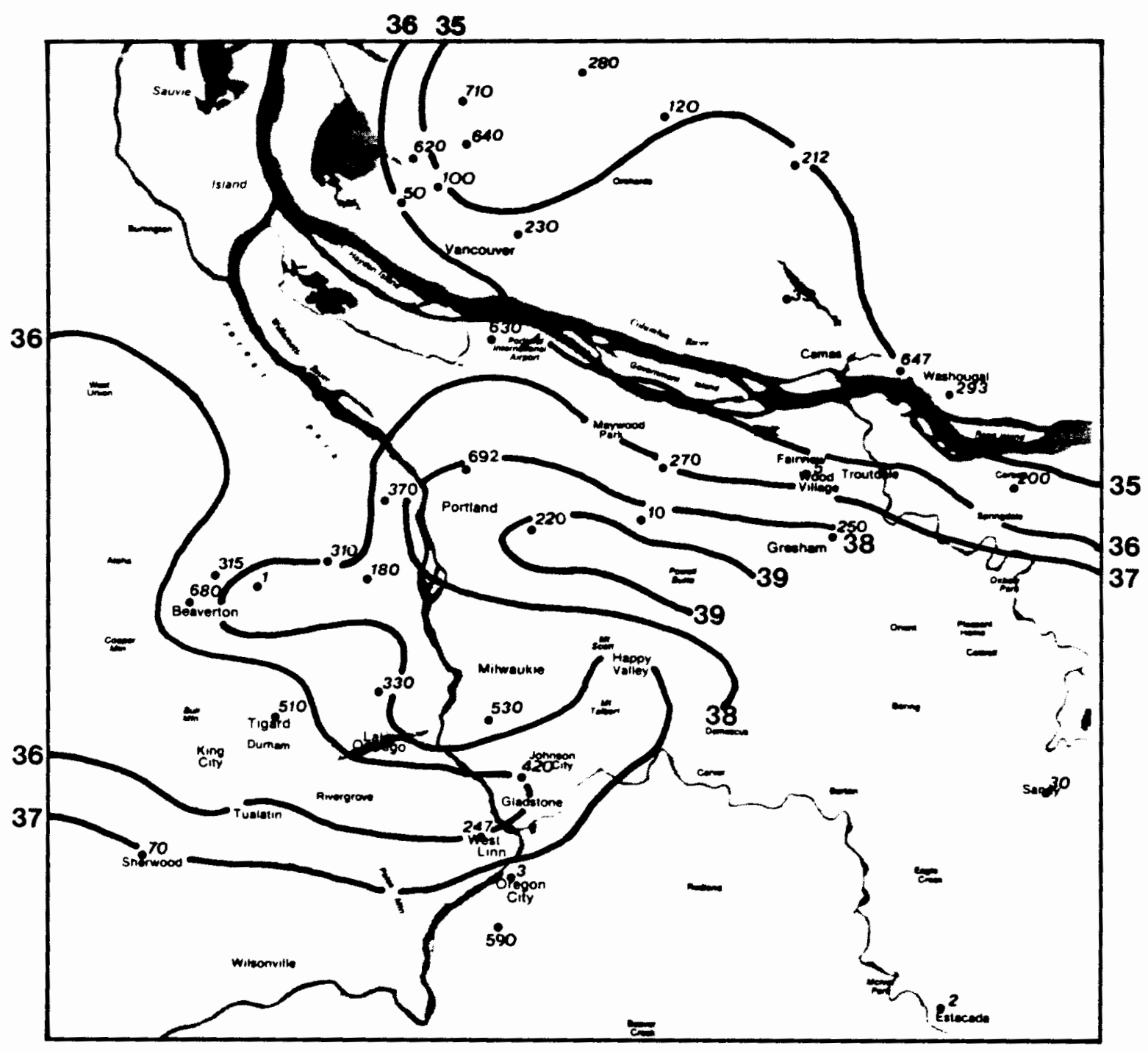

Figure 6-4. Seasonal mean temperature of Portland for winter, 1985. 


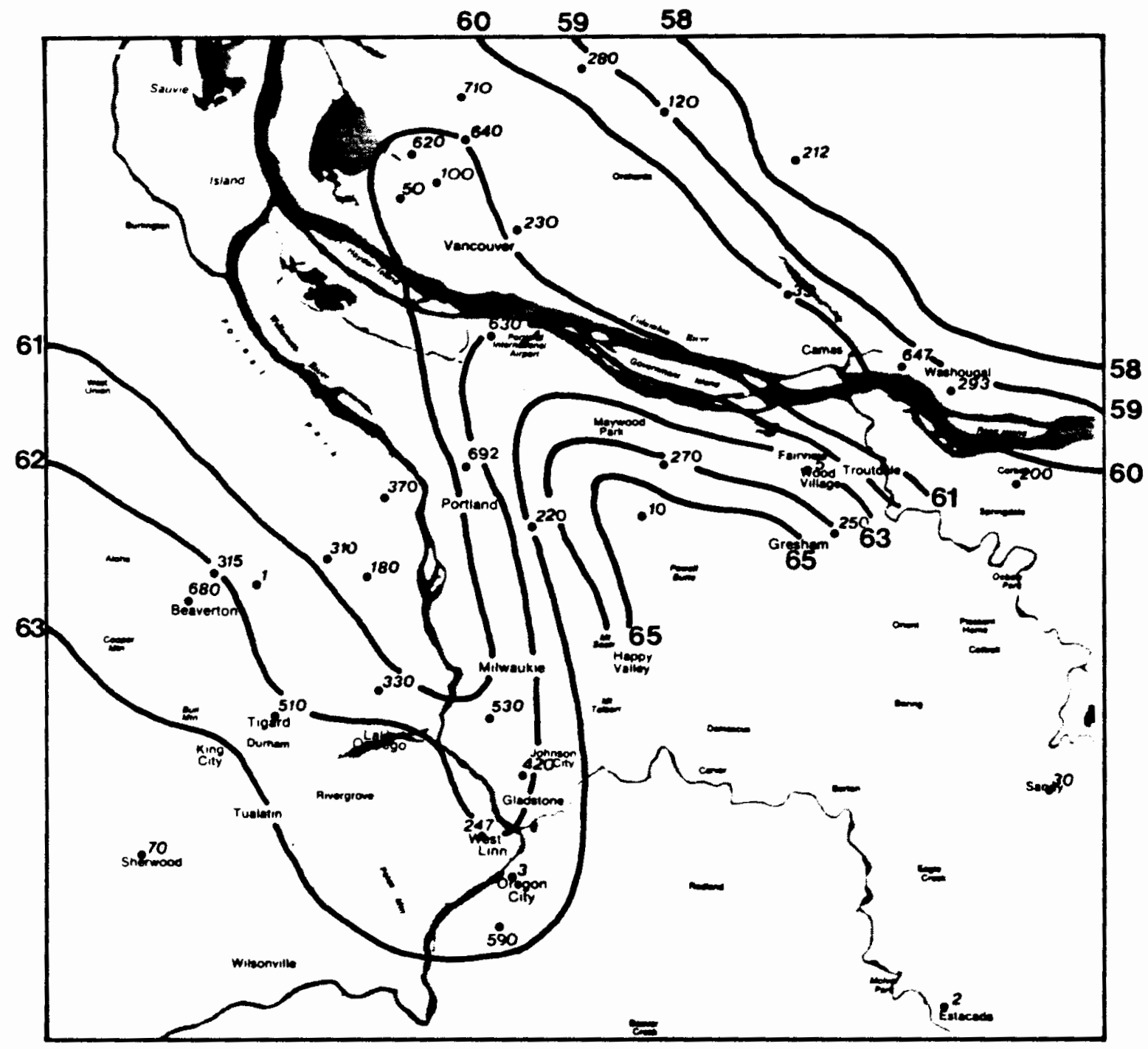

Figure $7-1$. Seasonal mean maximum temperature of Portland for spring, 1985. 


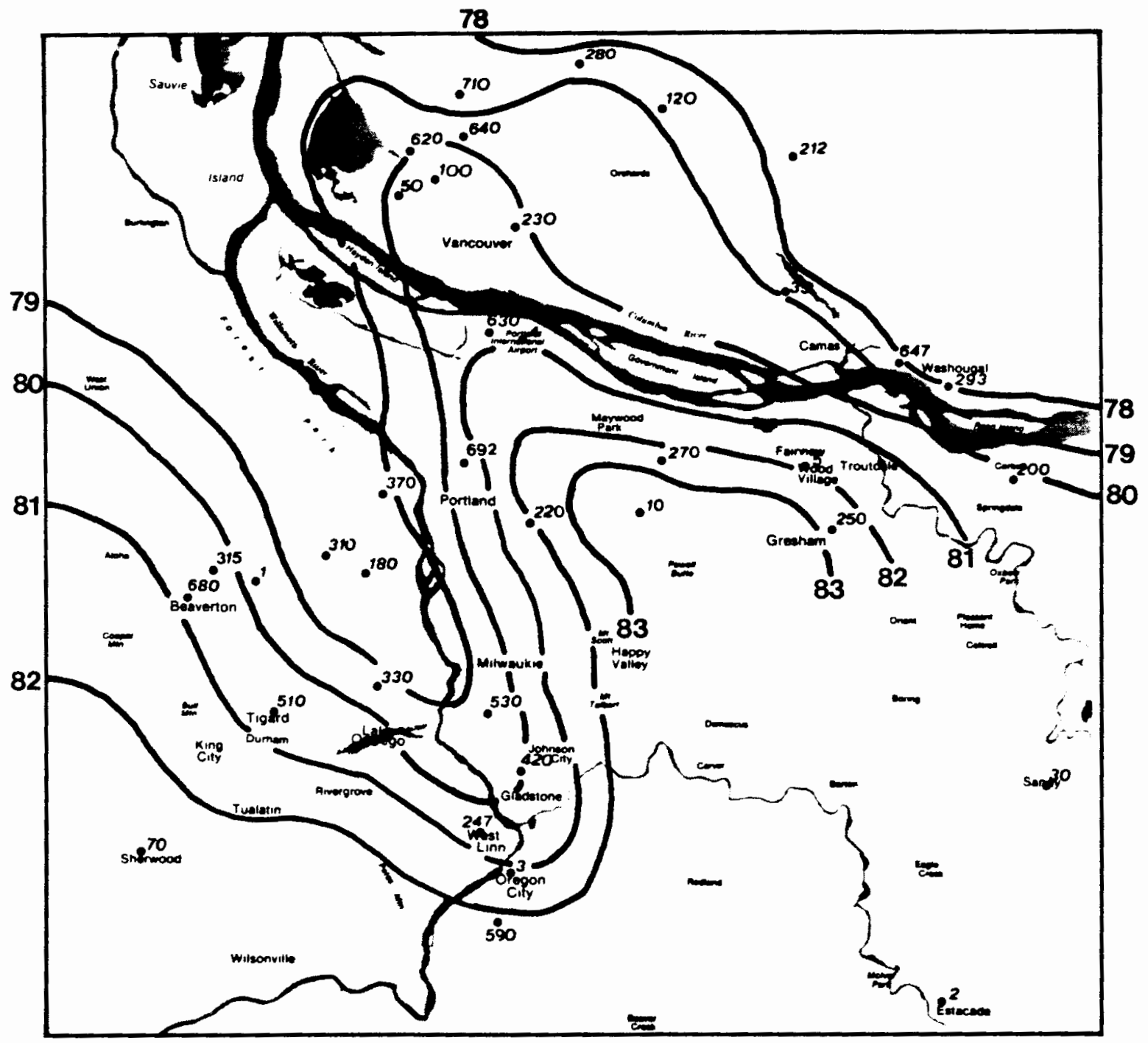

Figure 7-2. Seasonal mean maximum temperature of Portland for summer, 1985 . 


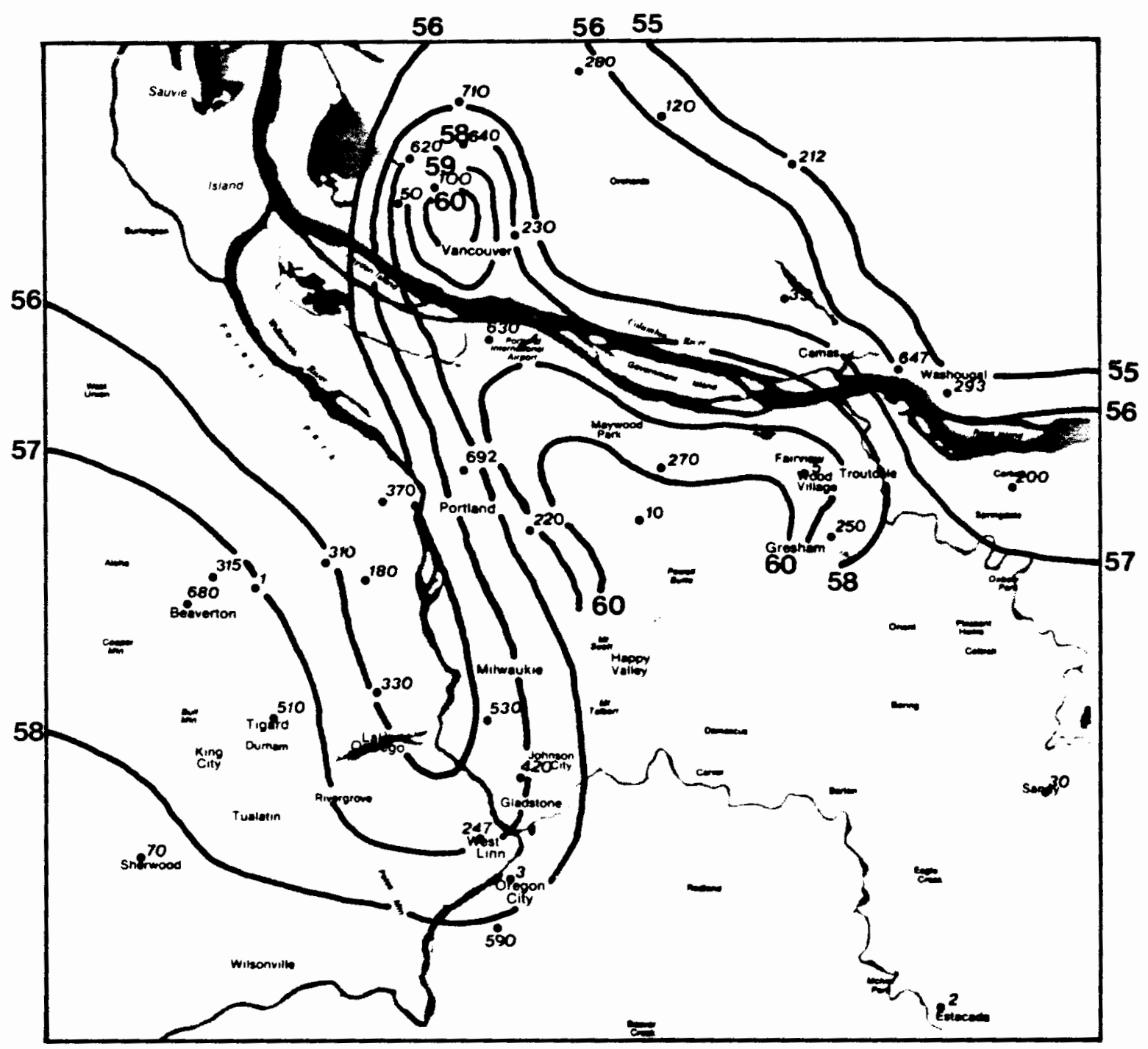

Figure 7-3. Seasonal mean maximum temperature of Portland for fall, 1985. 


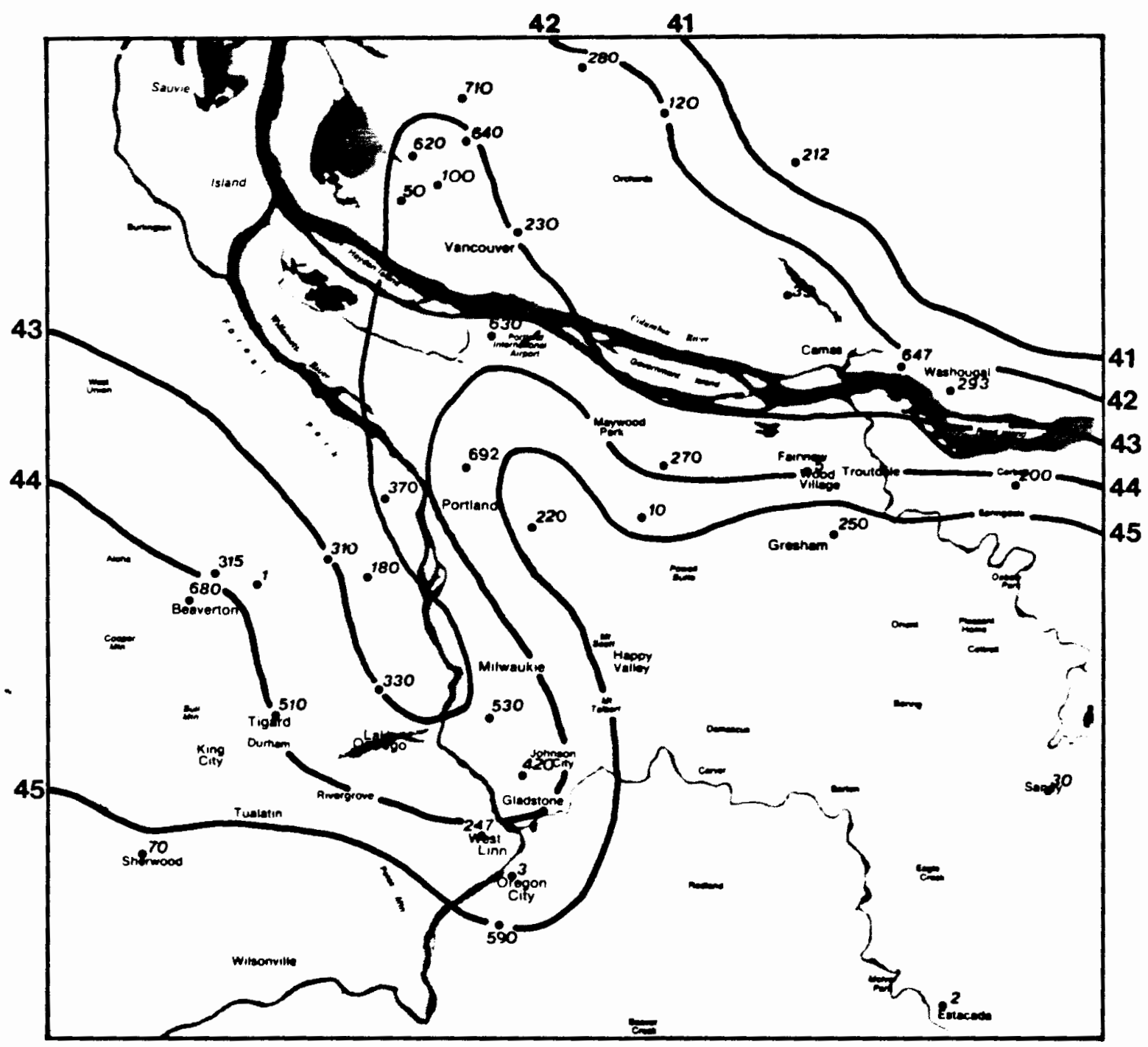

Figure 7-4. Seasonal mean maximum temperature of Portland for winter, 1985. 
North of the Columbia River from Vancouver, Washington, to the foothills of the Cascades, spatial temperature variation is less apparent, usually within $2^{\circ}$ to $3^{\circ} \mathrm{F}$. The temperature gradient does not change until the foothills of the Cascade Mountains.

As to the mean minimum temperature, the annual march of the spatial patterns behaves differently than for mean and maximum temperatures, particularly in the summer season. This will be further discussed in the following section.

\section{Seasonal Variation}

To analyze the seasonal temperature variation, the area from Beaverton in the west to Sandy in the east, and from the foothills of the Cascades in the north to Oregon City in the south, is selected for this purpose. As the heat island effect and the spatial temperature differential are best shown by temperature extremes and the locations in which these temperatures occurred, the magnitudes and sites of seasonal maximum and minimum temperatures are used for comparison.

Table IV presents the results of this analysis. Generally, temperature differential (dt) over the area is most distinctive in spring maxima and winter minima, and more pronounced during the day than at night, except in winter time. The spatial temperature differential could be more clearly identified if the temperature at the time two or three hours after sunset were recorded, when the maximum heat island usually occurs. As to the locations in which either highest or lowest temperature occurred, they are quite consistent as the mean temperature shows, except in summer minima (see also Table IV). 
TABLE IV

SEASONAL TEMPERATURE VARIATION IN THE PORTLAND AREA, 1985

\begin{tabular}{|c|c|c|c|c|c|c|c|c|c|c|}
\hline & \multicolumn{5}{|c|}{ AVERAGE DAILY MAXIMUM } & \multicolumn{5}{|c|}{ AVERAGE DAILY MINIMUM } \\
\hline & ${ }^{\circ} \mathrm{F}$ & SITE & ${ }^{0} \mathrm{~F}$ & SITE & $d t$ & ${ }^{\circ} \mathrm{F}$ & SITE & ${ }^{\circ} \mathrm{F}$ & SITE & $d t^{*}$ \\
\hline SPRING & 65 & $\begin{array}{l}\text { East } \\
\text { Portland }\end{array}$ & 58 & $\begin{array}{l}\text { Foothills of } \\
\text { the Cascades }\end{array}$ & 7 & 44 & $\begin{array}{l}\text { East } \\
\text { Port land }\end{array}$ & 40 & $\begin{array}{l}\text { Foothills of } \\
\text { the Cascades }\end{array}$ & 4 \\
\hline SUMMER & 83 & $\begin{array}{l}\text { East } \\
\text { Portiand }\end{array}$ & 78 & $\begin{array}{l}\text { Foothills of } \\
\text { the Cascades }\end{array}$ & 5 & 56 & $\begin{array}{l}\text { Downt own } \\
\text { Port land }\end{array}$ & 52 & $\begin{array}{l}\text { Foothills of } \\
\text { the Cascades }\end{array}$ & 4 \\
\hline FALL & 63 & $\begin{array}{l}\text { East } \\
\text { Port land }\end{array}$ & 55 & $\begin{array}{l}\text { Foothills of } \\
\text { the cascades }\end{array}$ & 8 & 42 & $\begin{array}{l}\text { East } \\
\text { Portland }\end{array}$ & 37 & $\begin{array}{l}\text { Foothills of } \\
\text { the Cascades }\end{array}$ & 5 \\
\hline WINTER & 45 & $\begin{array}{l}\text { East } \\
\text { Portland }\end{array}$ & 41 & $\begin{array}{l}\text { Foothills of } \\
\text { the Cascades }\end{array}$ & 4 & 3.3 & $\begin{array}{l}\text { East } \\
\text { Port rand }\end{array}$ & 26 & $\begin{array}{l}\text { Foothills of } \\
\text { the Cascades }\end{array}$ & 7 \\
\hline
\end{tabular}

* dt is the maximum spatial temperature difference either during daytime or at night.

Summer. The temperature distribution in summer changes significantly when comparing maxima with minima (Figs. 7-2, 8-2). The location of high temperature moved from east Portland during the day to near downtown Portland at night. This diurnal change is probably due to the alteration of the local airflow between day and night in summer. The dominant regional wind in this season during the day is northwestly and brings marine air to the area. The cooling effect of air is more distinctive in downtown Portland than it is further east; thus the high temperature appears east of the city area. At night, when the regional wind tends to decrease, the cooling process through longwave radiation becomes the dominant control on temperature. In the city area, surfaces made from cement and paved roads store more heat during the day and, in turn, release heat into the air at night through heat conduction when the air cools. Cooling rates outside the city are higher. In this way, the highest temperature is found at the city core area. 


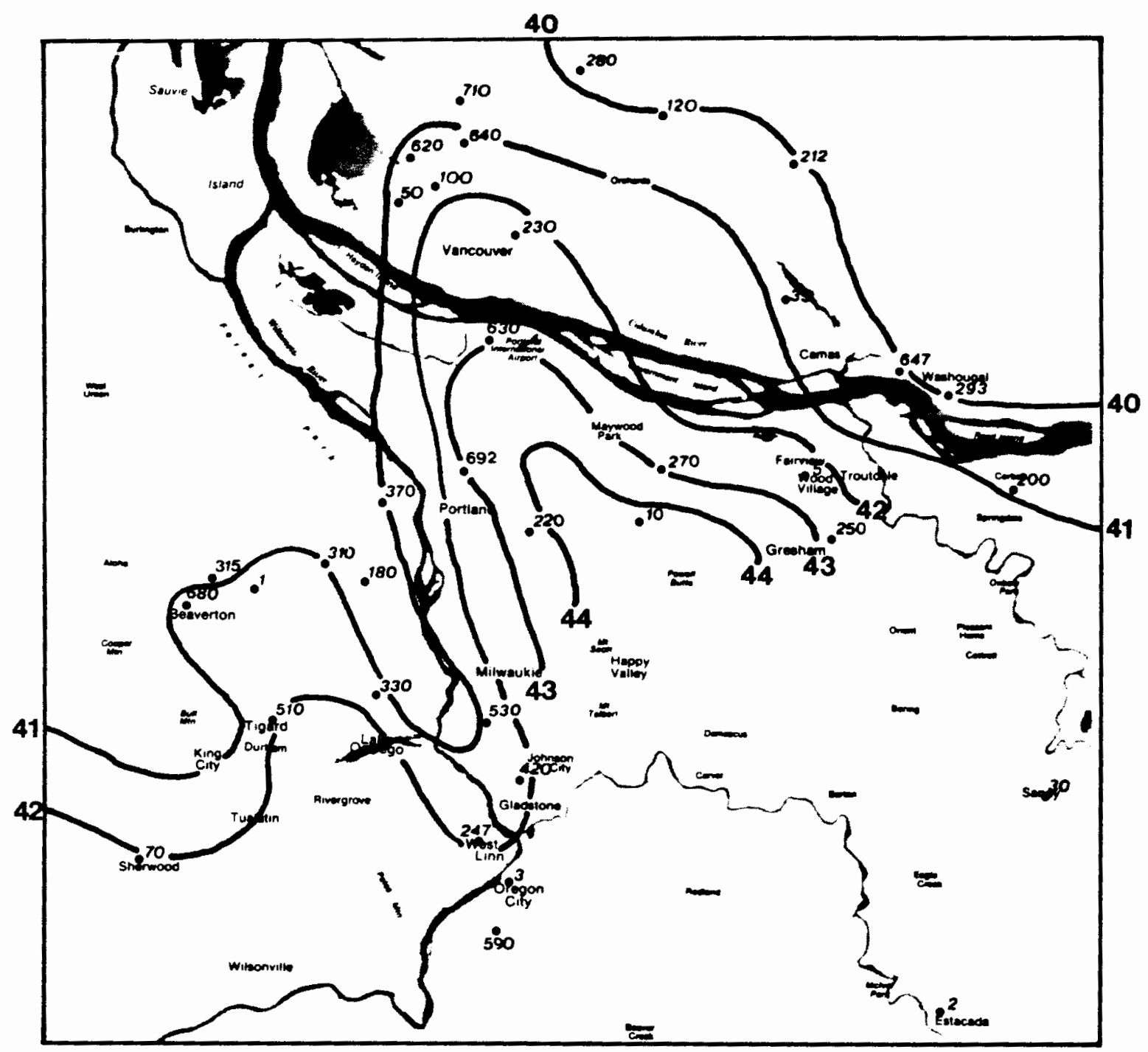

Figure 8-1. Seasonal mean minimum temperature of Portland for spring, 1985. 


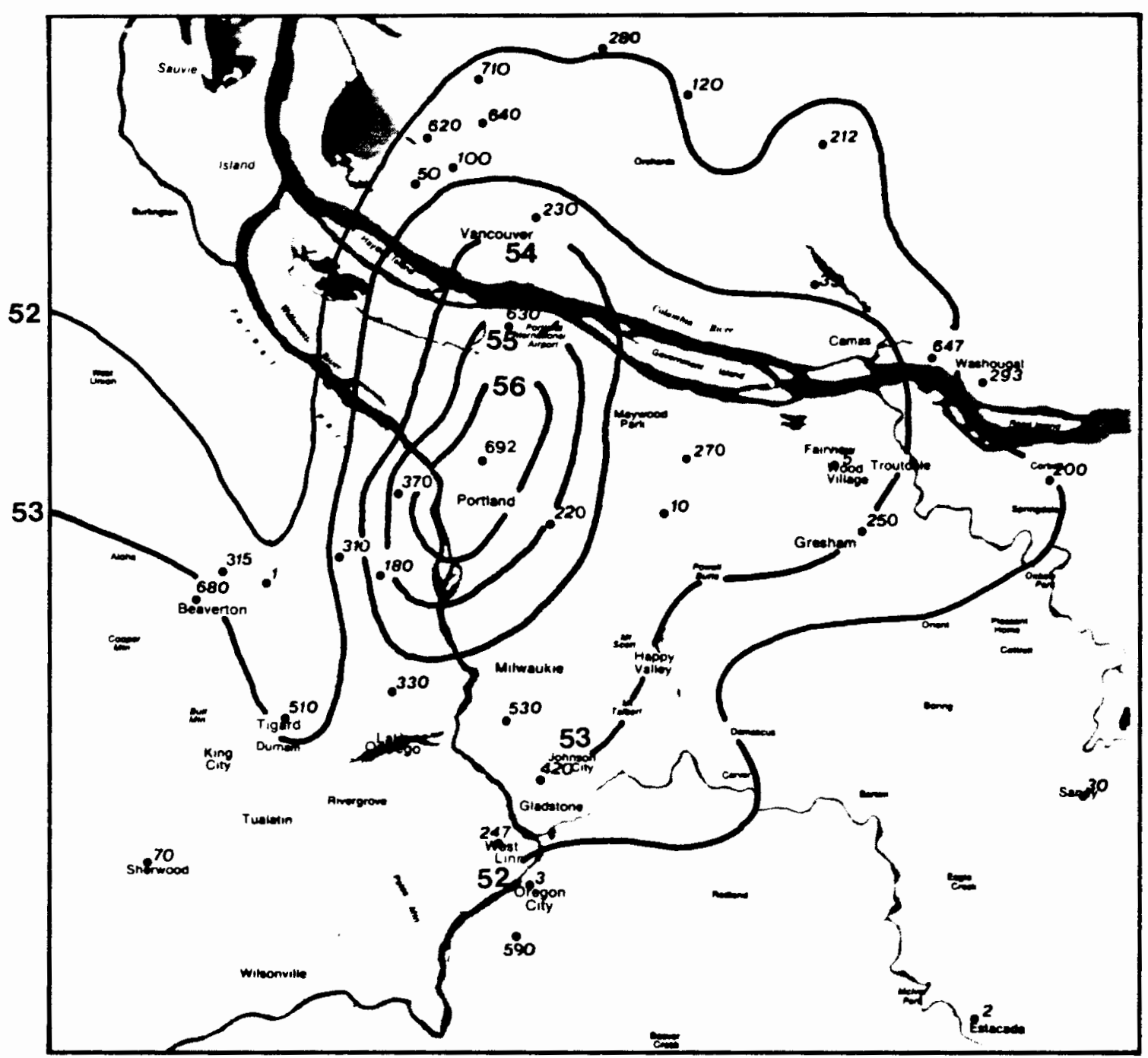

Figure 8-2. Seasonal mean minimum temperature of Portland for summer, 1985. 


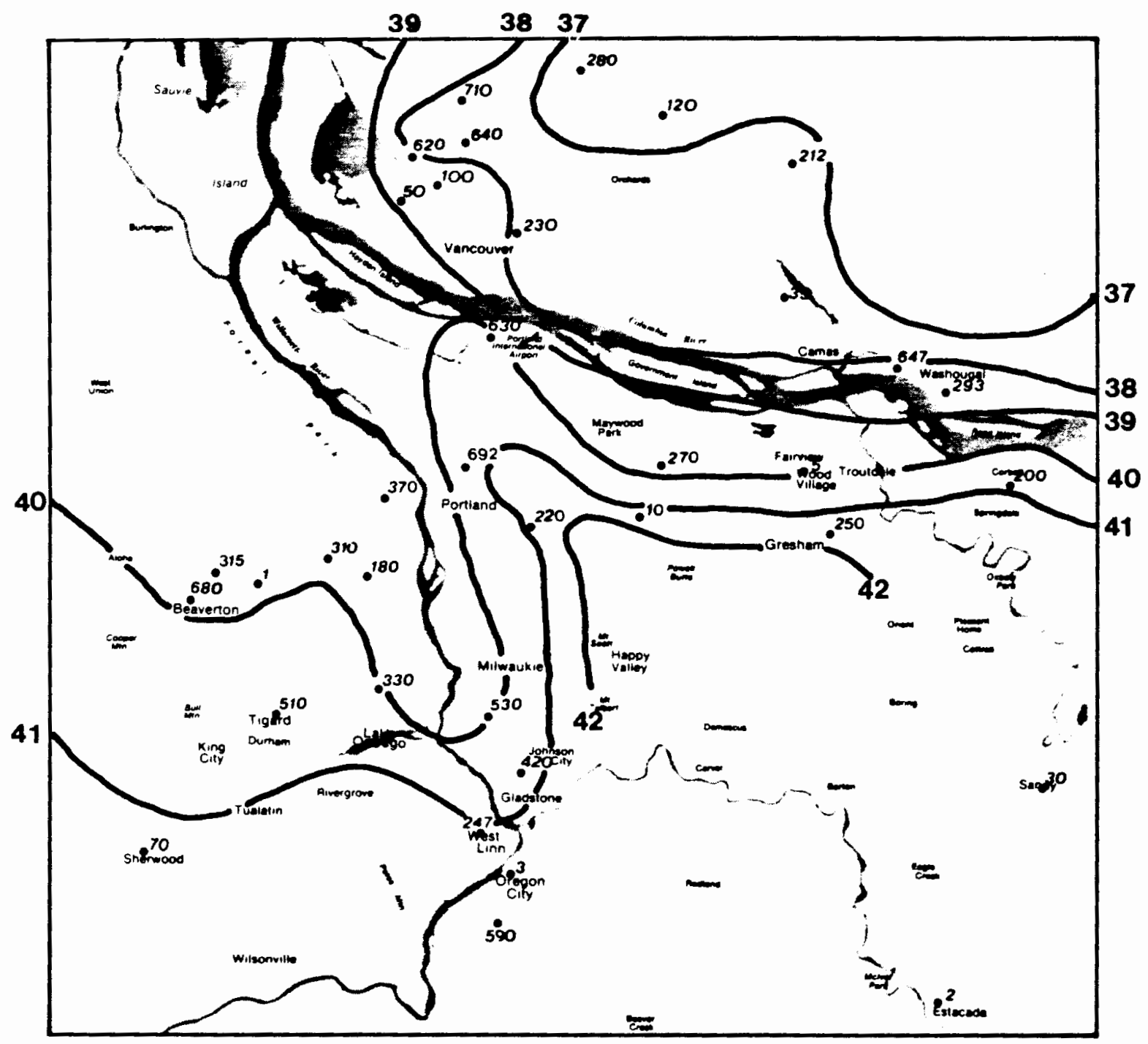

Figure 8-3. Seasonal mean minimum temperature of Portland for fall, 1985. 


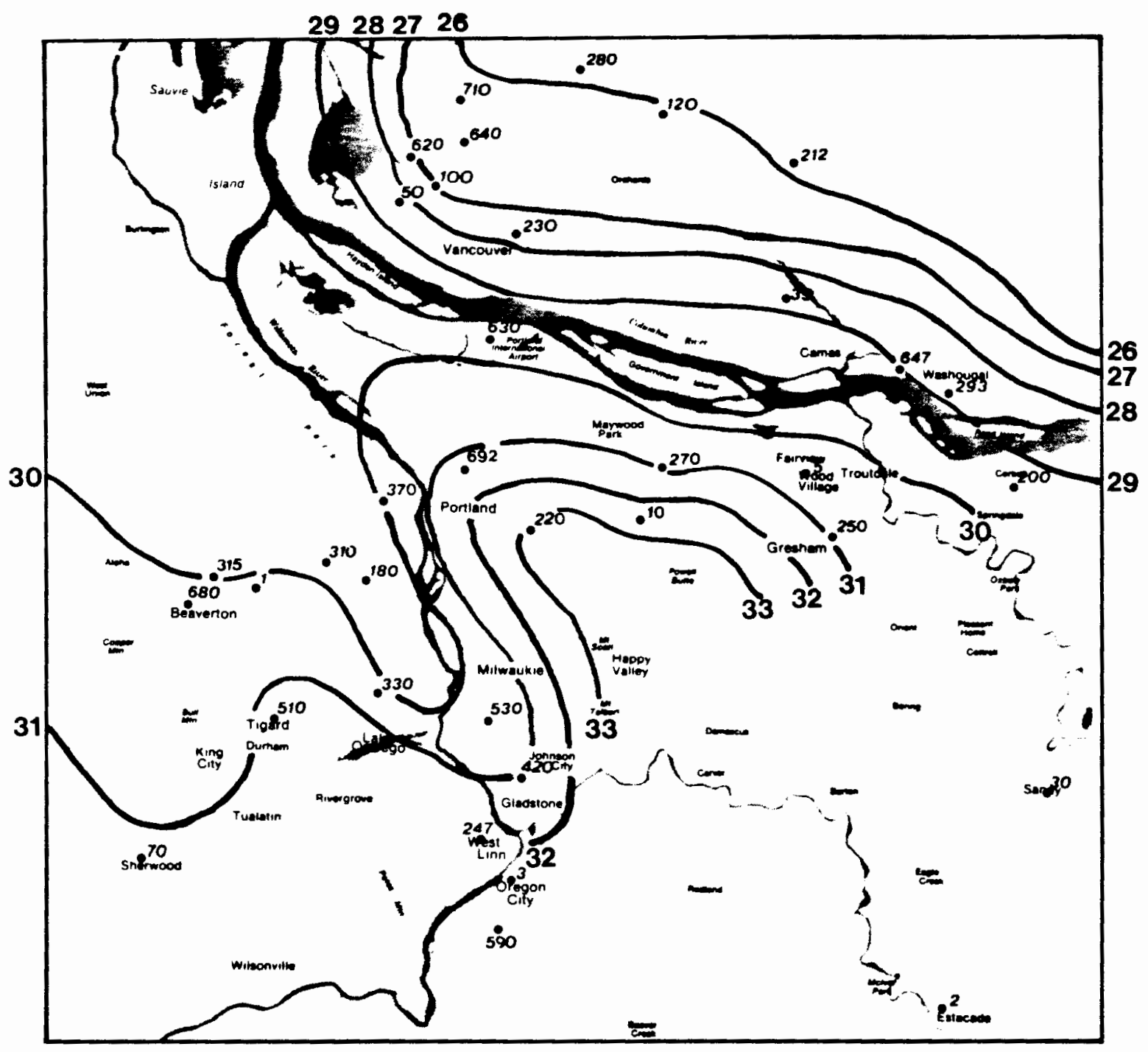

Figure 8-4. Seasonal mean minimum temperature of Portland for winter, 1985. 
The difference in the cooling process in summer between urban and non-urban areas can be identified by diurnal temperature ranges. The range of daily temperature at two stations in July were compared, one at the city core and another in the Tualatin Valley, both in the low topographic areas. The magnitude of this range at the city site is $26^{\circ}$ $\mathrm{F}\left(56^{\circ}\right.$ to $\left.82^{\circ} \mathrm{F}\right)$; at the Tualatin Valley it is $28^{\circ} \mathrm{F}\left(53^{\circ}\right.$ to $\left.81^{\circ} \mathrm{F}\right)$. The larger value of the diurnal range in non-urban area is due to more intensive cooling there caused by the vegetative surface cover and evapotranspiration.

Another possibility is that the energy released by industrial activities in the area north of the city core can generate more heat released into the city area. The effect of this additional energy on temperature increase is more appreciable at night.

Fall. Comparing maximum and minimum temperature patterns in the fall, it is clear that the cooling effect at night is quite distinctive in Vancouver, Washington (Figs. 7-3, 8-3). During the day, a closed high temperature cell is shown here, and it is one of the warmest places. At night this warm cell is weakened significantly. Similarly, the temperature pattern in the Tualat in valley also reverses somewhat from a weak warm area in daytime to a cooler one at night, suggesting that the local environment and topography are the major controls on cooling at night during this time of the year.

Winter. Temperature distribution in winter time is characterized by a large spatial differential at night. The magnitude is $7^{\circ} \mathrm{F}\left(34^{\circ}\right.$ to $27^{\circ} \mathrm{F}$ ) between the foot of the Cascades and the city of Portland, as opposed to $4^{\circ} \mathrm{F}\left(41^{\circ}\right.$ to $\left.45^{\circ} \mathrm{F}\right)$ during the day. This type of variation 
is also shown in the area between northern Vancouver and east Portland in which the temperature difference at night is $5^{\circ} \mathrm{F}$, yet only $2^{\circ} \mathrm{F}$ during the day (Fig. 7-4, 8-4). The occurrence of these large temperature ranges at night is closely related to the cooling difference at night urban versus non-urban area.

TEMPERATURE VARIATION UNDER DIFFERENT WEATHER CONDITIONS

The spatial patterns of urban temperature will vary with changing weather conditions (Unwin, 1980; Ackerman, 1985). Experience suggests that stratified data of weather conditions in every season should be introduced. Ideally, data regarding weather conditions from each study site should be attained; however, only a few stations collect these data in the Portland area. Considering that the mesoclimate should not change significantly within the area of such size, it was decided to use the Portland airport station as a control site to represent the local weather type.

Two considerations were made prior to the data analysis. First, the time duration of temperature data were chosen on a daily basis, including maxima and minima. The reason is that daily data would directly reflect the response of temperature to each weather type. Secondly, the weather types chosen were in accordance with the local climatic conditions, consisting of four major types--clear and calm (or light winds), heavy cloud cover, rainy, and windy conditions.

For a clear day, cloud cover is less than 2/10, and the average wind speed is less than $4 \mathrm{mph}$. The threshold for overcast condition is that cloud cover is greater than $7 / 10$, and the velocity of the wind less 
than $8 \mathrm{mph}$ so that no significant strong airflow exists. Samples of rainy weather were selected according to the presence of rainfall at the time when maxima and minima occurred.

Perhaps the most complicated weather condition found in the study area is during windy days. Generally, winds at the coastal area are quite constant, shifting from northwest in summer to south and southwest in winter. However, farther inland the prevailing surface winds during the year are different from the winds at the coast. The dominant direction of the surface wind in winter at Portland is east-northeast and is northwest in summer. In addition, the wind speed is changeable from time to time, causing diversified patterns of airflow and air turbulence. Considering different direction of the winds, data were categorized into two groups--east winds (including NE, SE) and west winds (including $\mathrm{NW}, \mathrm{SW}$ ).

\section{Clear Sky with Calm or Light Wind}

It has been discussed that clear skies with light winds are the most favorable weather condition for the development of local controls on climate and of significant spatial temperature differentials. Table $\checkmark$ gives the comparison between maxima and minima under this weather condition. A striking feature is the large values of spatial temperature differential in January, July, and October. As to the locations of extreme temperatures, there are a couple of cases, including April minima and January minnima, in which the spatial patterns are quite different from the normal condition. 


\section{TABLE V}

TEMPERATURE VARIATION UNDER CLEAR SKIES IN THE PORTLAND AREA, 1985

\begin{tabular}{|c|c|c|c|c|c|c|c|c|c|c|}
\hline & \multicolumn{5}{|c|}{ DAILY MAXIMUM } & \multicolumn{5}{|c|}{ DAILY MINIMUM } \\
\hline & ${ }^{0} \mathrm{~F}$ & SITE & ${ }^{\circ} \mathrm{F}$ & SITE & $d t$ & ${ }^{0} \mathrm{~F}$ & SITE & ${ }^{\circ} \mathrm{F}$ & SITE & $d t$ \\
\hline$A P R$ & 67 & $\begin{array}{l}\text { East } \\
\text { Port } 1 \text { and }\end{array}$ & 63 & $\begin{array}{l}\text { West side of } \\
\text { West Hilis }\end{array}$ & 4 & 46 & $\begin{array}{l}\text { Tualatin } \\
\text { valley }\end{array}$ & 42 & $\begin{array}{l}\text { East } \\
\text { Portland }\end{array}$ & 4 \\
\hline JUL & 98 & Gresham & 93 & $\begin{array}{l}\text { West Side of } \\
\text { West Hills }\end{array}$ & 5 & 65 & $\begin{array}{l}\text { East } \\
\text { Port } 1 \text { and }\end{array}$ & 55 & $\begin{array}{l}\text { Foothills of } \\
\text { the Cascades }\end{array}$ & 10 \\
\hline OCT & 63 & Gresham & 55 & $\begin{array}{l}\text { West Side of } \\
\text { West Hills }\end{array}$ & 8 & 65 & $\begin{array}{l}\text { East } \\
\text { Portland }\end{array}$ & 58 & $\begin{array}{l}\text { Foothills of } \\
\text { the Cascades }\end{array}$ & 7 \\
\hline JAN & 41 & $\begin{array}{l}\text { Tualat in } \\
\text { valley }\end{array}$ & 35 & $\begin{array}{l}\text { East } \\
\text { Portland }\end{array}$ & 5 & 30 & $\begin{array}{l}\text { East } \\
\text { Portiand }\end{array}$ & 23 & $\begin{array}{l}\text { Foothills of } \\
\text { the rascades }\end{array}$ & 7 \\
\hline
\end{tabular}

In July, the area's temperature difference at night reached $10^{\circ} \mathrm{F}$, the largest value found in the year. During the day the value was smaller, below $5^{\circ} \mathrm{F}$. This case is in agreement with previous studies in that the minimum temperature under the clear sky in summer time tends to show a larger value of temperature differential (Lowry, 1967; Landsberg, 1970). Another feature showed by minimum temperature distribution is that the high temperature was seen in the area from the Portland airport to the east (Fig. 9-1).

Temperature distribution in April is unique under the clear sky conditions. This is marked by a significant change between the times of maximum and minimum. For maximum temperature, the warmest area extended from east Portland to Gresham (Fig. 9-2). However, when minima occurred, temperature in this region was lower than that of its surrounding areas. This kind of phenomenon has also been reported by other researchers in some places, and is usually termed the negative heat island. For example, Ackerman (1985) found that the negative heat is land generally occurred in the spring and early summer in Chicago. 
The explanation for this phenomenon in Portland is not apparent, but is probably due partially to the effects of local topography. It is speculated that locally induced air circulation caused by differences of elevation and topography can contribute to the formation of the negative heat island. Around sunset, under clear skies and light wind, the air on the West Hills and the foot of the Cascade Mountains cools off quite rapidly due to its higher elevation; then the air masses contract and tend to move downhill. Meanwhile, the lower valley area in between two major rivers is relatively warm and the air will rise up from the valley. In this way, the local hill-valley induced breeze will develop. The air moving downslope will cool off the valley when it moves in, compensating for the outflow of the air from the valley. The presence of light winds would be unfavorable for the formation of temperature inversions near the surface so that this local air circulation can last for several hours at night. By dawn, the valley is cooled off quite intensively, causing a negative heat island.

\section{Windy Conditions}

The prevailing wind over the Pacific Northwest from April to August is the northwesterly. This occurs due to the regional atmospheric circulation pattern in which the Subtropical Pacific High migrates northward and dominates the northeast Pacific. The typical pattern when the westerlies occur is the presence of a ridge over the northeast Pacific, and a low pressure system over the central United States. The Pacific Northwest is at the front of the ridge on the surface. From September to March, the prevailing winds in Portland are southeasterlies (Fig. 10-1). The surface air pressure displays two low and one high 


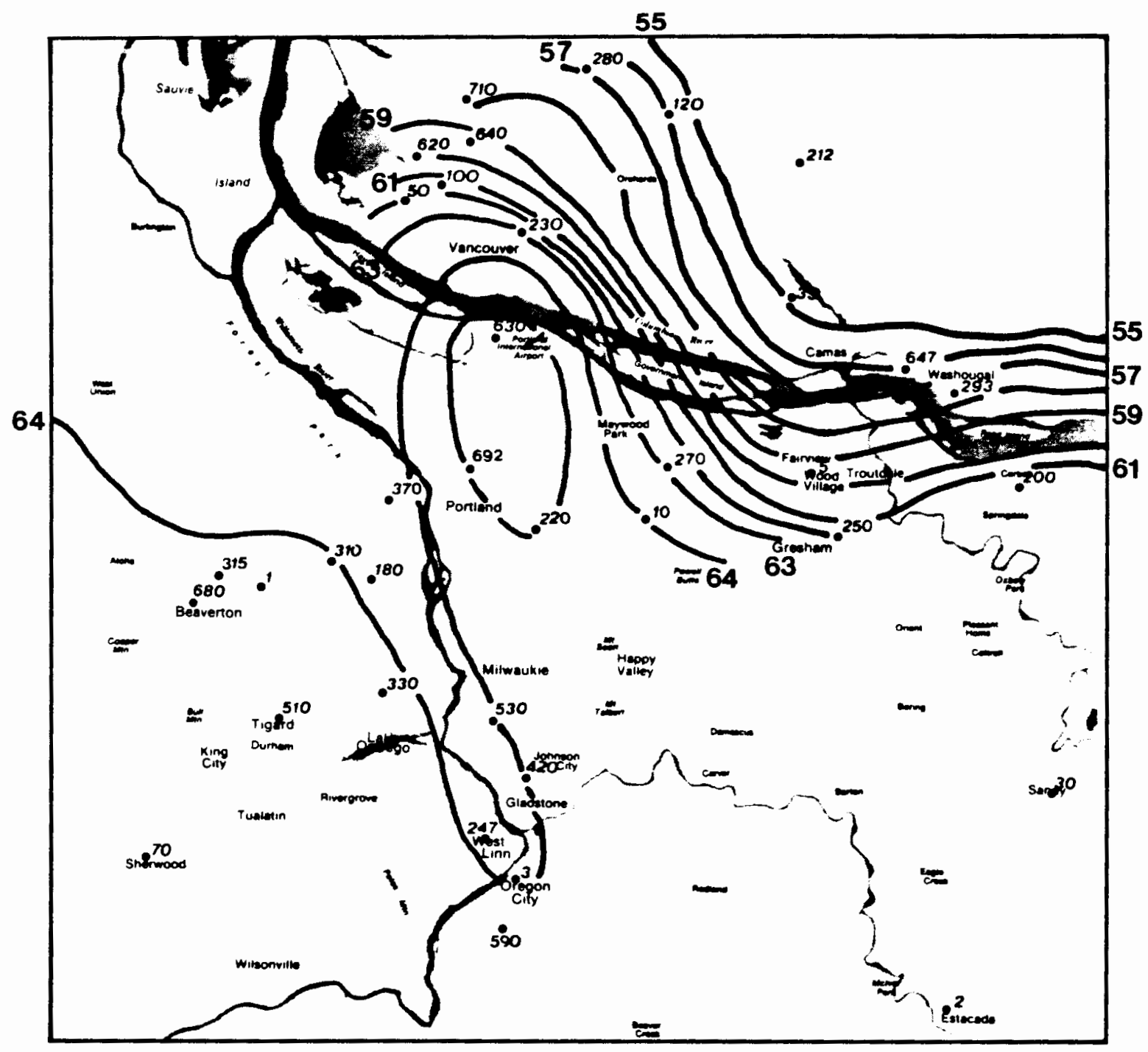

Figure 9-1. Minimum temperature distribution under clear skies in July, 1985. 


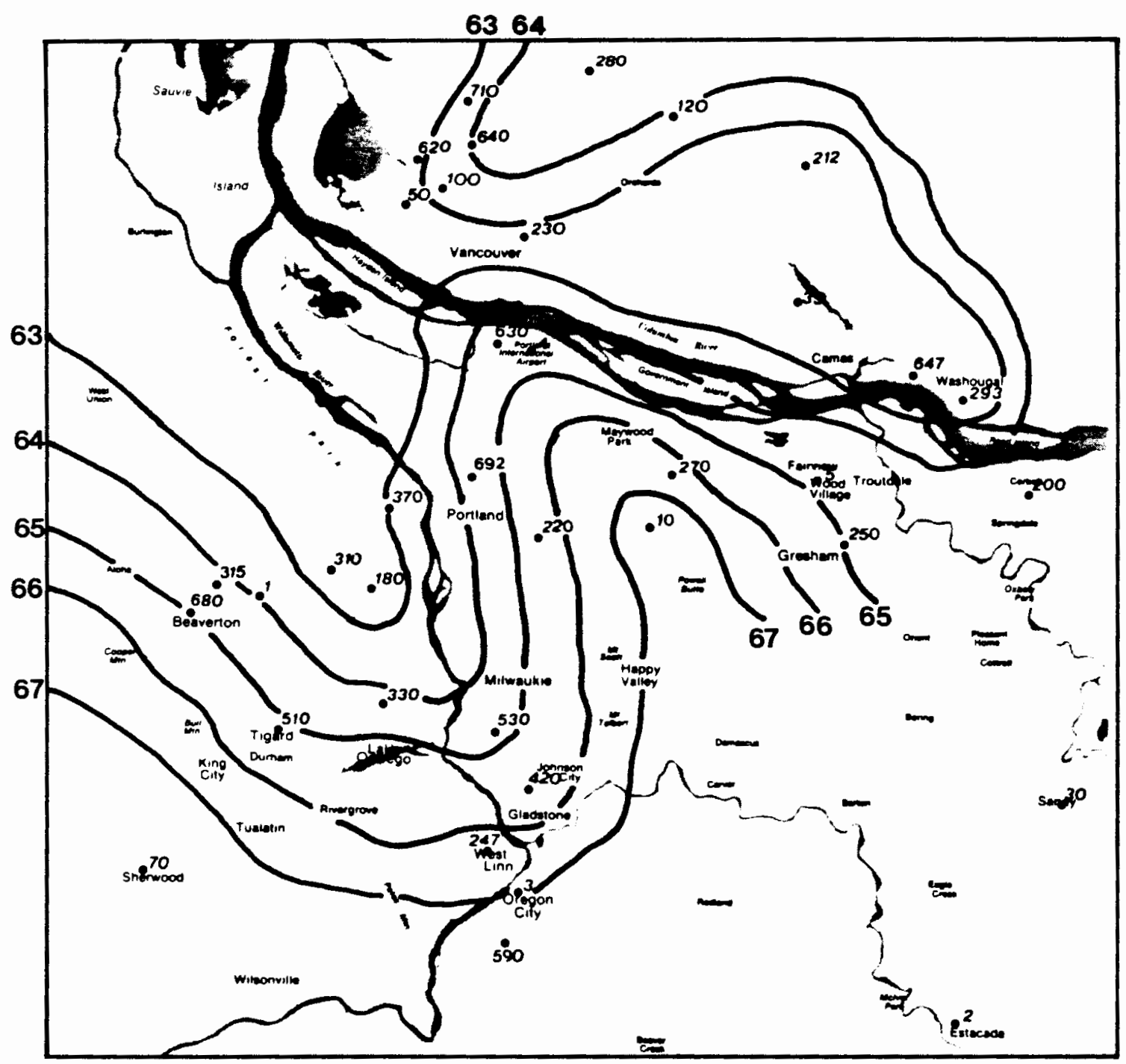

Figure 9-2. Maximum temperature distribution under clear skies in April, 1985. 


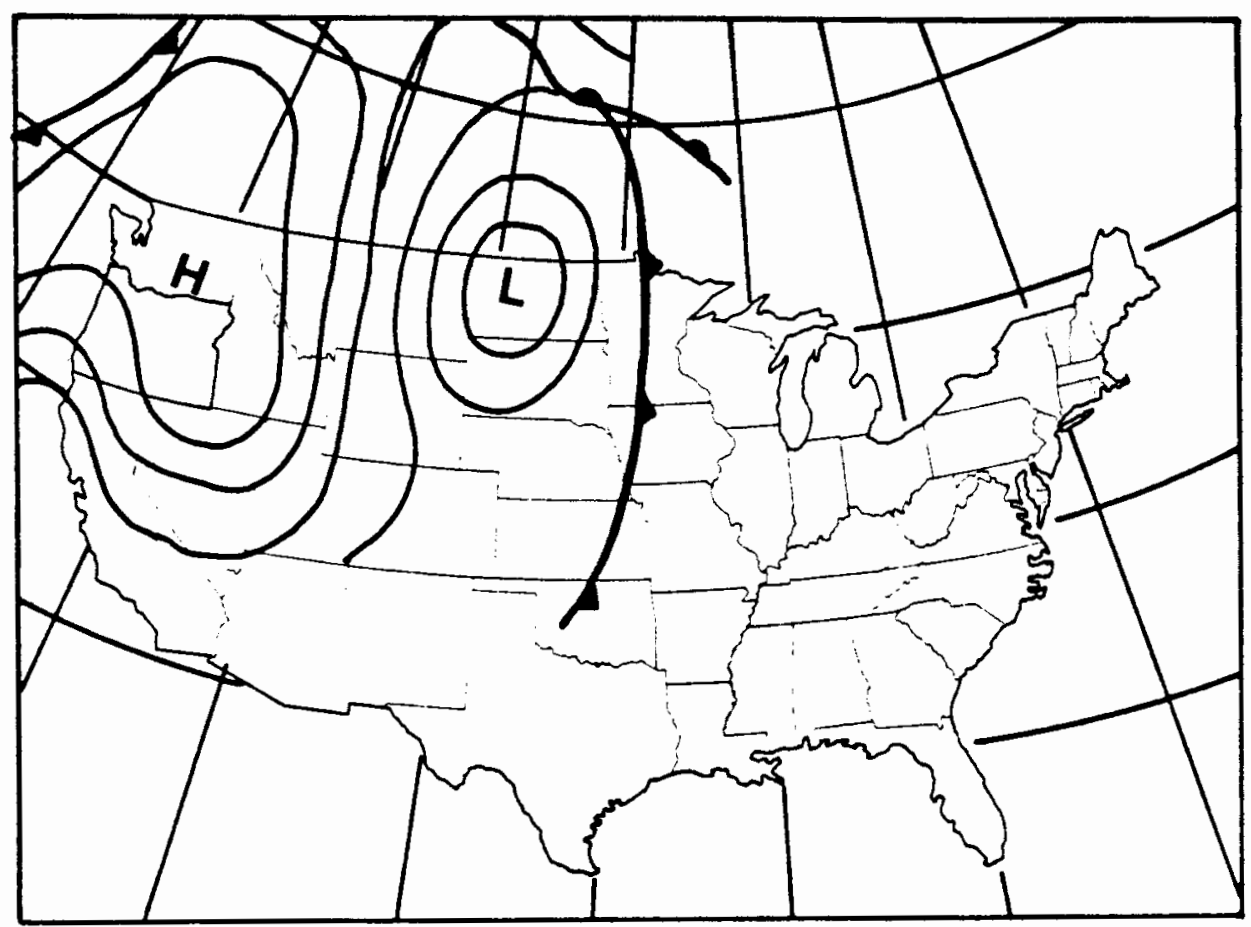

Figure 10-1. Surface synoptic pressure pattern for typical east wind

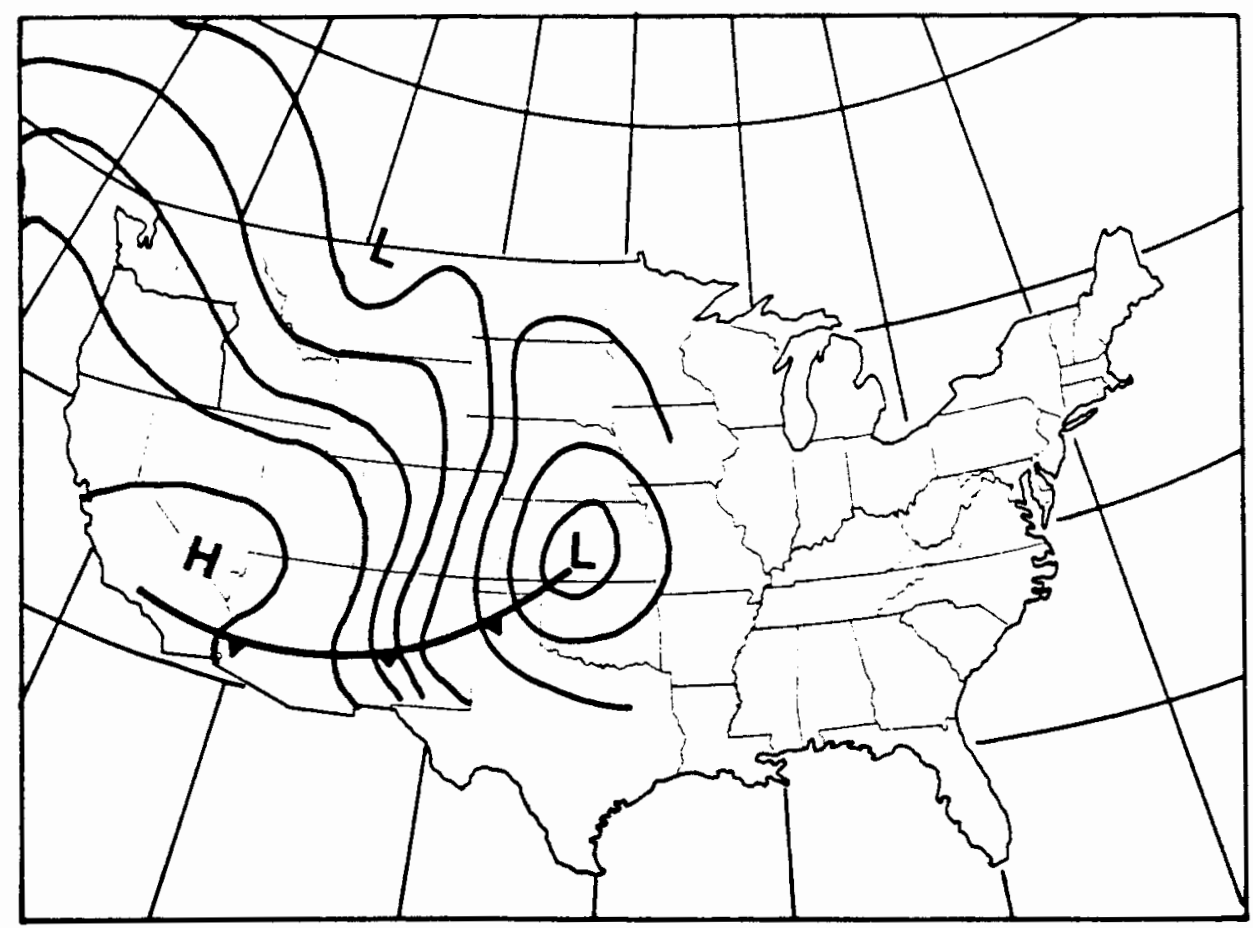

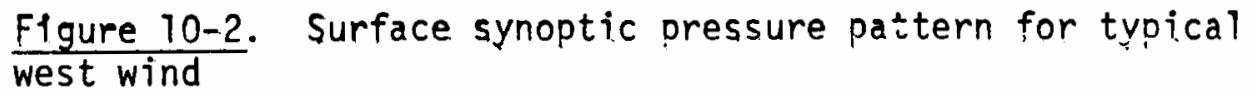


pressure cells are found in southwestern Canada and the northwestern United States (Fig. 10-2). At $500 \mathrm{mb}$ a ridge usually persists in the Pacific Northwest, and airflow on the front of the ridge intensifies the higher pressure on the ground. Therefore, east or southeast winds will develop near the surface in western Oregon.

Table VI and Table VII illustrate Portland's temperature variation under these prevailing winds. In April and July, winds tend to reduce spatial temperature variation as compared to the clear sky condition; the effect is less distinct in october and January. The daily maximum under east wind is usually seen at Vancouver, indicating the strong cooling in Portland by the east wind. When westerlies dominate in warmer months, the maximum temperature is found farther inland at Gresham, a response to marine air modification (see Table VII). In contrast, the location of minima under either east or west winds does not change significantly. Some cases are chosen to further analyze the spatial temperature variation under different wind conditions.

TABLE VI

TEMPERATURE VARIATION UNDER WEST WIND IN THE PORTLAND AREA, 1985

\begin{tabular}{|c|c|c|c|c|c|c|c|c|c|c|}
\hline & \multicolumn{5}{|c|}{ DAILY MAXIMUM } & \multicolumn{5}{|c|}{ DAILY MINIMUM } \\
\hline & ${ }^{o} \mathrm{~F}$ & SITE & ${ }^{\circ} \mathrm{F}$ & SITE & $d t$ & ${ }^{0} \mathrm{~F}$ & SITE & ${ }^{0} \mathrm{~F}$ & SITE & $d t$ \\
\hline APR & 73 & Gresham & 69 & $\begin{array}{l}\text { Foothills of } \\
\text { the Cascades }\end{array}$ & 4 & 44 & $\begin{array}{l}\text { Downt own } \\
\text { Portland }\end{array}$ & 34 & $\begin{array}{l}\text { Foothills of } \\
\text { the Cascades }\end{array}$ & 10 \\
\hline JUL & 87 & Gresham & 82 & $\begin{array}{l}\text { West Side of } \\
\text { West Hilis }\end{array}$ & 5 & 55 & $\begin{array}{l}\text { Downtown } \\
\text { Portland }\end{array}$ & 51 & $\begin{array}{l}\text { Foothills of } \\
\text { the Cascades }\end{array}$ & 4 \\
\hline OCT & -- & -- & - & -- & - & -- & -- & -- & -- & - \\
\hline JAN & - & -- & - & -- & - & -- & -. & -- & -- & - \\
\hline
\end{tabular}


TABLE VII

TEMPERATURE VATIATION UNDER EAST WIND IN THE PORTLAND AREA, 1985

\begin{tabular}{|c|c|c|c|c|c|c|c|c|c|c|}
\hline & \multicolumn{5}{|c|}{ DAILY MAXIMUM } & \multicolumn{5}{|c|}{ OAILY MINIMUM } \\
\hline & ${ }^{0} \mathrm{~F}$ & SITE & ${ }^{\circ} \mathrm{F}$ & SITE & $d t$ & ${ }^{\circ} \mathrm{F}$ & SITE & ${ }^{\circ} \mathrm{F}$ & SITE & $d t$ \\
\hline APR & 77 & $\begin{array}{l}\text { East } \\
\text { Portland }\end{array}$ & 76 & $\begin{array}{l}\text { Foothills of } \\
\text { the Cascades }\end{array}$ & 1 & $\cdots$ & -- & - & -- & - \\
\hline JUL & -- & -- & -- & -- & - & 60 & $\begin{array}{l}\text { Downtown } \\
\text { Portland }\end{array}$ & 56 & $\begin{array}{l}\text { Foothills of } \\
\text { the Cascades }\end{array}$ & 4 \\
\hline OCT & 59 & $\begin{array}{l}\text { Vancou- } \\
\text { ver }\end{array}$ & 52 & $\begin{array}{l}\text { Foothills of } \\
\text { the Cascades }\end{array}$ & 7 & 41 & $\begin{array}{l}\text { East } \\
\text { Portland }\end{array}$ & 35 & $\begin{array}{l}\text { Foothills of } \\
\text { the Cascades }\end{array}$ & 6 \\
\hline JAN & 41 & $\begin{array}{l}\text { Vancou- } \\
\text { ver }\end{array}$ & 35 & Gresham & 6 & 36 & $\begin{array}{l}\text { East } \\
\text { Portiand }\end{array}$ & 26 & $\begin{array}{l}\text { Foothills of } \\
\text { the Cascades }\end{array}$ & 6 \\
\hline
\end{tabular}

Northwest Winds. Under moderate or strong northwest winds (>7 mph) in July, the maximum temperature distribution in the Willamette Valley appeares to be strongly influenced. As seen in Figure 11-1, the farther the station is from the ocean, the warmer it is, showing the cooling effect of the marine air during the summer. In the Tualatin Valley, temperature does not seem to be dominated by the winds. Local topography probably masks the impact of the airflow. The mountain barrier on the west side of the Tualatin Valley may also weaken the cooling effect of the marine air.

To detect temperature behavior under different winds at night, two days influenced by almost reversed wind direction yet the same wind speed are compared. As shown in Figure 11-2 and 11-3, minimum temperatures of these two days show an almost reversed pattern in the area between the Willamette and Columbia Rivers. This indicates that the air coming from different directions at night is responsible for the minimum temperature distribution.

When an even stronger northwest wind dominates, the area of highest 
temperature migrates farther east, streching from Gresham to Corbett, and the temperature gradient is even smaller. The temperature difference during daytime at the city area is only 1 to $2^{\circ} \mathrm{F}$, and $3^{\circ} \mathrm{F}$ at night. Outside the city, the former is under $6^{\circ} \mathrm{F}$, the latter is $5^{\circ} \mathrm{F}$ to $6^{\circ} \mathrm{F}$. This smaller spatial variation is certainly due to the strong airflow which intensifies the process of sensible heat exchange, and modifies other influential temperature factors.

East and Southeast Winds. Spatial temperature distribution under southeast winds in 0ctober shows quite a different pattern between maxima and minima. During the day, the high temperature cell is found in Vancouver, rather than in Portland. It shifts back to Portland when the minimum temperature occurs (Figs, 12-1, 12-2). This is probably due to different temperature control factors in the day versus night. During the day, strong east winds coming from the Columbia Gorge bring in cool air, and Portland's proximity to the Gorge allows the cooling effects to be more severe than farther north and south. Consequently, the high temperature cell is found outside Portland. Since longwave radiation at night is the dominant control over surface temperature, the strong cooling in the non-urban area results in a more rapid temperature decrease.

In April, the maximum temperature is significantly affected by strong easterly winds. A clearly smoothed temperature distribution is seen (Fig. 12-3). The daytime temperature differential from the Tualatin Valley to the foothills of Cascades is only $2^{\circ} \mathrm{F}$. 


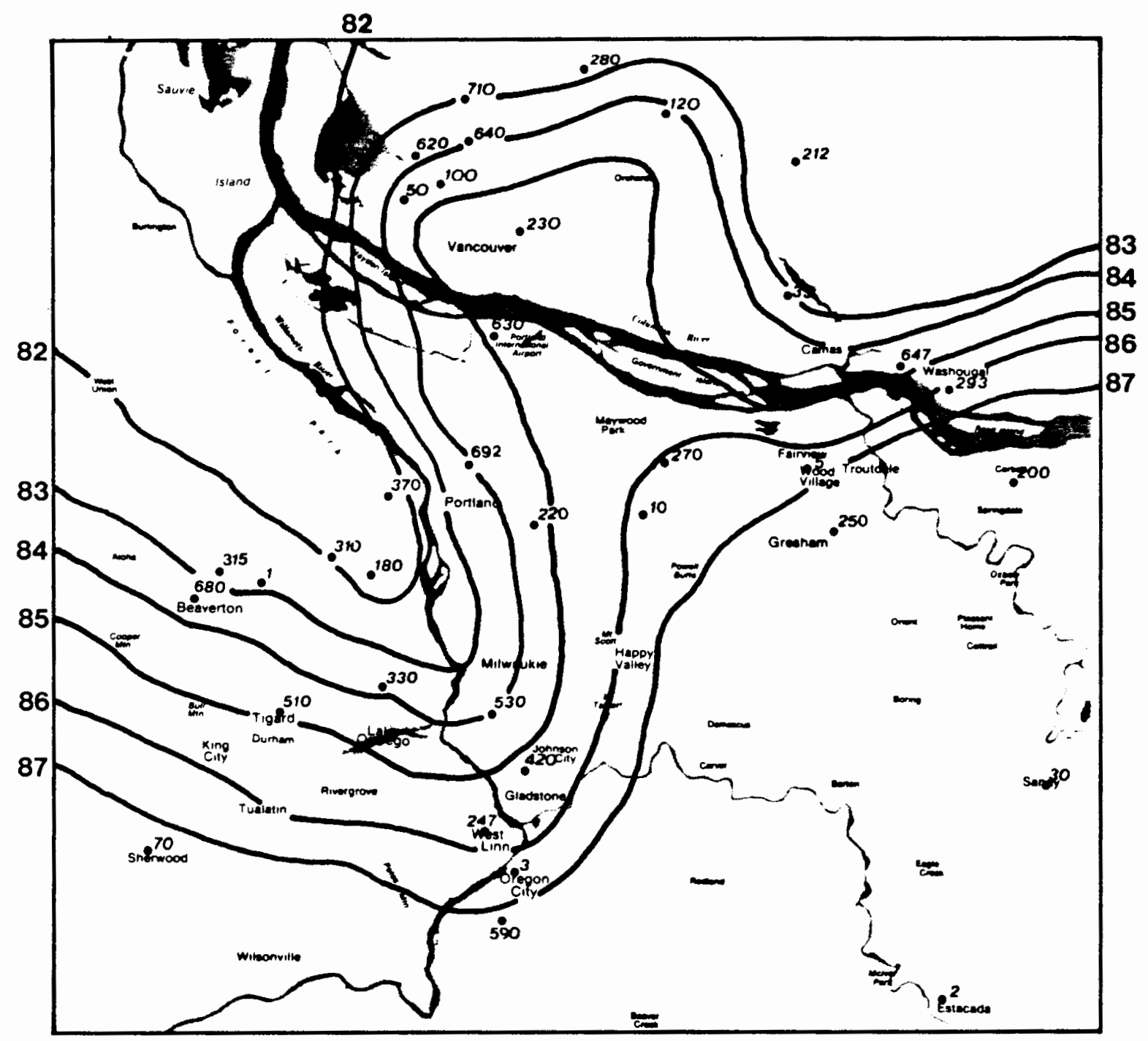

Figure 11-1. Maximum temperature distribution under west wind in July, 1985. 


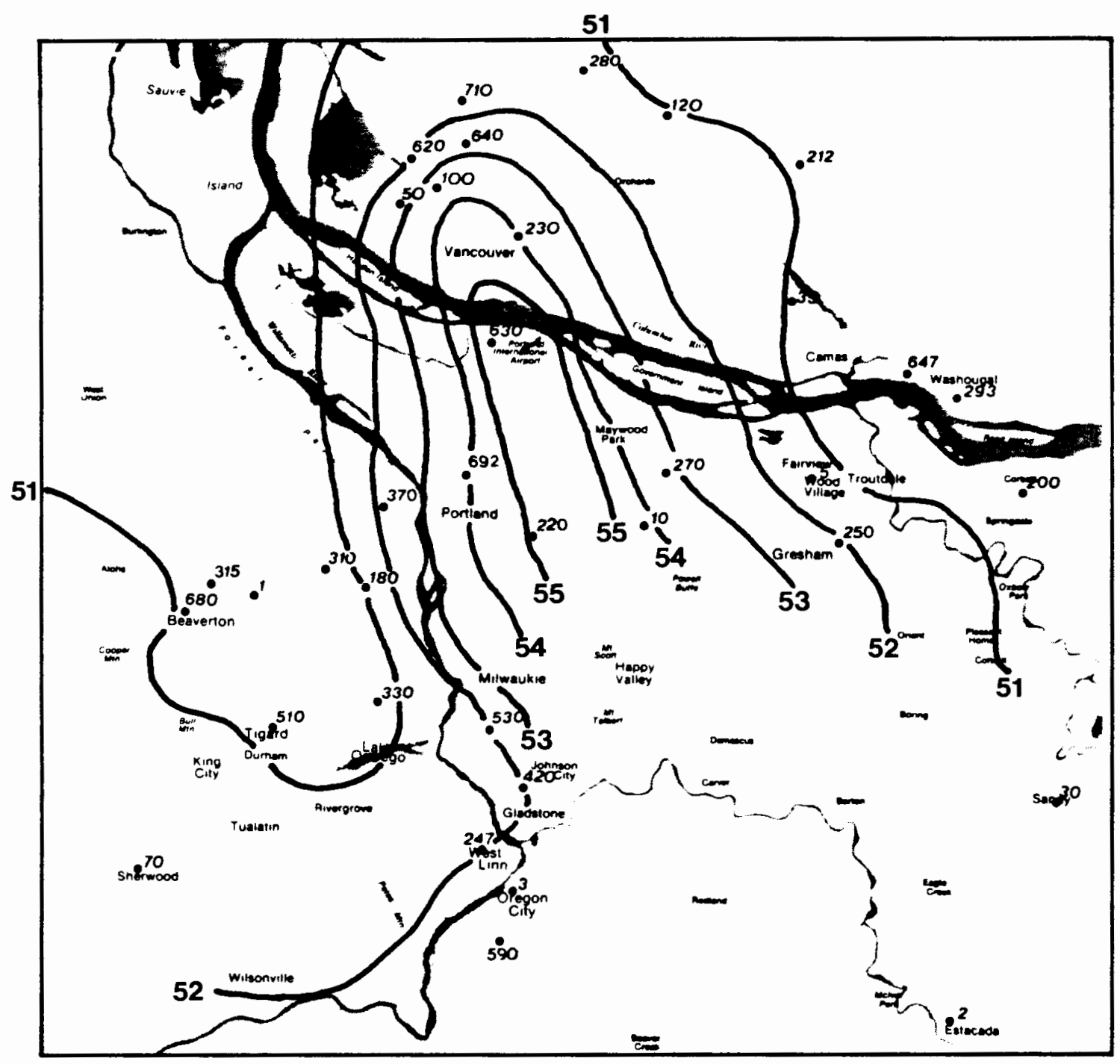

Figure 11-2. Minimum temperature distribution under west wind in July, 1985. 


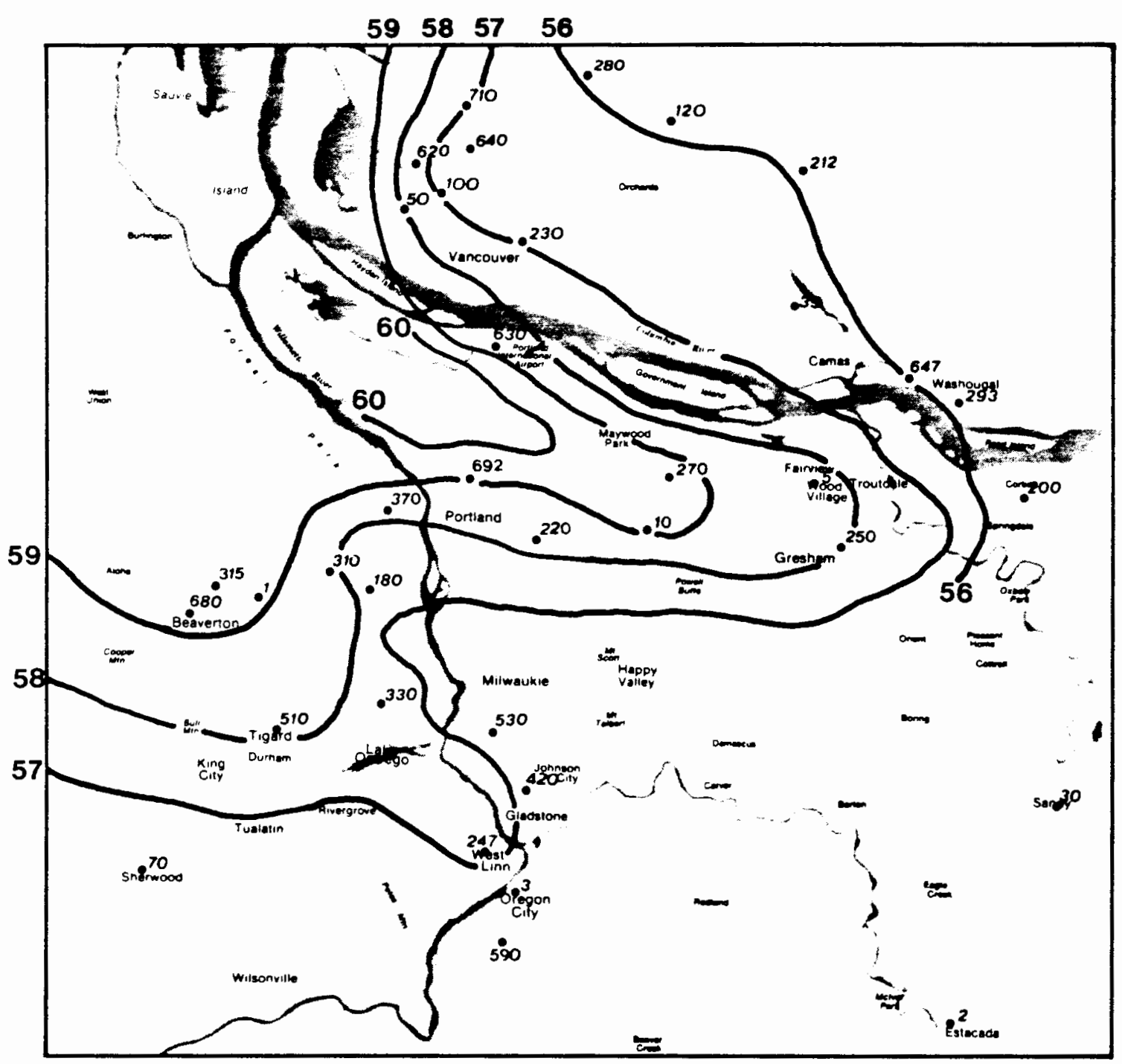

Figure 11-3. Minimum temperature distribution under east wind in July, 1985. 


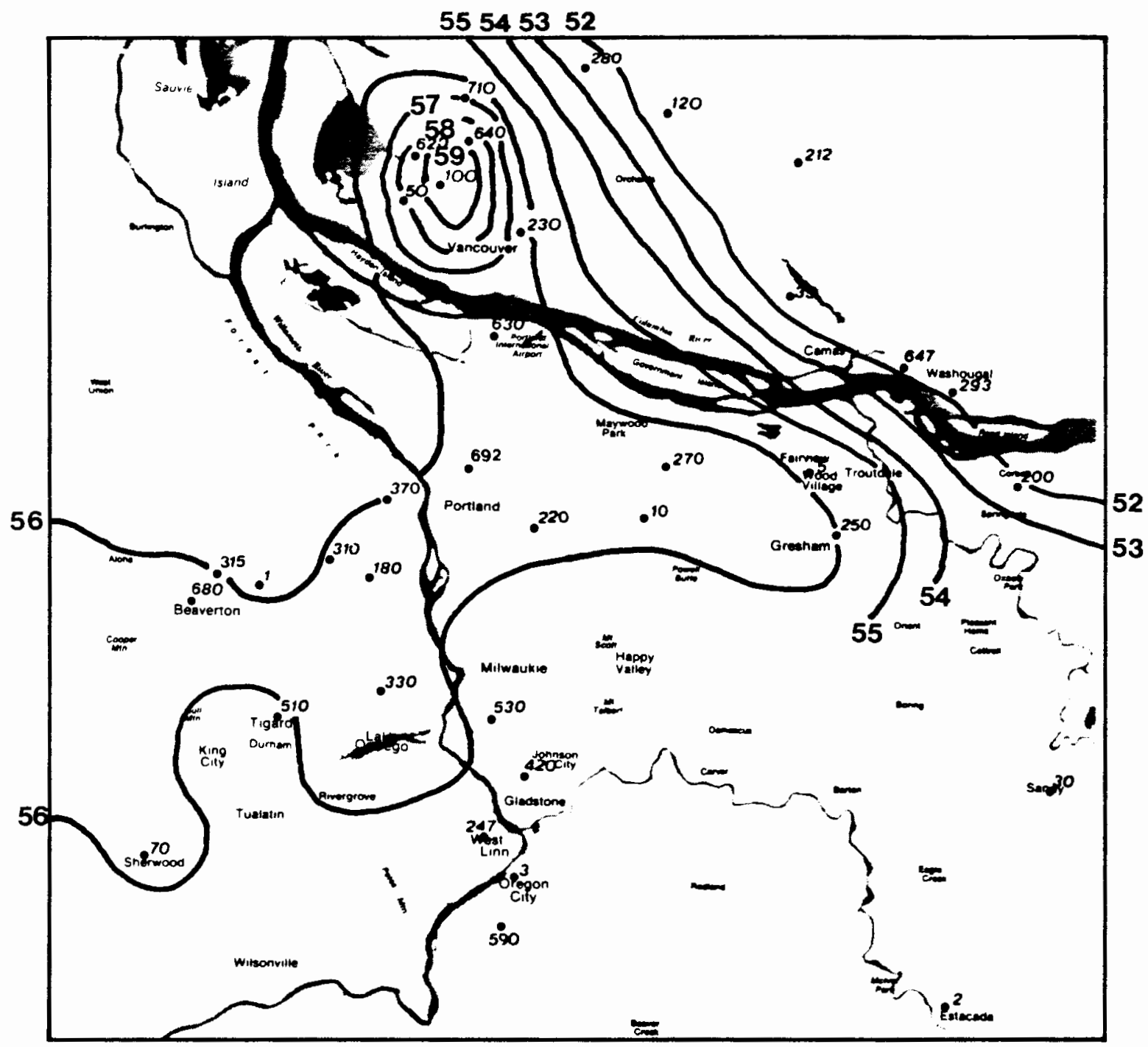

Figure 12-1. Maximum temperature distribution under east wind in October, 1985. 


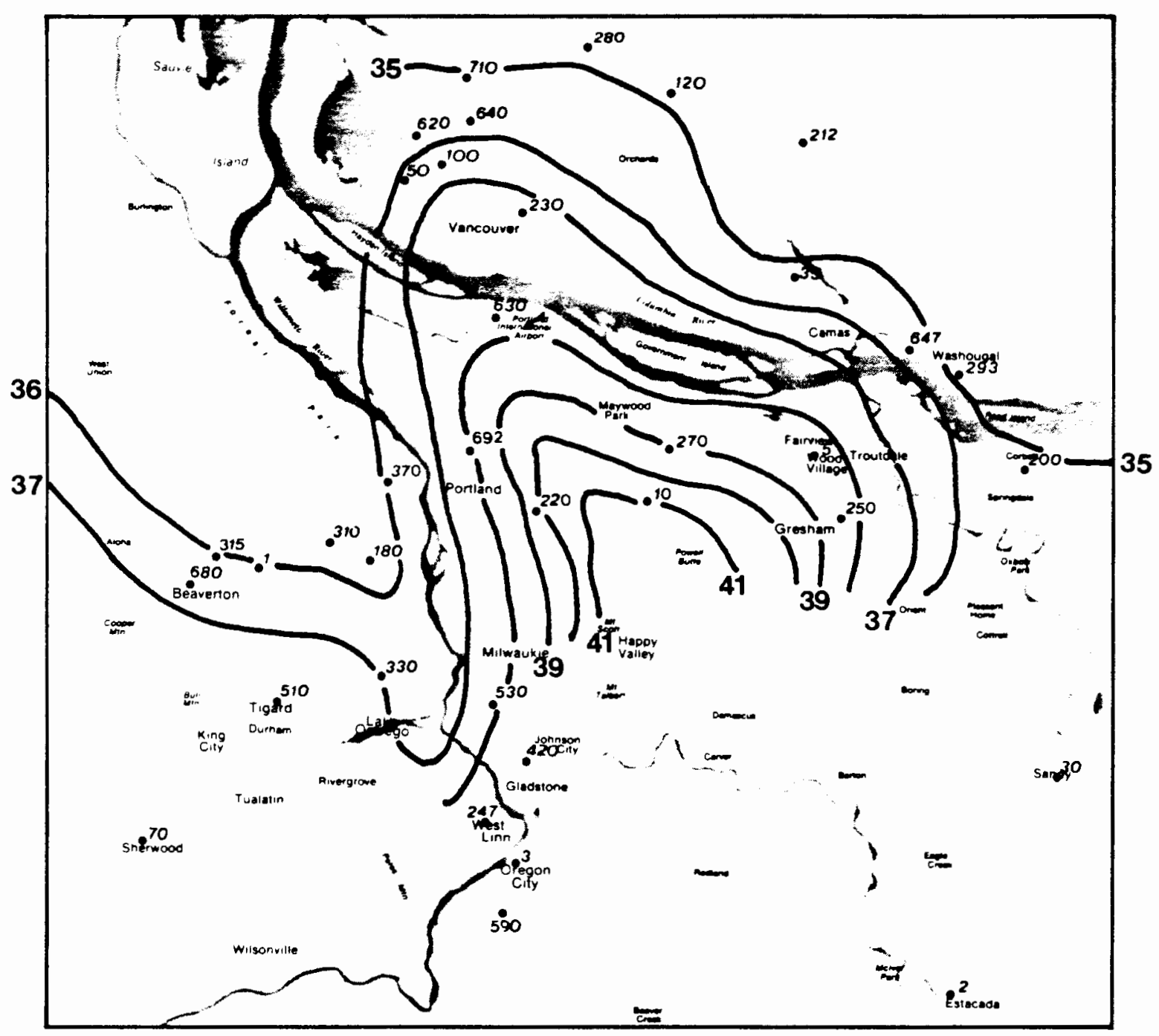

Figure 12-2. Minimum temperature distribution under east wind in October, 1985. 


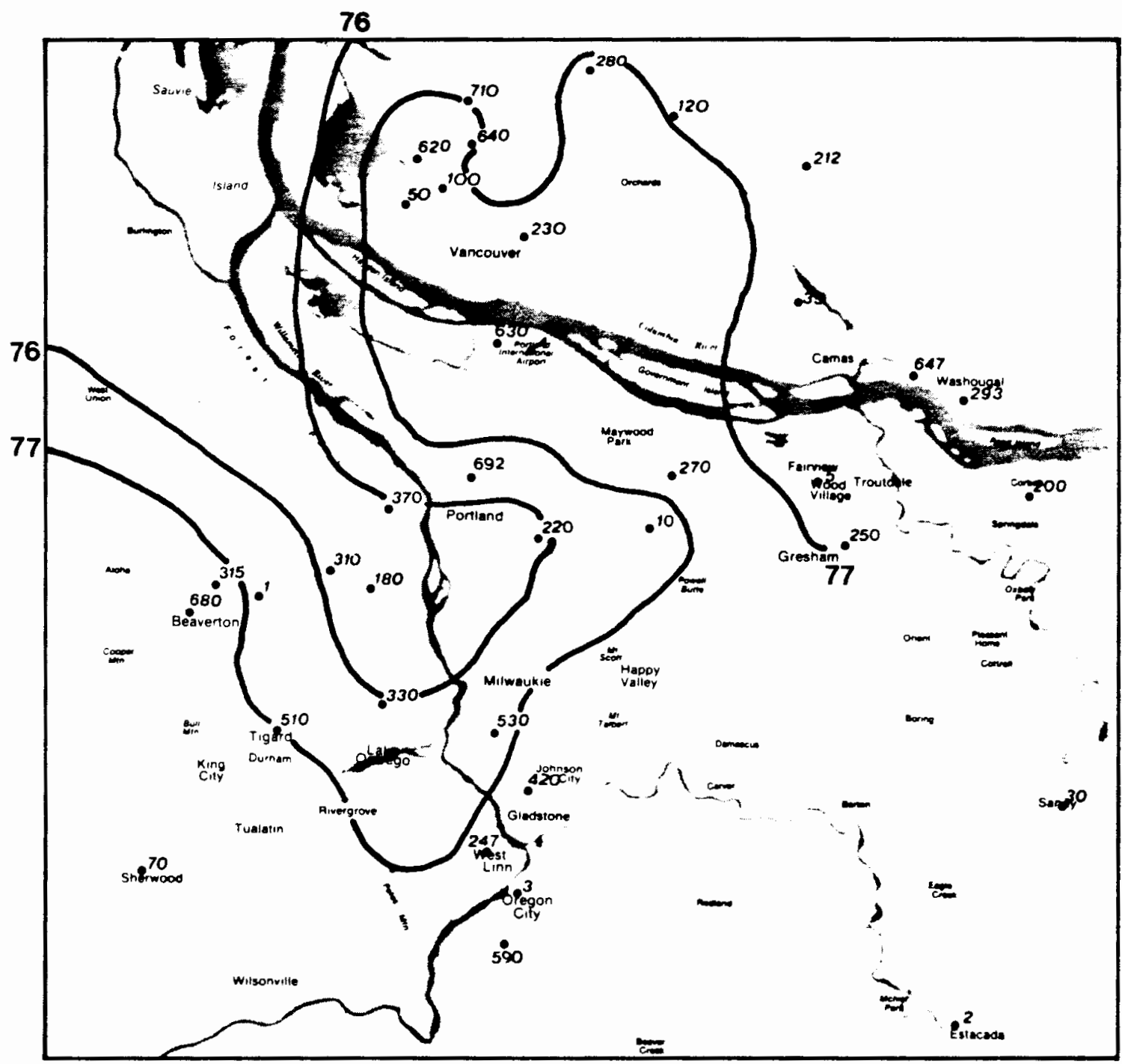

Figure 12-3. Maximum temperature distribution under east wind in Apri1, 1985. 


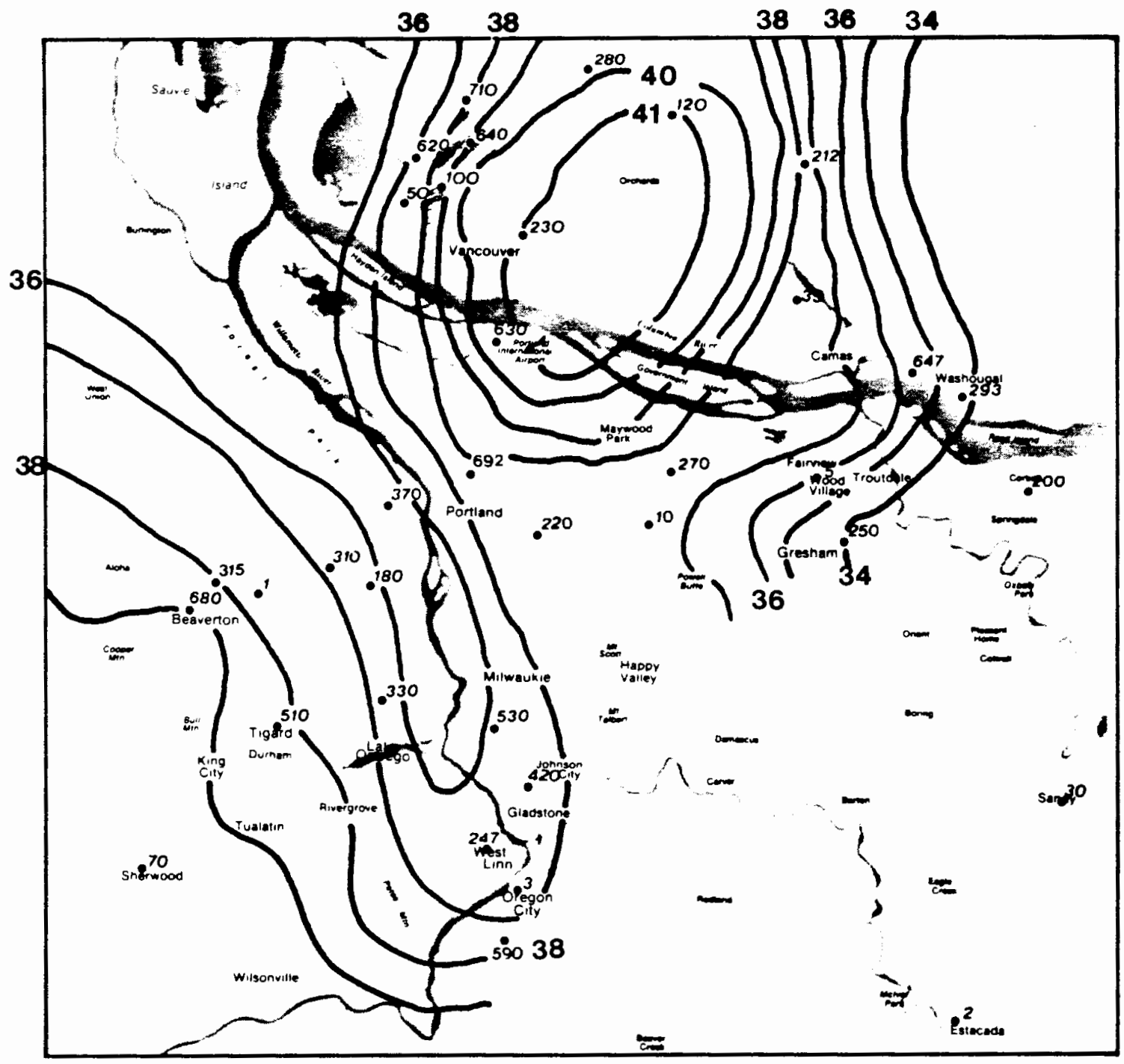

Figure 12-4. Maximum temperature distribution under east wind in January, 1985. 
Under east winds (11-18mph) in January the airflow intensively cools off the area from the mouth of the Columbia Gorge to Troutdale, but its influence is weakened when it passes into the east Portland area (Fig. 12-4). This can be clearly seen by looking at the temperature gradient between Gresham and station 10, and between station 10 and east Portland. The temperature difference of the former is $4^{\circ} \mathrm{F}$, yet only $1^{0}$ $F$ for the latter. In addition, the highest temperature is found near Vancouver, rather than in the city of Portland. Again, this implies that the city of Portland is subject to the cooling effect caused by an east wind, although the urban impact is generally favorable for warmer temperature.

\section{Cloud Cover and Overcast}

Table VIII presents the temperature variations as influenced by cloud cover. Two general features are noted. One is that the magnitude of spatial temperature difference is quite large in all cases. Another is that the location of both maxima and minima in different months is rather consistent. These results suggest that the temperature variation in the Portland metropolitan area is less sensitive to overcast conditions. Three cases were analyzed regarding this assumption.

In July, under the condition of cloud cover $(>8 / 10)$ with winds $(<8 \mathrm{mph})$ in day time, temperature tends to show a pattern similar to that under the influence of northwest winds and clear skies (Figs. 13-1, 13-2). The magnitude of spatial temperature difference during the day is also comparable. This suggests that the presence of the clouds during daytime is a less important factor to the temperature variation 
as compared to the impact of the winds. This result is in agreement with Ackerman's finding in Chicago, where he found for relative strong winds $(>7.8 \mathrm{mph})$ that the cloud cover makes very little difference in spatial temperature difference (Ackerman, 1985). The conclusion in the Portland case is further confirmed by comparing minimum temperature distribution on two days in July; one is overcast with the presence of the northeast wind; the other one is influenced by the northwest wind with the same sky condition. It is clear that they behave quite differently (Figs. 13-2, 13-3). This suggests that it is the wind condition that usually dominates the spatial temperature distribution as well as the magnitude of temperature.

TABLE VIII

TEMPERATURE VARIATION UNDER OVERCAST IN THE PORTLAND AREA, 1985

\begin{tabular}{|c|c|c|c|c|c|c|c|c|c|c|}
\hline & \multicolumn{5}{|c|}{ DAILY MAXIMUM } & \multicolumn{5}{|c|}{ DAILY MINIMUM } \\
\hline & ${ }^{0} \mathrm{~F}$ & SITE & ${ }^{0} \mathrm{~F}$ & SITE & $d t$ & ${ }^{O_{F}}$ & SITE & ${ }^{0} \mathrm{~F}$ & SITE & $d t$ \\
\hline APR & 70 & $\begin{array}{l}\text { East } \\
\text { Portiand }\end{array}$ & 64 & $\begin{array}{l}\text { West Side of } \\
\text { West Hills }\end{array}$ & 6 & 50 & $\begin{array}{l}\text { East } \\
\text { Port } 1 \text { and }\end{array}$ & 42 & $\begin{array}{l}\text { Foothills of } \\
\text { the Cascades }\end{array}$ & 8 \\
\hline JUL & 98 & $\begin{array}{l}\text { East } \\
\text { Portiand }\end{array}$ & 94 & $\begin{array}{l}\text { Foothills of } \\
\text { the Cascades }\end{array}$ & 4 & 63 & $\begin{array}{l}\text { Downtown } \\
\text { Portliand }\end{array}$ & 55 & $\begin{array}{l}\text { Foothills of } \\
\text { the Cascades }\end{array}$ & 8 \\
\hline OCT & 75 & $\begin{array}{l}\text { East } \\
\text { Portland }\end{array}$ & 66 & $\begin{array}{l}\text { Foothilis of } \\
\text { the Cascades }\end{array}$ & 9 & 48 & $\begin{array}{l}\text { East } \\
\text { Portiand }\end{array}$ & 42 & $\begin{array}{l}\text { Foothills of } \\
\text { the Cascades }\end{array}$ & 6 \\
\hline JAN & $\cdots$ & $\cdots$ & -- & -- & - & 32 & $\begin{array}{l}\text { East } \\
\text { Portland }\end{array}$ & 26 & $\mid \begin{array}{l}\text { Foothills of } \\
\text { the Cascades }\end{array}$ & 6 \\
\hline
\end{tabular}

In October, a warm region over the Portland area, both in maxima and minima, was shown under cloudy conditions (Figs. 13-4, 13-5). The value of temperature differential in daytime was $10^{\circ} \mathrm{F}$, and was 6 to $7^{\circ}$ F at night. Similarly, the April case also showed a distinctive spatial 


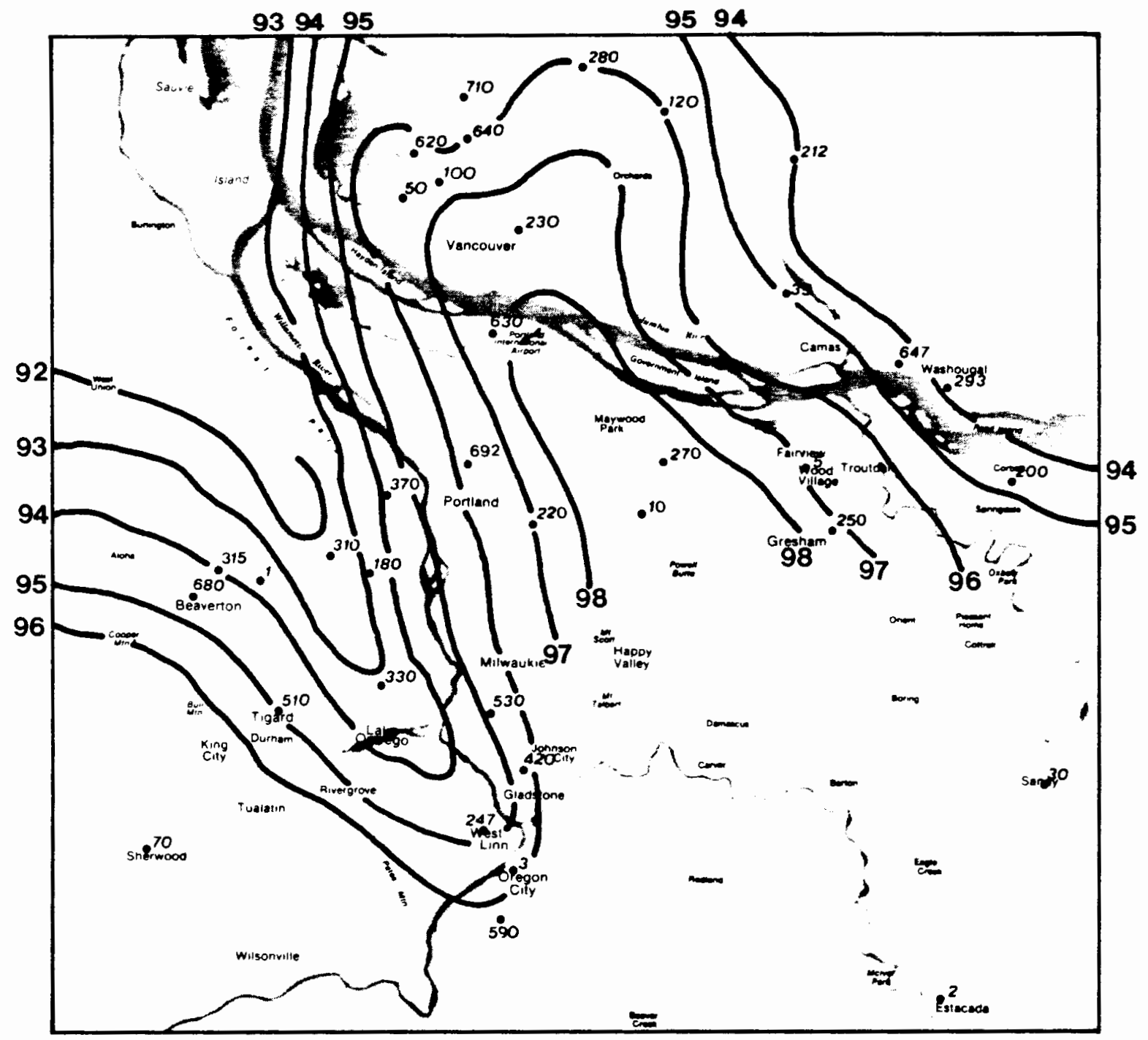

Figure 13-1. Maximum temperature distribution under cloud cover in July, 1985. 


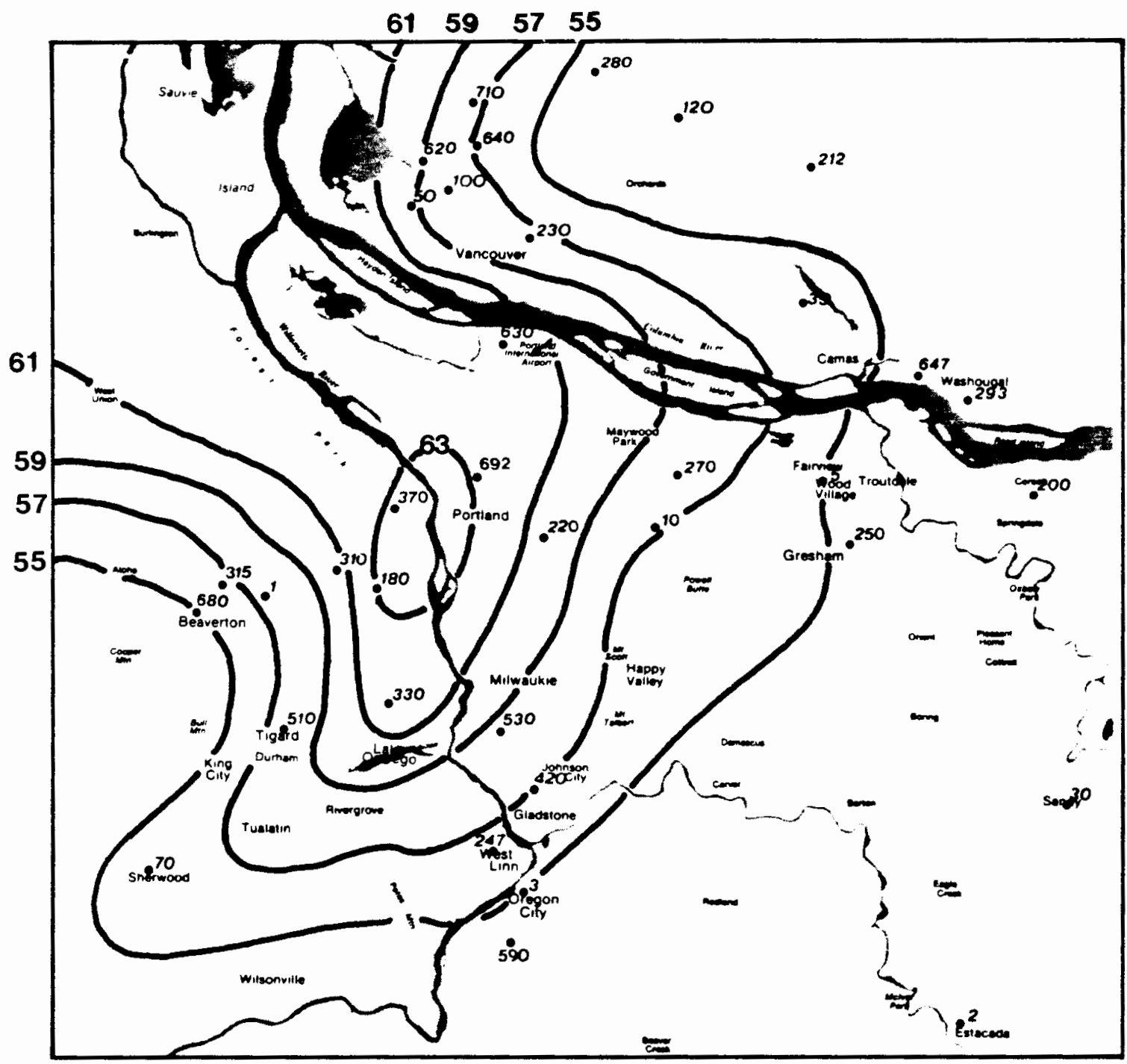

Figure 13-2. Minimum temperature distribution under cloud cover and northeast wind in July, 1985. 


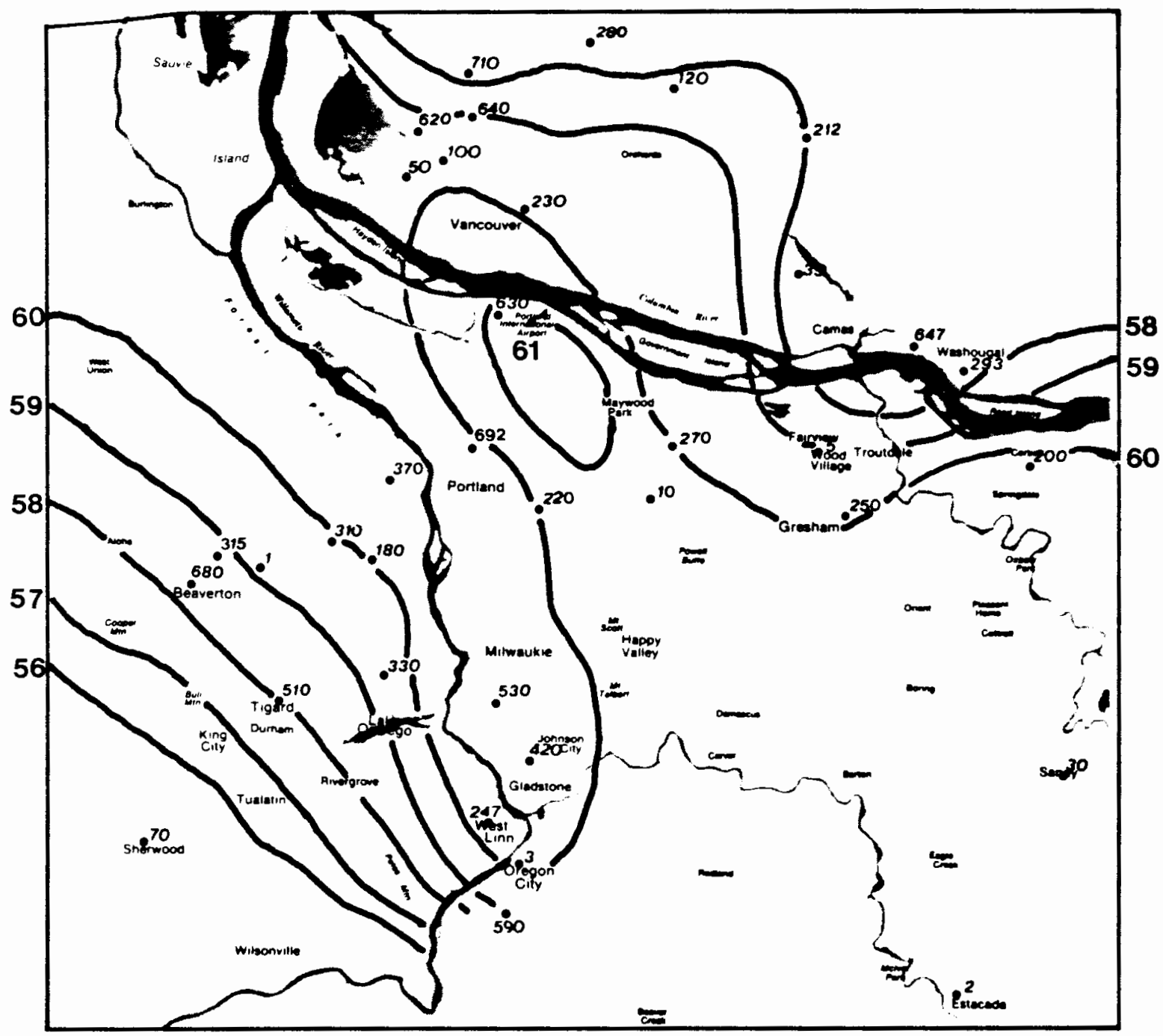

Figure 13-3. Minimum temperature distribution under cloud cover and northwest wind in July, 1985. 


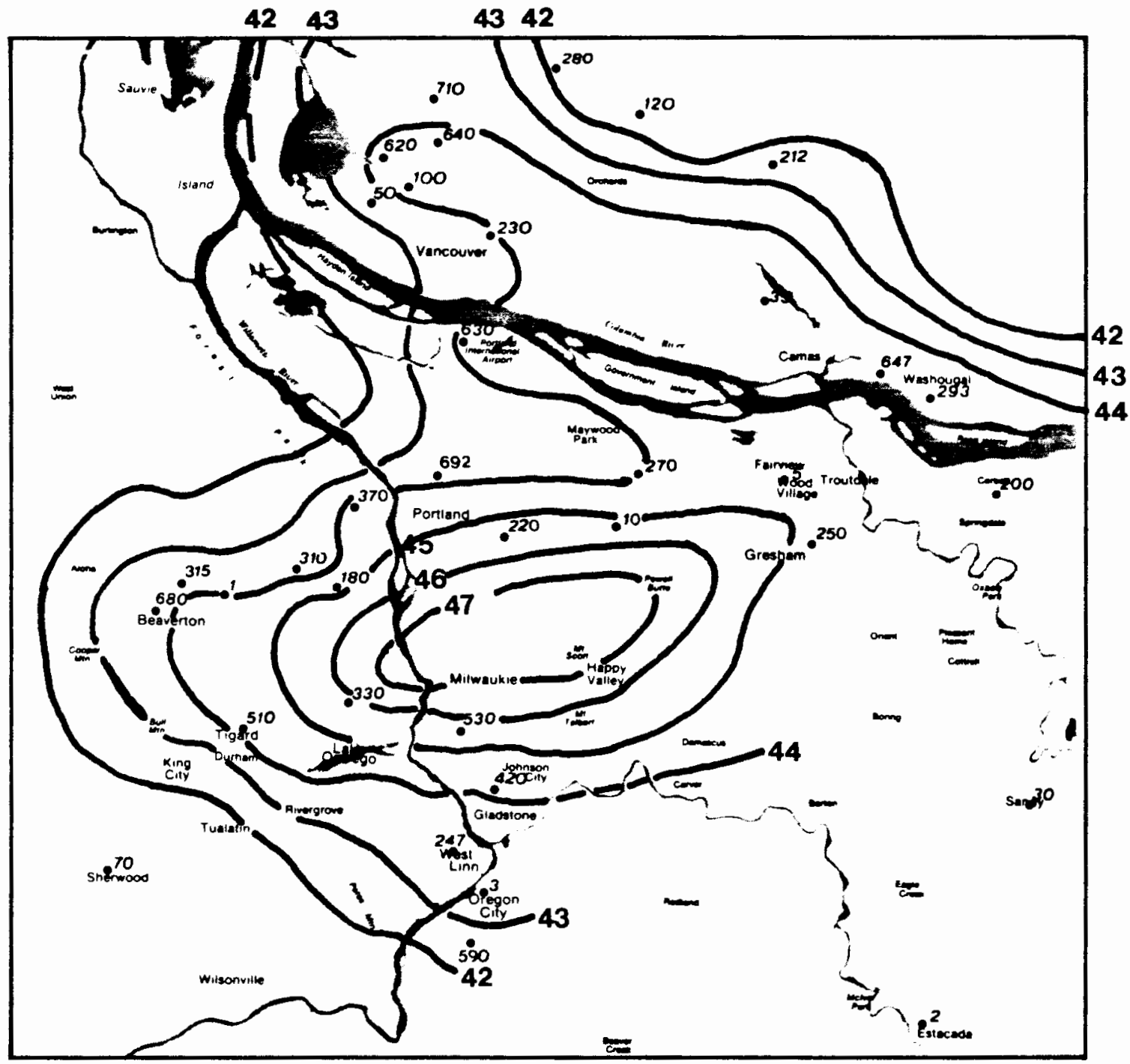

Figure 13-4. Minimum temperature distribution under cloud cover in October, 1985. 


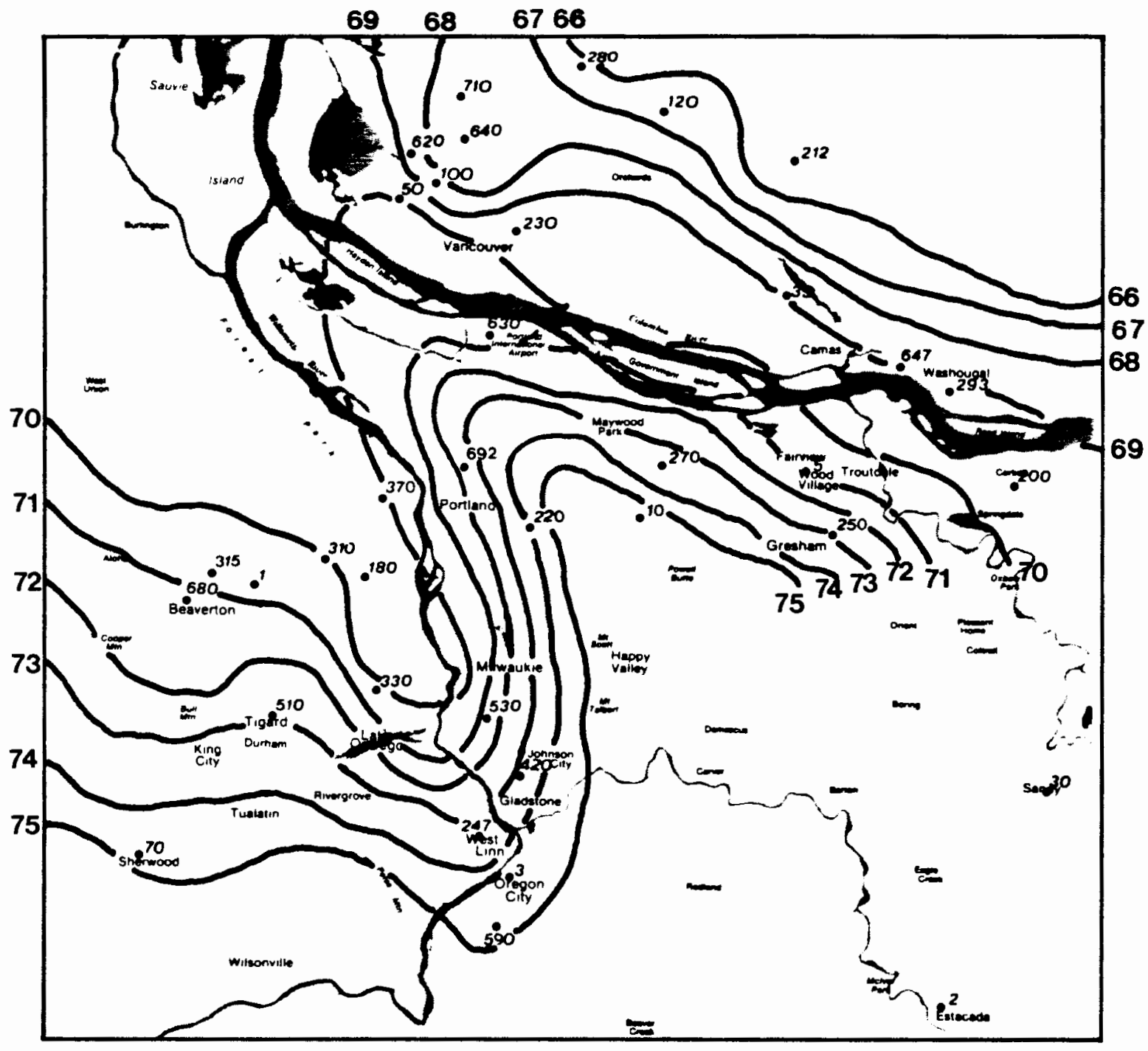

Figure 13-5. Maximum temperature distribution under cloud cover in October, 1985. 
temperature variation. The spatial temperature difference during the day was up to $6^{\circ} \mathrm{F}$, and was more than $10^{\circ} \mathrm{F}$ at $n$ ight, indicating that the influence on temperature by cloud cover is not distinct.

\section{Rainy Conditions}

Another condition that was selected to test for its influence on temperature distribution was rainy days. It was anticipated that the condition would be associated with the occurrence of low surface temperature, smaller diurnal range, and less temperature gradient than the other weather conditions, because of the significant reduction of incoming solar radiation as well as the outgoing longwave radiation.

As shown in Table IX, spatial temperature differences are usually smaller on rainy days than those under other conditions. Also, the magnitude of temperature difference during the day varied little from month to month. It is noted that temperature patterns in April and July showed some deviation from the normal cases, especially so in maximum temperature distribution.

\section{TABLE IX}

TEMPERATURE VARIATION ON RAINY DAYS IN THE PORTLAND AREA, 1985

\begin{tabular}{|c|c|c|c|c|c|c|c|c|c|c|}
\hline & \multicolumn{5}{|c|}{ DAILY MAXIMUM } & \multicolumn{5}{|c|}{ DAILY MINIMUM } \\
\hline & ${ }^{\circ} \mathrm{F}$ & SITE & ${ }^{0} \mathrm{~F}$ & SITE & $d t$ & ${ }^{0} \mathrm{~F}$ & SITE & ${ }^{0} \mathrm{~F}$ & SITE & $d t$ \\
\hline APR. & 55 & $\begin{array}{l}\text { Vancou- } \\
\text { ver }\end{array}$ & 50 & $\begin{array}{l}\text { Foothills of } \\
\text { the Cascades }\end{array}$ & 5 & 43 & $\begin{array}{l}\text { Vancou- } \\
\text { ver }\end{array}$ & 41 & $\begin{array}{l}\text { Foothills of } \\
\text { the Cascades }\end{array}$ & 2 \\
\hline JUL & 70 & $\begin{array}{l}\text { Beaver- } \\
\text { ton }\end{array}$ & 64 & Gresham & 6 & 62 & A irport & 58 & $\begin{array}{l}\text { Foothills of } \\
\text { the Cascades }\end{array}$ & 4 \\
\hline OCT & 63 & $\begin{array}{l}\text { East } \\
\text { Portland }\end{array}$ & 58 & $\begin{array}{l}\text { Foothills of } \\
\text { the Cascades }\end{array}$ & 5 & 52 & $\begin{array}{l}\text { East } \\
\text { Port land }\end{array}$ & 49 & $\begin{array}{l}\text { Foothills of } \\
\text { the Cascades }\end{array}$ & 3 \\
\hline JAN & 44 & $\begin{array}{l}\text { East } \\
\text { Port land }\end{array}$ & 40 & $\begin{array}{l}\text { West side of } \\
\text { West Hilis }\end{array}$ & 4 & $\cdots$ & - & $\ldots$ & -- & - \\
\hline
\end{tabular}


In Apri1, the pattern of maxima generally retains the same characteristics as on clear days. The differences between them is the magnitude of spatial temperature differential and the location of high temperature. For instance, the temperature variation at night is much smaller on rainy days. In addition, during the daytime the highest temperature is seen at Vancouver, Washington, not at Portland (Fig. 14-3). A similar case occurred in July when high temperature was found in Vancouver and Beaverton on a rainy day condition (Fig. 14-2). The reason for these changes is not clear, perhaps due to the variation of local weather conditions.

In January, the maximum temperature on rainy days tends to be evenly distributed. As can be seen in Figure 14-1, the temperature difference during the day was less than $4^{\circ} \mathrm{F}$, the lowest value of the four seasons. This is possibly due to the long rainy period in this time of the year which tends to mask the spatial temperature variation by significantly reducing the solar radiation over a long period of time. As to the minimum temperature, the local influences disturb the spatial pattern significantly so that it is difficult to make generalizations without further observation.

\section{SUMMARY}

An urban heat island exists in the Portland area, with the high temperature being located from Portland to Gresham in all seasons (see Appendix 1). The intensity of the heat island ranges from $4^{\circ} \mathrm{F}$ to $10^{\circ} \mathrm{F}$, 


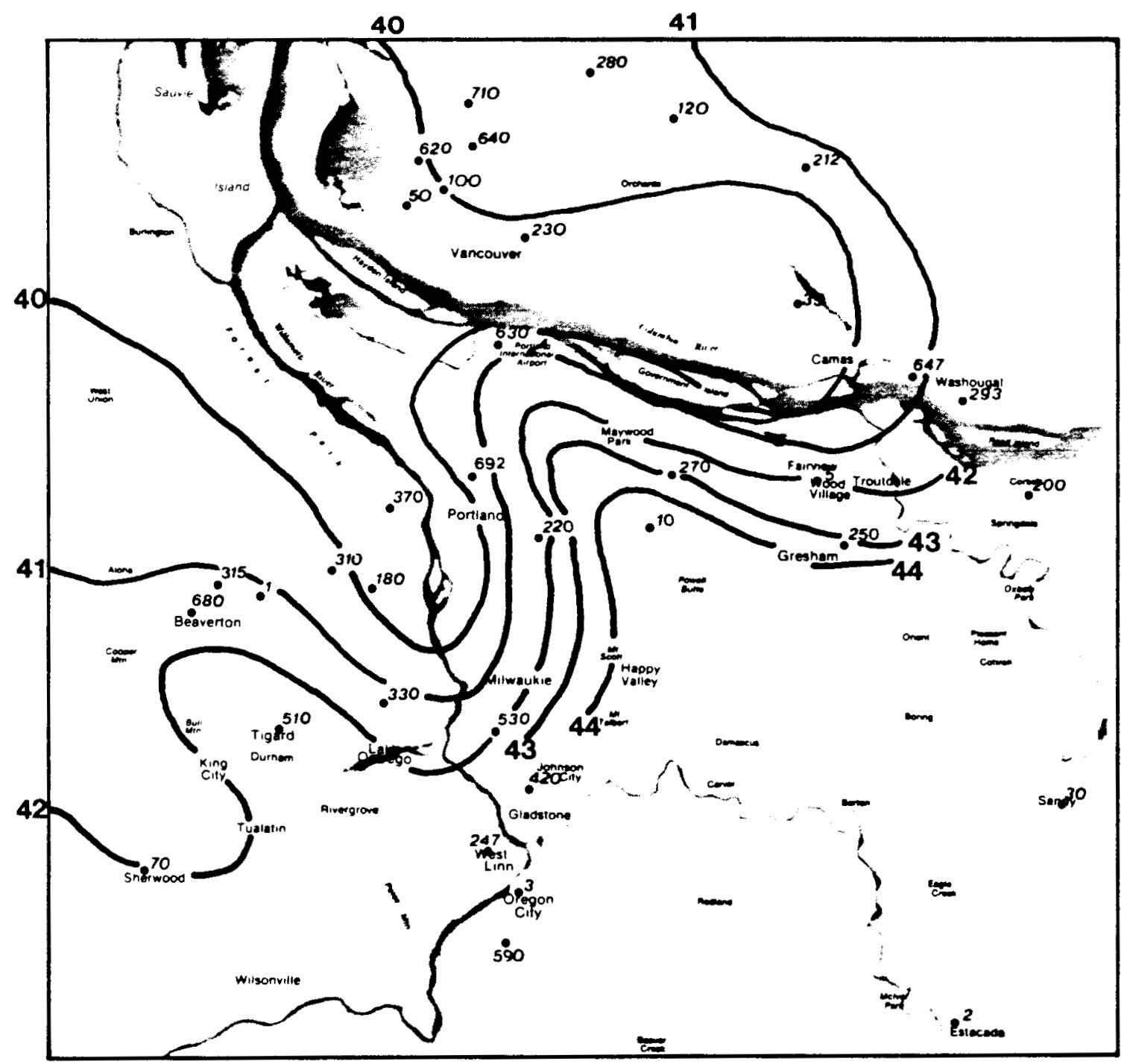

Figure 14-1. Maximum temperature distribution on rainy day in January, 1985. 


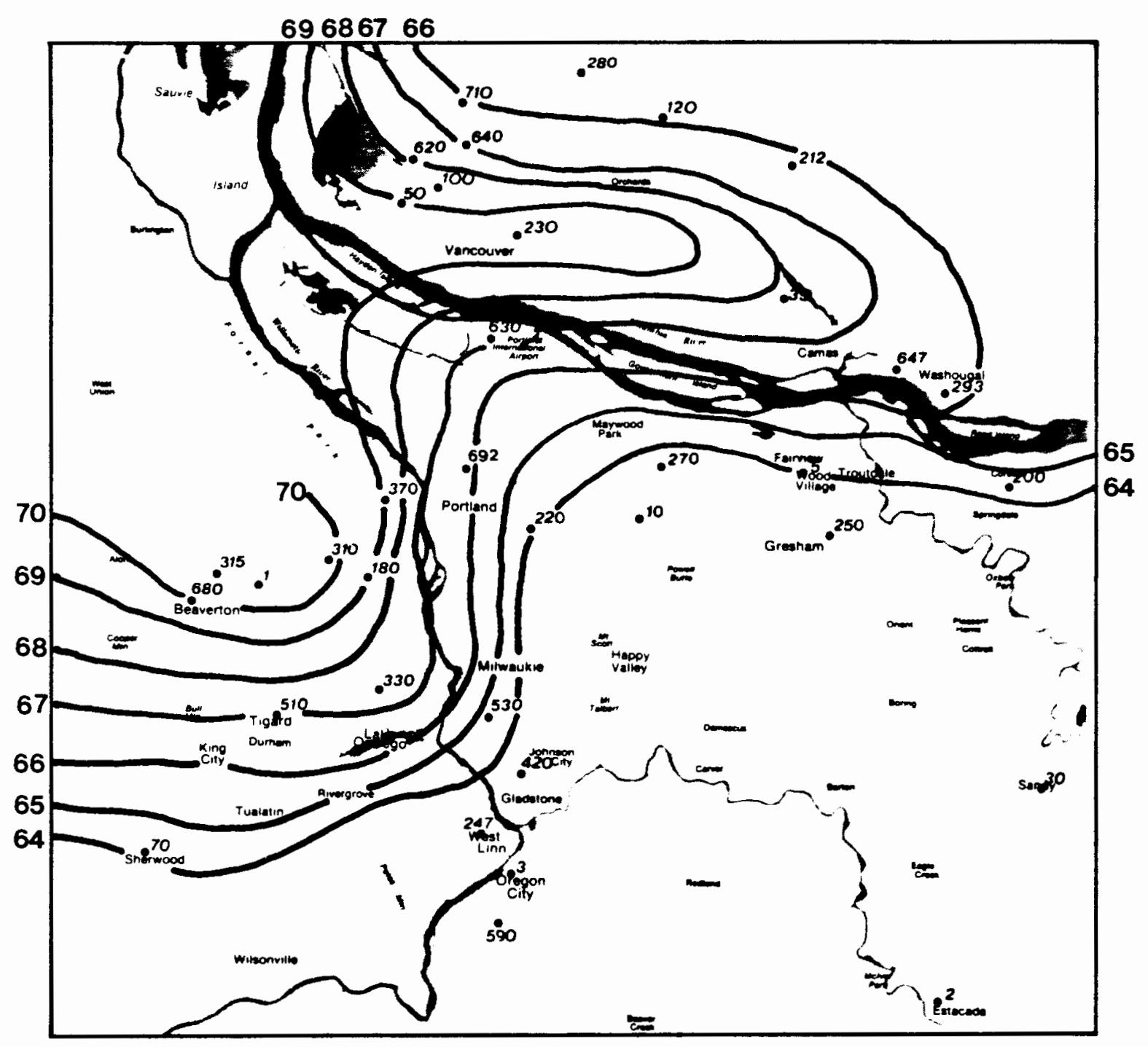

Figure 14-2. Maximum temperature distribution on rainy day in July, 1985. 


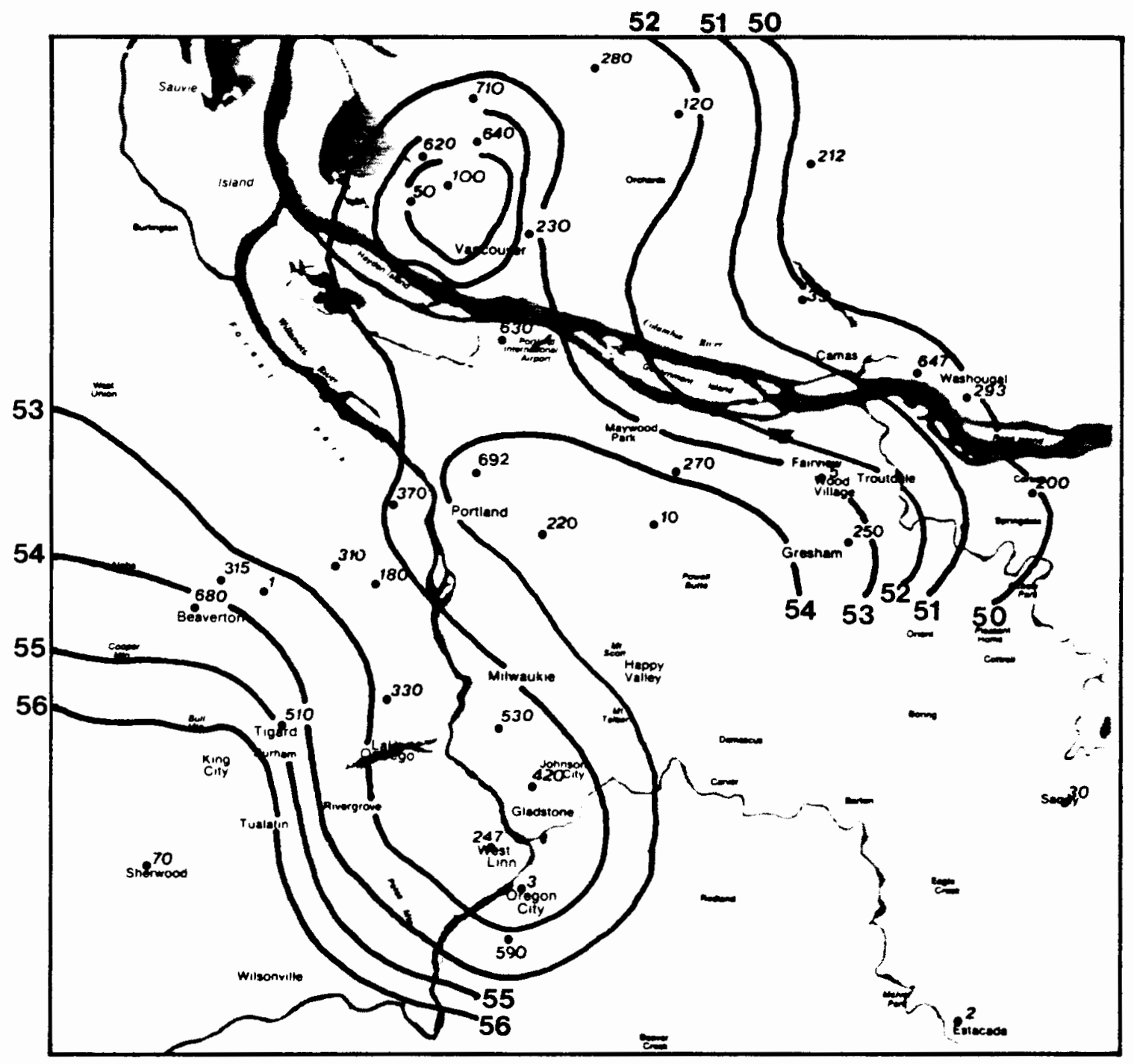

Figure 14-3. Maximum temperature distribution on rainy day in Apri1, 1985. 
these figures represent temperature at only two times during the diurnal cycle; the maximum heat island likely occurs shortly after sunset, and may, in fact, be greater than indicated. The intensity also varies with seasons and months. Under clear skies, the strongest heat island is found in July minimum temperature $\left(10^{\circ} \mathrm{F}\right)$, and the weakest one in April $\left(4^{\circ} \mathrm{F}\right)$. Winter minimum temperatures display the most intense heat is land $\left(7^{\circ} \mathrm{F}\right)$. 
CHAPTER II I

\section{LONG-TERM TEMPERATURE VARIABILITY}

GLOBAL, REGIONAL AND LOCAL TEMPERATURE TRENDS

In order to appreciate the historical pattern of temperature in Portland over the last century, it is necessary to understand the global and regional temperature regime over a corresponding period, since the large-scale temperature pattern is essentially the background upon which regional and local temperature changes occur.

Given this background, it can be asked how Portland's long-term climatic record compares to other locations in the Pacific Northwest and northern hemisphere. Has the unique physical setting and/or urban growth caused Portland's long-term temperature to deviate from regional and hemispheric temperature? If long-term records indicate that the temperature patterns are comparable between the different scales of climate, one may suggest that Portland's climate is essentially a result of large scale climatic change. Conversely, if long-term records indicate substantially different temperature variation between these records, one may attribute these anomalies to local factors such as urban growth.

Data

Three sets of data were used in this analys is and they represent different spatial scales. Surface temperatures for the northern 
hemisphere from 1875-1984 have been most recently processed by Jones, et al. (1986). This was an updated version of a previous data base established in 1982 (Jones and Kelly, 1983). It was corrected to remove inhomogeneities due to station relocations and to the impact of urbanization.

Data for the Oregon coastal division were obtained from the Office of the State Climatologist at Oregon State University. These data, available only since 1931, were used to represent the regional temperature pattern.

For Portland, temperature records from the downtown station exist back to 1871, although the station was moved several times in the early years. Most of the moves were minor, and the station eventually settled at the Custom House downtown where it remained from 1902 to 1973 . This station was closed in 1973, coincident with the opening of the KGW-TV station. KGW-TV station is located downtown at the base of the West $\mathrm{Hills}$, and its temperature regime is strongly influenced by local topography. To blend the two records into one long-term data set, data from the Portland International Airport Station was used to adjust the KGW records, as data recorded at these two sites were highly correlated during the years 1940-1972. In this way, a relatively homogenized data set for Portland Downtown is attained.

In the following section, northern hemisphere, regional, and Portland temperature records will be analyzed. Data for the northern hemisphere and Portland cover the period from 1875 to 1984, while for the Oregon coastal division, data cover the years from 1931 to 1984. 
General patterns of three data sets. Departures of mean air temperature from the 1951-1970 average were calculated for the northern hemisphere, the Oregon coastal division and Portland. For a better recognition of the temperature behavior over time, 10-year running means were computed for each one to filter out high frequency variation (Fig. 15).

The data set for the northern hemisphere illustrates a short period of cooling from 1880 to 1890 , followed by a ten-year period of slight warming. A strong warming trend began around 1910, and peaked in 1940. Then, a trend towards cooling started in 1941 until a subsequent warming trend was initiated in 1973. This is generally in agreement with the aforementioned study by Jones et al. (1986).

Kalnicky (1974) found that the long-term temperature trends of the northern hemisphere were associated with an adjustment of hemispheric circulation from more frequent zonal flow between 1900 and 1950 to more frequent meridional flow since 1950. Regional variation of temperature was largely related to position relative to the upper air westerly wave pattern.

The data set from the Oregon coastal division indicates the occurrence of a cooling trend from about 1940 through 1955, followed by a twenty-year period of great temperature variability. There was no trend in this twenty-year period. An identifiable warming trend did not appear until about 1975; yet, the interannual variability was quite large after 1980 so that the trend was not persistent.

The data set for Portland for the period 1875-1984 exhibits several 


\section{$|\bullet F|$}
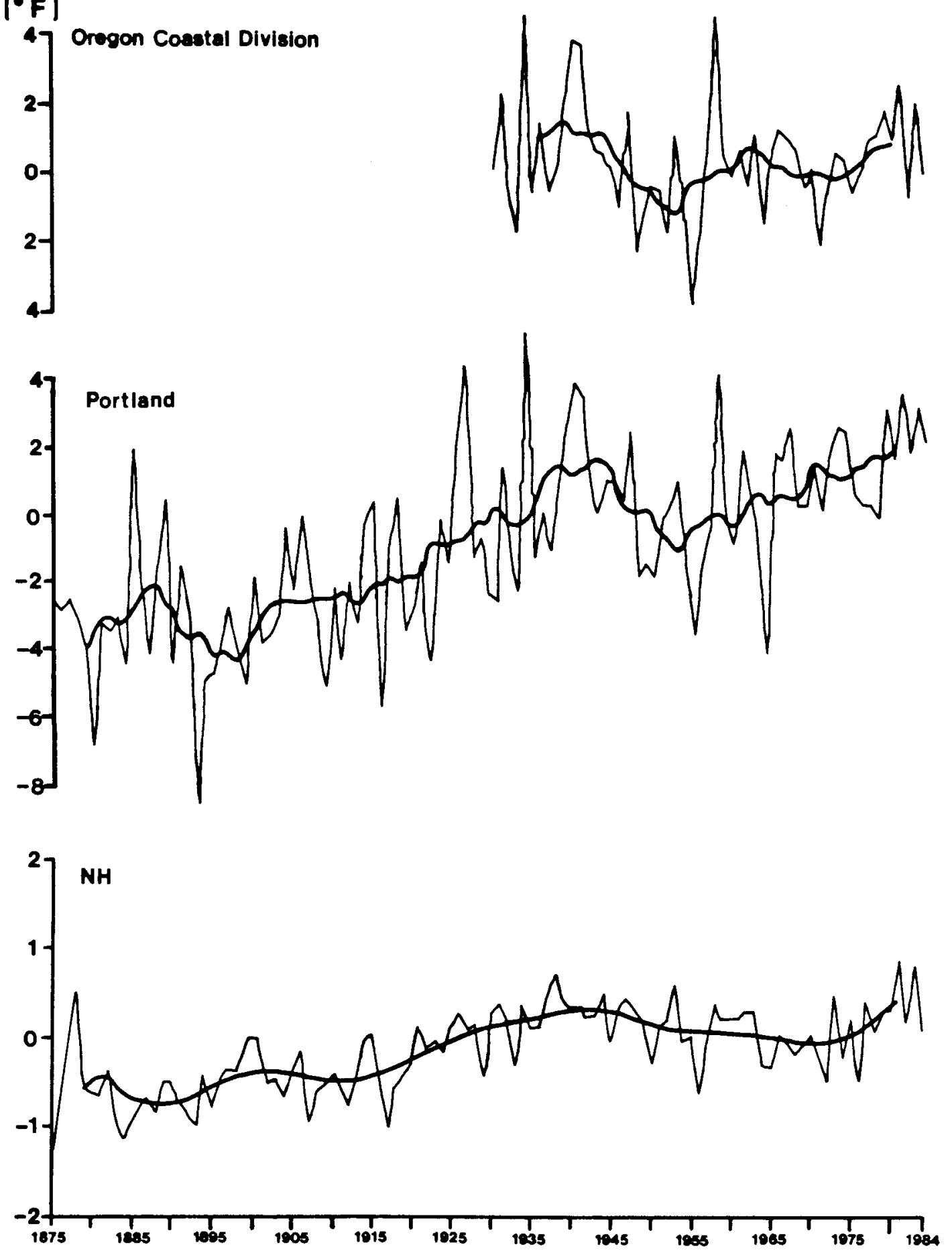

Figure 15. Time series of mean annual temperature departures from normal (1951-1970) for Oregon coastal division, Portland, Oregon, and Northern Hemisphere. 10-year moving average is superimposed on each time series. Northern Hemisphere data are from Jones and Kelly, 1986; other data are from NOAA. 
phases. A slight cooling trend began in 1890 and continued to 1895 . After this a significant warming trend started and lasted until 1940. Cooling began after 1940 and continued to 1955, at which time a warming trend began. This latest warming trend is fairly strong and has persisted to the present.

Comparing the three time series in Figure 15, there is a certain degree of correlation between them. Data sets from both the northern hemisphere and Portland display a general warming trend starting in about 1895 and until 1940, followed by a cooling period to about 1955 (Portland) and 1972 (northern hemisphere) and, finally, a warming trend which began in 1956 (Portland) and in 1973 (northern hemisphere) and persisted to the present. On the other hand, there are also some noticeable differences among these three series. For the northern hemisphere, data from 1955-1973 show that this was a period of steady cooling; for the coastal region, this period shows no apparent trend one way or the other. In contrast to both hemispheric and regional patterns, Portland's data demonstrate a warming trend over the entire period. Another variation is noted in the early warming period during 1900-1940. Portland's pattern displays larger warming rate than the northern hemisphere, although the general pattern of warming is similar.

Temperature Trends. To quantify the observation made from the graph of Figure 15, trends were calculated by 7 inear regression for each of the data sets. Considering the three general periods of warming or cooling shown by the foregoing data analysis, it is reasonable to analyze the temperature trend for each of the three periods for each data set. These periods are: warming from 1900 to 1940, cooling from 
1941 to 1960 , and warming from 1961 to 1984.

Table $x$ shows the computed results. The trends are in $0 \mathrm{~F} / \mathrm{yr}$, and the significance level of the slope is listed. As these three data sets represent a different amount of areal coverage, direct comparison of the statistical results is not valid. However, the magnitude of two warming trends for Portland Downtown itself is quite noticeable. In the first warming period (1900-1940), the trend at Portland was $0.057^{\circ} \mathrm{F} / \mathrm{yr}$. Th is result agrees with Jones and Kelly who documented warming in the United States for the same period of time $(1983, p .245)$. They attributed this to changes in the number of mid-latitude cyclones entering the Arctic and variations in the strength of the continental anticyclones (Jones and Kelly, 1983, p. 246).

\section{TABLE $X$}

MEAN ANNUAL TEMPERATURE TRENDS, 1900-1984

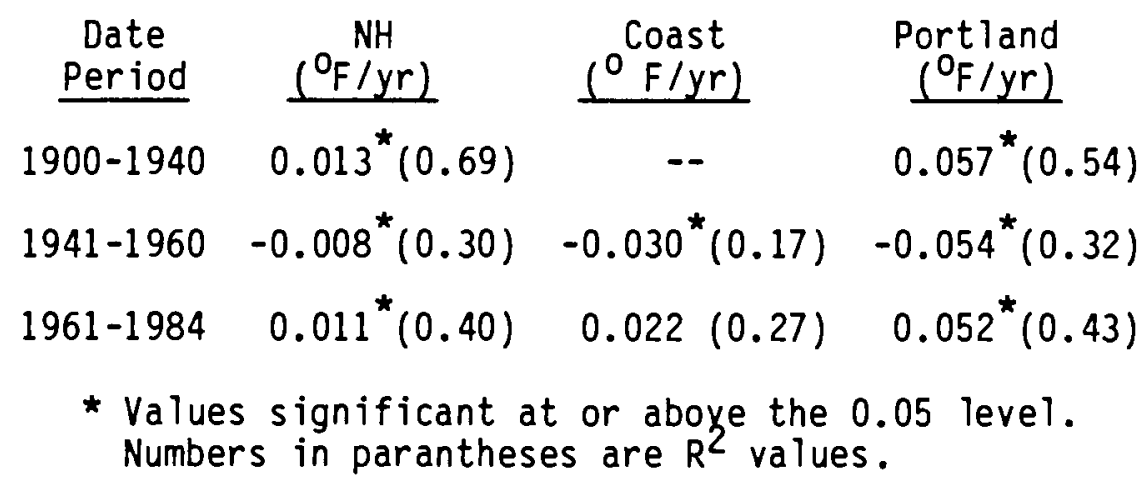

At Portland, the strong warming trend is due partially to the global and regional warming; yet this period is also characterized by the rapid population growth and city expansion. The urbanization should be responsible for this warming to a large extent. This topic will be addressed in the second part of this chapter.

The result associated with the 1941-1960 cooling shows Portland had 
a cooling rate of $0.054^{0} \mathrm{~F} / \mathrm{yr}$ during this period. Also, trends for both the northern hemisphere and coastal division are significant at the 0.05 level.

For the latest warming from 1960-1984, the result shows that Portland displays a decisive warming trend initiated in the late 1950 's. It is noted that the warming trends are not statistically significant for the Oregon coastal division due to large interannual variability in the data. In contrast, the trend for Portland is statistically significant (see also Table $X$ ). It suggests that the air temperature of Portland is determined not only by global and regional climatic controls, but is also influenced by other local factors.

The foregoing analysis of mean annual temperature reflects only a general temperature pattern and obscures much seasonal and monthly detail. To detect the contribution of monthly data to mean annual temperature variation, trends for monthly data for the northern hemisphere and Portland were computed and analyzed.

Table XI lists results calculated from the monthly data during the 1900-1984 period. The northern hemisphere data shows that the general warming trend since the turn of the century is largely due to spring and early summer monthly data. This is not surprising considering that the annual northern hemisphere average is more strongly correlated with late spring and summer temperature than with winter temperature (Jones and Kelly, 1983). Jones and Kelly attributed this seasonal warming in spring and summer to the possible impact of snow and ice cover over middle to high latitudes. In addition, Cess (1982) predicted that the effects of increasing atmospheric carbon dioxide should be most 
significant during this time of the year. Portland monthly data show that persistent warming is also seen for May, June, and July as it is for the northern hemisphere; yet the magnitude of these trends is larger in Portland. There is a difference in other months, however. In Portland, December and February display strong warming trends which are not shown in the hemispheric pattern. The reason underlying these statistics is probably due mainly to regional climatic change. In the upper atmosphere under control of ridges, surface temperature departures are generally positive, partially because the southerly flow on the west side of the ridge advects a warm air mass. It is found that this type of circulation pattern over western North America has occurred more frequently since 1950 than before (Kalnicky, 1974).

\section{TABLE XI}

MONTHLY MEAN TEMPERATURE TRENDS FOR NORTHERN HEMISPHERE AND PORTLAND, $1900-1984$

\begin{tabular}{|c|c|c|}
\hline Month & $\begin{array}{l}\text { Nothern Hem isphere } \\
\text { Trend (OF/yr) }\end{array}$ & $\begin{array}{c}\text { Portland } \\
\text { Trend }\left(0_{F} / \mathrm{yr}\right) \\
\end{array}$ \\
\hline $\begin{array}{l}\text { JAN } \\
\text { FEB } \\
\text { MAR } \\
\text { APR } \\
\text { MAY } \\
\text { JUN } \\
\text { JUL } \\
\text { AUG } \\
\text { SEP } \\
\text { OCT } \\
\text { NOV } \\
\text { DEC }\end{array}$ & $\begin{array}{l}0.001 \\
0.004 \\
0.003 \\
0.006^{\star} \\
0.006^{\star} \\
0.004^{\star} \\
0.003^{\star} \\
0.002 \\
0.002 \\
0.003 \\
0.004 \\
0.005\end{array}$ & $\begin{array}{l}0.011 \text { * } \\
0.029^{*} \\
0.011 \\
0.005 \\
0.017^{\star} \\
0.020^{\star} \\
0.019^{\star} \\
0.014 \text { * } \\
0.031 \\
0.014 \\
0.008 \text { * } \\
0.027^{\star}\end{array}$ \\
\hline
\end{tabular}

Nevertheless, the consistently larger magnitude and longer time span of warming trends shown by the monthly data for Portland reinforce 
the hypothesis that urbanization is one of the important control factors contributing to warming. More detailed examination on local long-term temperature variation and control factors follows.

\section{TEMPERATURE VARIATION AND CONTROL FACTORS}

Growth of Portland

To analyze the influence of major controls on the temporal temperature variation in Portland, a brief examination of Portland's history may provide a useful background. Portland was founded in 1845 and experienced continual population growth from the late 19 th century to the 1970 's. Figure 16 presents the population change in the Tri-County Area (Clackmas, Multnomah, Washington) from 1890 to 1985. Statistics show that population in the area jumped from 105,000 in 1890 to $1,078,000$ in 1910 . The growth rate has been rather large, especially after 1960.

Another indicator of the rate of urbanization is the rapid spatial expansion of the city and its surroundings and the associated change of land-use in suburban areas during this century. Figure 17 illustrates this historical change from the 19 th century to 1975 . The spatial expansion in all directions centered at downtown are clearly seen. The Portland agglomeration grew from three 19th century sites: Fort Vancouver, Oregon City and Portland. By the end of the century the urban population centered on these sites. The largest concentration of people was in the low terrain between the Willamette River and the West Hills around downtown. By 1940, the urban lands of Portland merged with those of Oregon City, Gresham, and the Tualatin Valley. In 1975, the 
Portland urban region spread over 600 square miles. Between 1940 and 1970, the population doubled in the metropolitan area, but the area of the urban lands quadrupled (Patton, 1976). The expansion of the urbanized area has been continuing since 1975 .

The following section will discuss temperature trends at Portland and four other stations in western Oregon, followed by comparisons of these trends for urban versus non-urban stations in order to assess the impact of urbanization and other local controls on temperature variation.

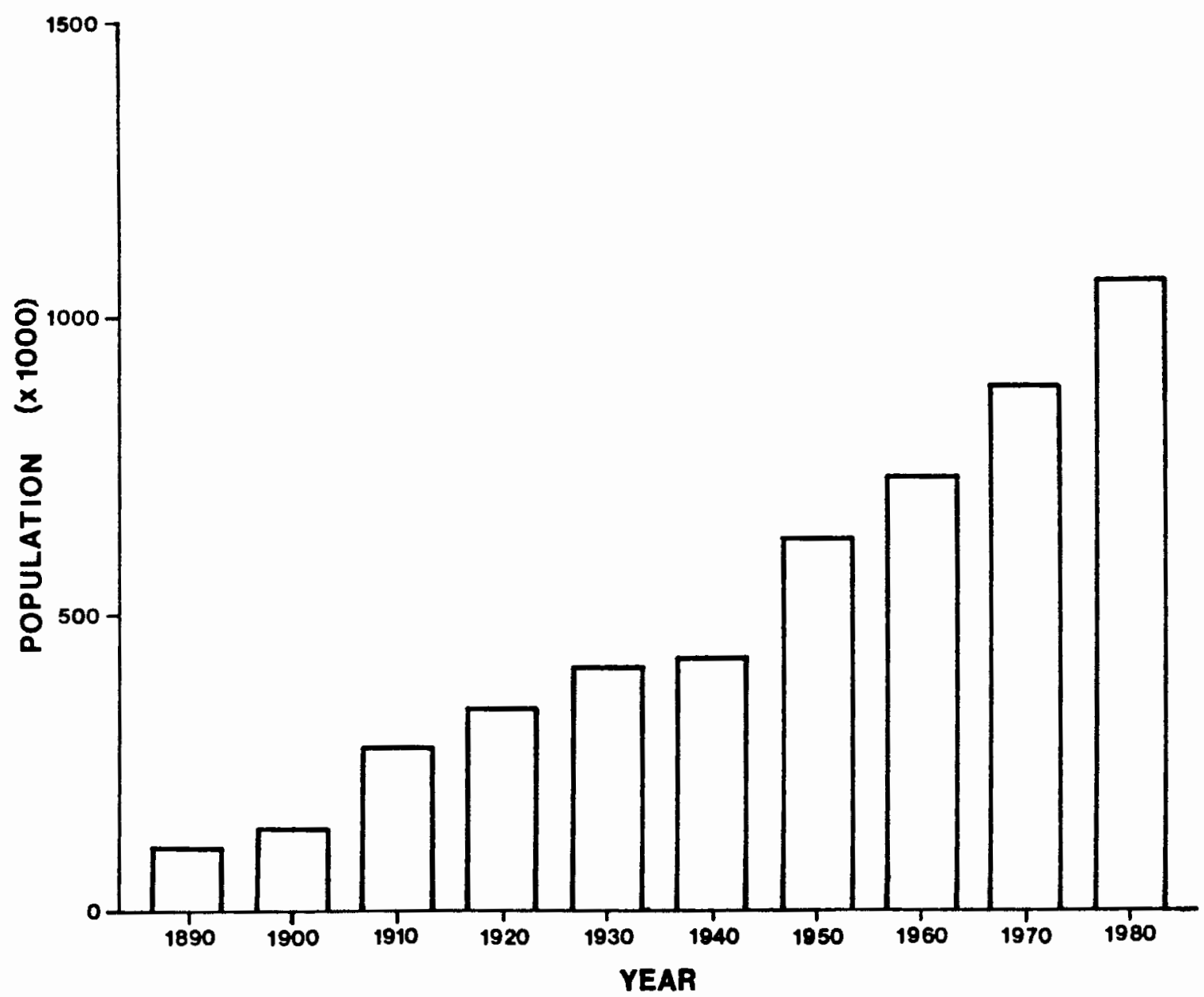

Figure 16. Population Growth of Portland, Oregon, 1890-1980. Data from Eenter for Bopulation Kesearch and Census, Portland State University. 


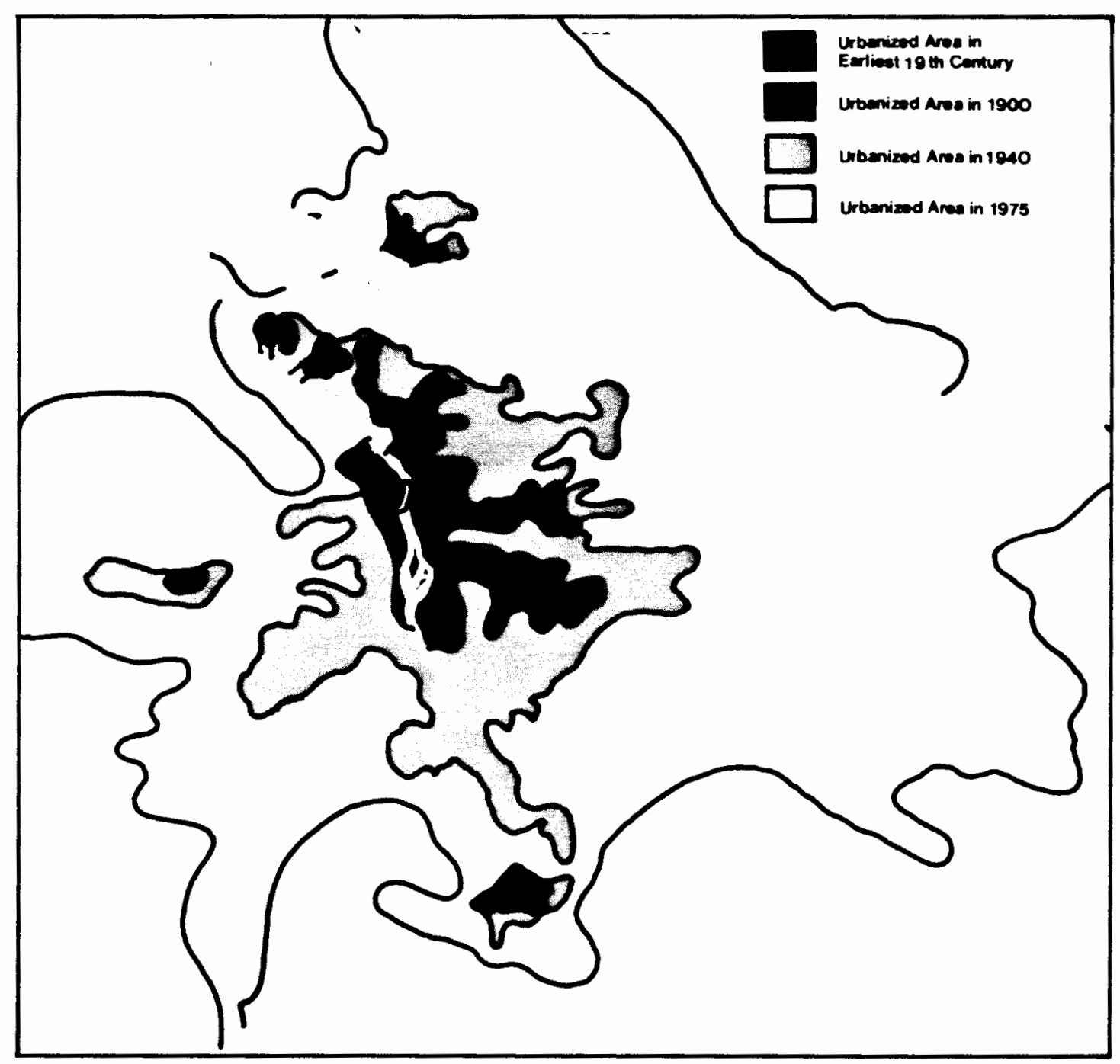

Figure 17. The expansion of Portland urban area. Modified from Patton et al., The At las of Oregon. 


\section{Temperature Trends}

Temperature trends at five selected stations are computed over the period of record for the following variables: mean, maximum, minimum for annual, January, and July (Table XII). It is noted that only Portland Downtown and Portland International Airport stations' data showed some warming trends which are statistically significant at or above the 0.05 level. These warming trends occurred in annual mean and maximum temperatures at Portland Downtown, and in annual maximum, minimum, and July minimum temperatures at the airport station. In contrast, the rest of stations that are located in non-urban areas showed no significant trends, either warming or cooling, over the last half century. For purpose of comparison, Table XII lists the results of all stations.

Among the warming trends, the strongest is seen in July minimum temperature at the airport station, exceeding $0.04^{\circ} \mathrm{F} / \mathrm{yr}$. Also, the mean maximum and minimum temperatures show the trends of $0.033^{\circ} \mathrm{F} / \mathrm{yr}$ and $0.026^{\circ} \mathrm{F} / \mathrm{yr}$, respectively. At Portland downtown, magnitudes of 0.031 and $0.030^{\circ} \mathrm{F} / \mathrm{yr}$ are found in mean annual and maximum temperatures. To revea 1 the true temperature trend due to urbanization at Portland downtown, direct comparison with non-urban stations is necessary.

Method of Comparisons

Figure 18 is a schematic of stations chosen for this analysis. A1l are west of the Cascades, with each one representing a unique combination of physical setting and city size. As shown in the graphic, this network is used to compare three major controls: the impact of urbanization (U); the Columbia Gorge (G); and mountain influence as 


\section{TABLE XII}

LINEAR TEMPERATURE TRENDS FOR SELECTED STATIONS IN WESTERN OREGON

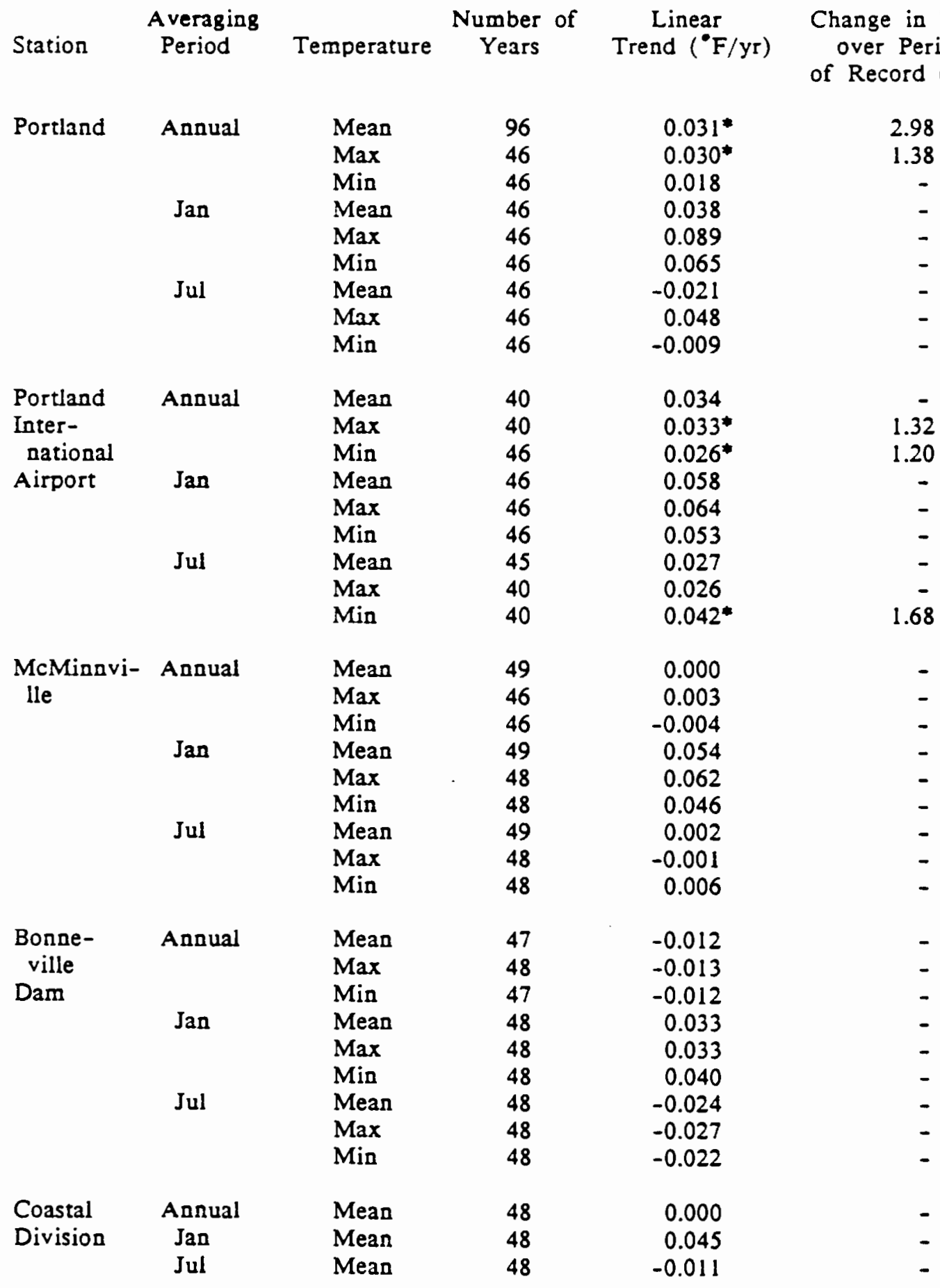

* Values significant at or above the 0.05 level. 


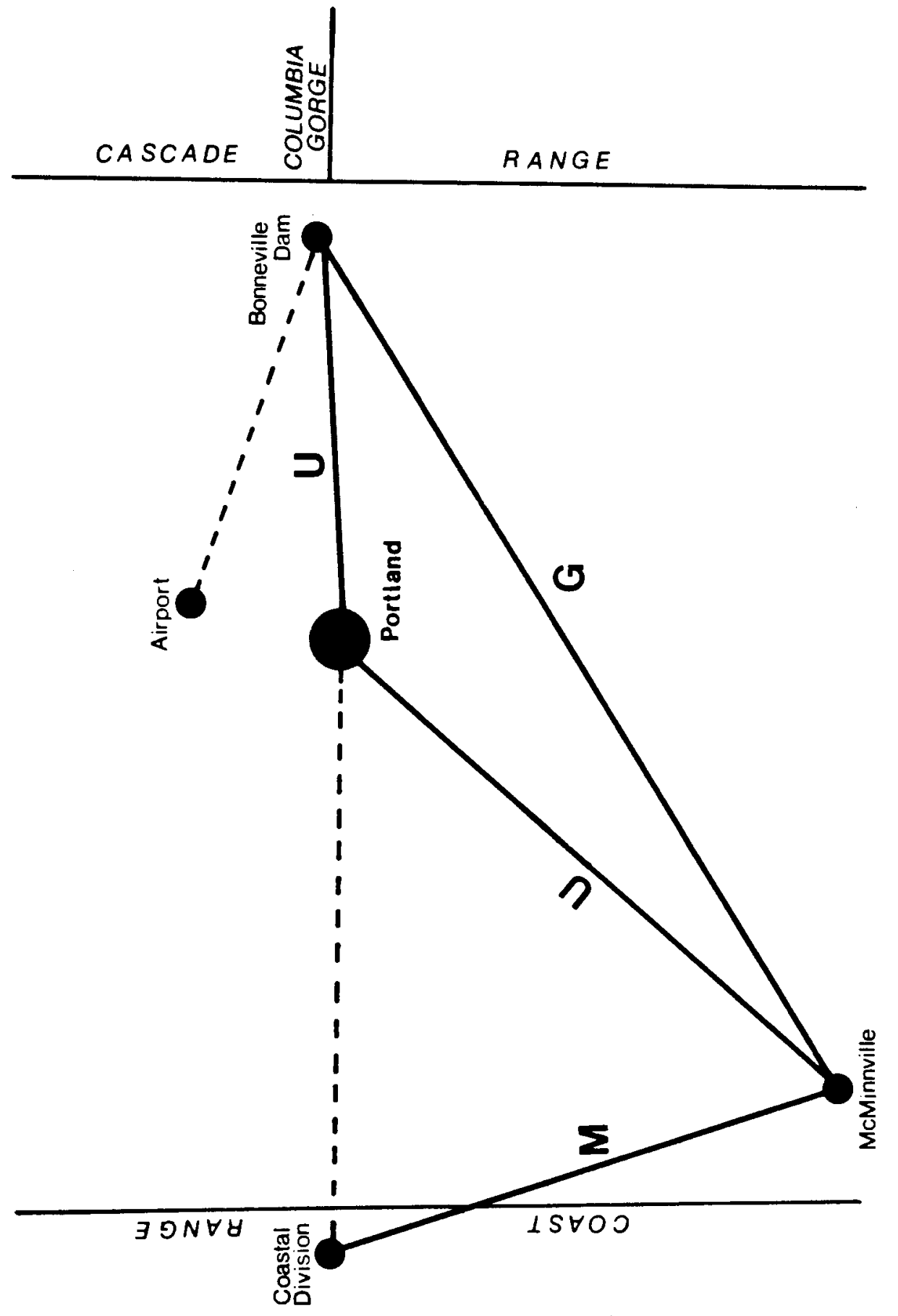

4

○َ

$\stackrel{4}{+}$

\%

농

$=$

E $\frac{0}{5}$

늠

a

穴

$\dot{n}$

ธิ

$+$

里

$\stackrel{\square}{\square}$

을 응

บ

엉

으 동

4 交

늠음

$+=$

E

造

的

क)

온

产.

두 
restricted by Coast Range (M) .

First, the contribution to temperature trend in Portland through urbanization can be identified by comparing Portland downtown with McMinnville and the Bonneville Dam stations, because the latter two sites are essentially not urbanized.

Secondly, to detect the role of the Columbia Gorge on temperature characteristics, Bonneville Dam is contrasted with McMinnville. Bonneville Dam is located directly in the Gorge, while McMinnville, in the middle of the Willamette Valley, is little influenced by the Gorge. Both stations are located in non-urban areas and at a similar elevation. Thus, the major temperature differential between them is attributed to the impact of the Columbia Gorge.

The third comparison is between coastal sites and McMinnville. As these sites are separated by the Coast Range, the temperature differential between them is primarily attributed to the presence of the mountain barrier.

Impact of Urbanization. Two non-urban stations are compared to Portland Downtown. It is noted from the previous result that there are essentially no trends of annual temperature at McMinnville over the period of record (Table XII). In other words, no significant influence on annual temperature is found due to the urbanization at these two sites.

Linear trends of temperature difference between Portland Downtown and McMinnville are listed in Table XIII. The results suggest that Portland's annual mean and maximum temperatures, January mean, July mean and maximum temperatures show warming trends during the last 50 to 90 
years. The most significant rising among all these trends is the July maxima, which is reaching $0.056^{\circ} \mathrm{F} / \mathrm{yr}$. For annual mean temperature, the magnitude of the trend is $0.028^{\circ} \mathrm{F} / \mathrm{yr}$. Another independent comparison was conducted between Portland Downtown and Bonneville Dam. The results are similar to the first comparison, which show the warming trends in Portland in annual mean, maximum, and July maximum. The magnitude of the trends are also comparable to the first comparison. Significant trends are graphed in Figure 19.

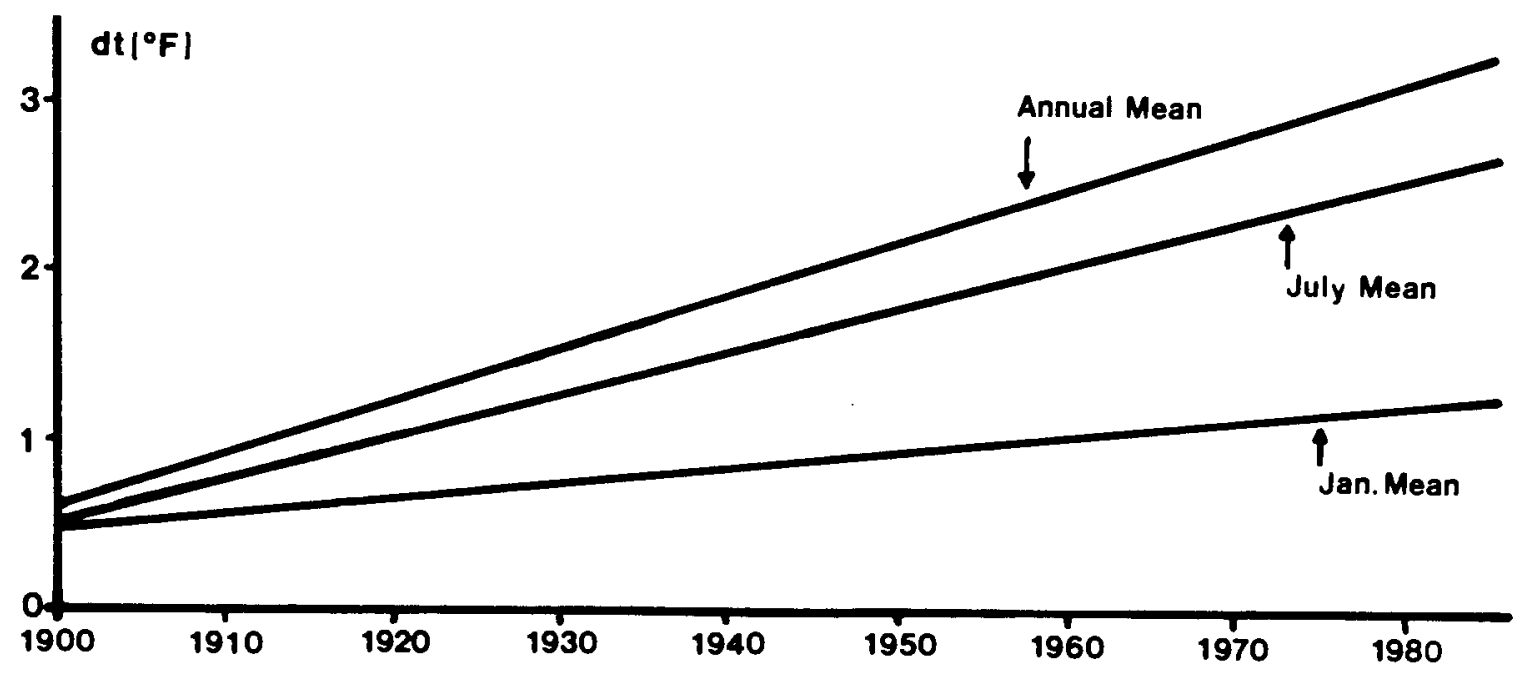

Figure 19. Evolution of temperature differences between Portland Downtown and McMinnville. dt is the magnitude of the temperature difference, Portland minus McMinnville.

From the foregoing analysis, it can be concluded that urbanization in Portland has affected the temperature history. The magnitude of this apparent influence is less than in some larger cities (see Table XIV). In Tucson and San Diego, for instance, the temperature trend is $0.075^{\circ}$ F/yr over the last forty years (Kukla et al., 1986), three times more than in Portland. Nevertheless, the result suggests that in a medium 
sized city like Portland, with rather complex topography, the urban warming effect can still be appreciable.

TABLE XIII

\section{LINEAR TRENDS OF TEMPERATURE DIFFERENCE BETWEEN STATIONS} IN WESTERN OREGON

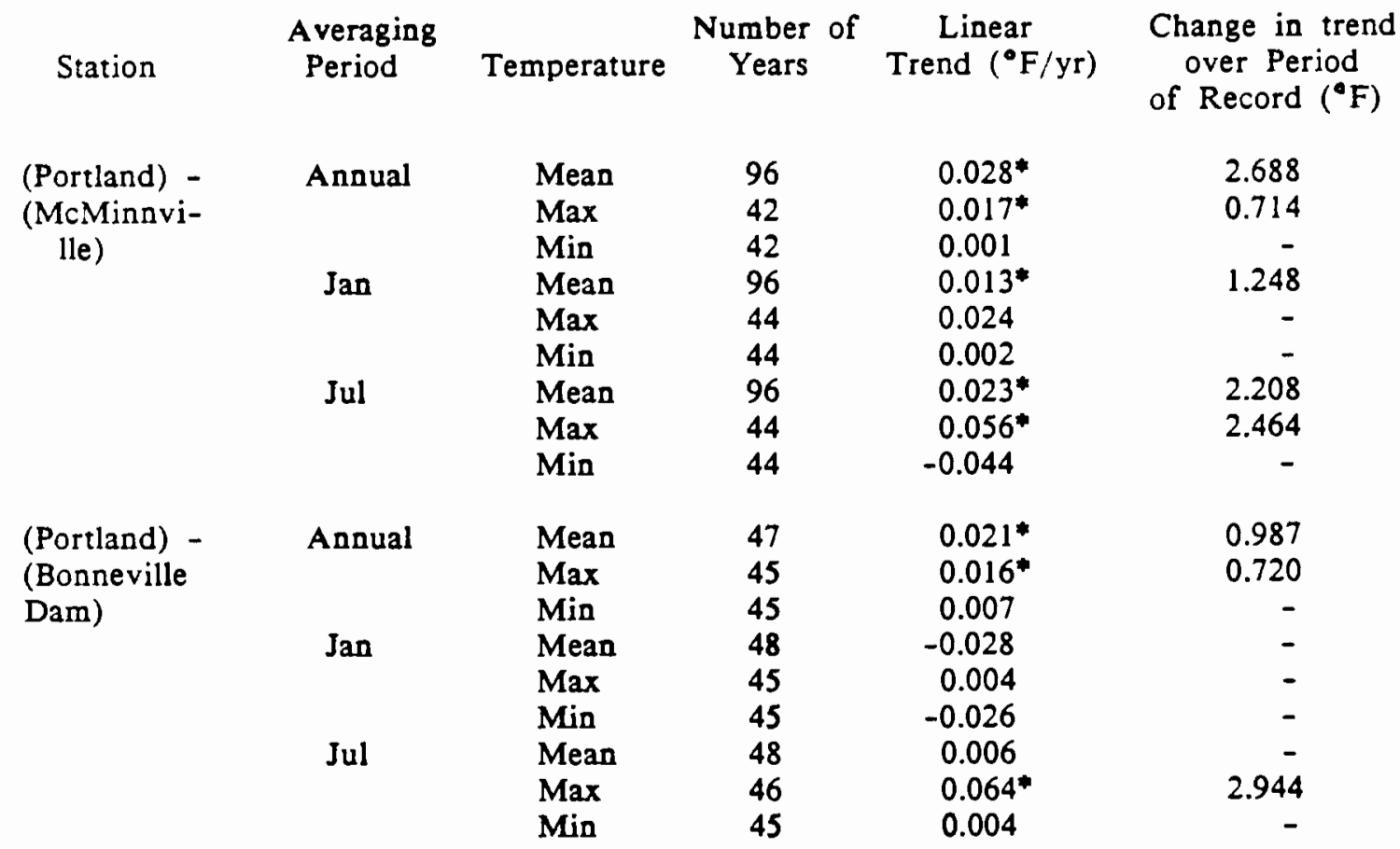

* Values significant at or above the 0.05 level.

Impact of the Columbia Gorge. The impact of the Gorge is assessed by comparing McMinnville with Bonneville Dam. As seen in Table XV, the annual mean temperature at these two sites is very similar $\left(52.2^{\circ} \mathrm{F}\right.$ versus $52.0^{\circ} \mathrm{F}$ ). However, the annual maximum temperature at McMinnville is almost $3^{\circ} \mathrm{F}$ higher than that at Bonneville Dam; this is also the case for January and JuTy maximum temperatures. In contrast, the annual minimum temperature at McMinnville is $3.4^{\circ} \mathrm{F}$ lower than that of Bonneville Dam, indicating that the cooling effect on annual temperature 
caused by the Gorge is noticeable in the day rather than at night. In McMinnville, the lower nightly temperature is probably caused by either airflow from the ocean or the air drainage down the Coast Mountains.

TABLE XIV

COMPARISON OF URBAN WARMING TRENDS

\begin{tabular}{|c|c|c|c|}
\hline Region & Remarks & Interval & $\begin{array}{c}\text { Temperature } \\
\text { Trend }(" \mathrm{~F} / 10 \mathrm{yrs})\end{array}$ \\
\hline Maryland & Baltimor/Woodstock & $1904-1979$ & 0.576 \\
\hline SW U.S. & $\begin{array}{l}\text { Tucson/Airport } \\
\text { San Diego/Scripps }\end{array}$ & $1940-1980$ & 0.756 \\
\hline Argentina & $\begin{array}{l}\text { Buenos Aires/ } \\
\text { Countryside }\end{array}$ & $1920-1950$ & 0.594 \\
\hline Japan & Tokyo & $1936-1965$ & 0.576 \\
\hline France & Paris/Lyon & $1891-1986$ & 0.216 \\
\hline Oregon & Portland/ & $1890-1985$ & 0.280 \\
\hline
\end{tabular}

Source: Fukui, 1970; Kukla et al., 1986; This study.

When looking at the data for monthly mean temperature at these two sites, higher values are seen at the station near the Gorge in July; yet much lower temperatures appear in January. This variation shows the cooling effect by the Gorge in January and warming in July, and is most likely associated with the seasonal alteration of the airmasses in the Willamette Valley and east of the Cascades. Generally, the Columbia Gorge allows more continental air to move in from east; in summer and fall it creates warm and dry weather near the Gorge; in winter it causes lower temperature along the Gorge area.

Impact of the Coast Mountains. Comparing McMinnville with the Coastal division data, the difference of annual mean temperature is only $0.5^{\circ} \mathrm{F}$; this is not surprising as the town of McMinnville is only about forty miles east of the coast. On the other hand, as the Coast 
Mountains separate the coastal plain from the Willamette Valley, the differential of monthly mean temperatures between these two locations is expected. Table XVI shows the distinct variation of January and July mean temperatures between these two sites. In the coastal region, the January mean is $3.7^{\circ} \mathrm{F}$ warmer than that of McMinnville. In July, the opposite temperature is true; i.e., Mcminnville is $5^{\circ} \mathrm{F}$ higher than the coast region. This variation is due partially to the marine influence on the coast, and partially to the impact of the Coast Range, which does weaken the marine air influence on Willamette valley, resulting in a larger range of temperature variation in areas east of the Coast Range.

TABLE XV

COMPARISON OF TEMPERATURE BETWEEN BONNEVILLE DAM AND MCMINNVILLE

\begin{tabular}{|c|c|c|c|c|c|c|c|c|c|}
\hline \multirow[b]{2}{*}{ Averaging Period } & \multicolumn{3}{|c|}{ Bonneville Dam } & \multicolumn{3}{|c|}{ McMinnville } & \multicolumn{3}{|c|}{ Difference $(B-M)$} \\
\hline & $\begin{array}{l}\text { Mean } \\
\left({ }^{\circ} \mathrm{F}\right)\end{array}$ & $\begin{array}{l}\operatorname{Max} \\
\left({ }^{\circ} \mathrm{F}\right)\end{array}$ & $\begin{array}{l}\text { Min } \\
\left({ }^{\circ} \mathrm{F}\right)\end{array}$ & $\begin{array}{l}\text { Mean } \\
\left({ }^{\circ} \mathrm{F}\right)\end{array}$ & $\begin{array}{l}\text { Max } \\
\left({ }^{\circ} \mathrm{F}\right)\end{array}$ & $\begin{array}{l}\text { Min } \\
\left({ }^{\circ} \mathrm{F}\right)\end{array}$ & $\begin{array}{l}\text { Mean } \\
\left({ }^{\circ} \mathrm{F}\right)\end{array}$ & $\begin{array}{l}\operatorname{Max} \\
\left({ }^{\circ} \mathrm{F}\right)\end{array}$ & $\begin{array}{l}\text { Min } \\
\left({ }^{\circ} \mathrm{F}\right)\end{array}$ \\
\hline Annual & 52.2 & 60.3 & 44.1 & 52.0 & 63.3 & 40.7 & 0.2 & -3.0 & 3.4 \\
\hline January & 36.6 & 41.6 & 31.9 & 38.6 & 44.9 & 32.2 & -2.0 & -3.3 & -0.3 \\
\hline July & 67.4 & 78.3 & 56.5 & 65.7 & 82.5 & 48.8 & 1.7 & -4.2 & 7.7 \\
\hline
\end{tabular}

TABLE XVI

COMPARISON OF TEMPERATURE BETWEEN OREGON COASTAL DIVISION AND MCMINNVILLE

$\begin{array}{cccc}\text { Averaging Period } & \frac{\text { Coastal Division }}{\text { Mean }\left({ }^{\circ} \mathrm{F}\right)} & \frac{\text { McMinnville }}{\text { Mean }\left({ }^{\circ} \mathrm{F}\right)} & \frac{\text { Difference }}{(\mathrm{C}-\mathrm{M})} \\ \text { Annual } & 51.6 & 52.0 & -0.4 \\ \text { January } & 42.3 & 38.6 & 3.7 \\ \text { July } & 60.6 & 65.7 & -5.1\end{array}$


CHAPTER IV

DISCUSSION AND SUMMARY

SUMMARY OF RESULTS

The urban heat island is a reflection of the microclimatic changes brought about by an altered radiation budget of the urban surface. It is also modulated by a series of variables including the extent of urban development, characteristics of the local landscape, and different meteorological conditions.

In Portland, the compact mass of buildings and paved roads caused an alteration of the natural landscape, and the activities of its inhabitants are also a major source of heat. These factors account for the temperature difference between the city and its surrounding areas. In addition, the unique topographic and the local weather conditions also affect the occurrence, intensity, and the spatial pattern of the heat island in Portland Metropolitan Area.

Spatial temperature patterns revealed by this study in Portland and its surroundings illustrate the following characteristics:

1. The dominant control factors on seasonal temperature distribution are local topography, elevation, and urban-rural differences in surface structure. The presence of the West Hills accounts for the occurrence of lower temperature in its adjacent area. Cold air drainage from the Coast and Cascade Mountains, along with rapid cooling in the non-urban area is responsible for the large diurnal range 
of temperature at nearby places. In the city area, the low elevation and unique surface structure make its temperature higher than in surrounding areas in all seasons.

2. A heat island exists in the Portland area, with the high temperature being located from eastern downtown Portland to Gresham. The intensity of the heat island ranges from 4 to $10^{\circ} \mathrm{F}$, although this value is not the maximum heat island during a day. The intensity also varies with the season and with the month. Under clear skies, the strongest heat island is found in July minimum temperature $\left(10^{\circ} \mathrm{F}\right)$, and the weakest one occurs in April $\left(4^{\circ} \mathrm{F}\right)$. For seasonal changes, winter minimum temperature displays the most intense heat is land effect $\left(7^{\circ} \mathrm{F}\right)$. In contrast to the heat island, a negative heat island does not show in seasonal mean temperatures, although it occurred on some individual days.

3. Under clear skies and light winds, the intensity of the heat is land is generally stronger than under other weather conditions. However, there is variation from this general situation in April.

4. Spatial temperature distribution is affected by winds. In April and July, wind tends to reduce spatial temperature variation more than it does in october and January. The locations of maximum and minimum temperature are closely related to the wind direction in most of the year, because oceanic and continental winds are quite different in nature.

5. Rainfall tends to smooth out the temperature differential over the area, paticularly for minimum temperature. Also, the sites in which maxima and minima occur change distinctively under rainy conditions. In 
contrast, temperature variation is much less sensitive to overcast conditions, both in the magnitude of spatial temperature difference and the alteration of locations where maxima and minima occur.

The study of long-term temperature over the last century shows that the magnitude of Portland's mean annual temperature trends are $0.057^{\circ}$ $\mathrm{F} / \mathrm{yr}$ and $0.052^{\circ} \mathrm{F} / \mathrm{yr}$ in the two warming periods 1900-1940 and 1961-1984. The results are statistically significant at the 0.05 level. Analys is of monthly data suggests that these warming trends are largely contributed by monthly data in spring and early summer as well as in winter months except January.

Comparisons between Portland and other local non-urban climate stations show that no secular regional trends are found in mean annual temperature for the entire data period from 1875-1984. The Portland Downtown station, however, shows a general warming trend since the end of the last century, $0.028^{\circ} \mathrm{F} / \mathrm{yr}$ in the mean annual temperature and $0.017^{\circ} \mathrm{F} / \mathrm{yr}$ in maximum temperature after the regional trends are removed. Monthly mean temperatures in July and January demonstrate a warming by $0.023^{\circ} \mathrm{F}$ and $0.015^{\circ} \mathrm{F} / \mathrm{yr}$ at Portland, respectively. It is also noted that July maximum temperature shows a significant warming trend by $0.056^{\circ} \mathrm{F}$ during the period from 1940-1985. All these warming trends are due mainly to the impact of urbanization.

The effect of local topography on temperature, mainly by the Columbia Gorge and the Coast Range, is identified. It has been found that cooling due to the presence of the Gorge is noticeable in daytime. This is shown by both annual and monthly maximum temperatures, and the magnitude of temperature difference between a Gorge station and a 
station in the Willamette Valley is $3^{0}$ to $4^{0} \mathrm{~F}$. For monthly mean temperature, higher values are recorded at the station near the Gorge in July, while lower temperature appears in January. The difference is due to the influence of continental air masses and their seasonal change east of the Cascades. The coast Range is a divide of temperature distribution between the coastal margin and the Willamette valley. Stations on the coast generally show smaller ranges of temperature than stations east of the mountains. In McMinnville, the temperature is $1.5^{\circ}$ $\mathrm{F}$ higher than at the coastal stations in July, and $3.7^{\circ} \mathrm{F}$ lower in January, indicating that the Coast Range is a barrier to the strong marine air influence.

\section{SUGGESTED FUTURE RESEARCH}

The performance of this study on long-term temperature variability was limited to Portland and some of the stations in western Oregon. To further understand the variation of urban climate, more city stations with relatively complete and accurate data sets in the Pacific Northwest should be compared with the city of Portland. This can help to identify temperature fluctuations and trends caused by urbanization over the region, and probe into the mechanism of climatic change in cities.

For spatial temperature variation, longer period records will be helpful in terms of delineating the spatial temperature pattern. As the Portland local network has been collecting temperature data for five years, these data are valuable to check the results from this study, and will provide more information for both urban heat islands and other temperature characteristics. An alternative way to study the city's 
spatial temperature is to use remote sensing data. The advantage of this approach is that the synoptic temperature pattern can be captured over both urban and rural areas. In addition, the data resolution is relatively high, and so is the precision. As these data are usually in both digital and image format, more information related to the city's thermal characteristics can be derived.

Finally, the study of long-term climatic change in urban areas requires data for many $c l$ imatic parameters besides temperature. Other parameters, such as preciptation, radiation, and wind are essential for more in-depth and comprehensive study of a city's climate. 


\section{REFERENCES}

Ackerman, B. 1985, "Temporal March of the Chicago Heat Island," Journal of Applied Meteorology, v. 24, pp. 547-553.

Ange 11, J.K. et a 1. 1973, "Urban Influences on a Strong Daytime Air Flow as Determind from Tetroon Flights," Journal of Applied Meteorology, v. 12, pp. 924-936.

Atkinson, B.W. 1983, "Numerical Modelling of Thermally Driven Meso-Scale Airflows Involving the Planetary Boundary Layer," Progress in Physical Geography, v. 3, pp. 229-245.

-.-.-., 1985, The Urban Atmosphere, Cambridge University Press, 1985, $89 \mathrm{pp}$.

Atwater, M.A. 1971, "The Radiation Budget for Polluted Layers of the Urban Environment," Journal of Applied Meteorology, v. 10, pp. 205-214.

----. 1975, "Thermal Changes Induced by Urbanization and Pollution," Journal of Applied Meteorology, v. 14, pp. 1061-1071.

Auer, A.H. Jr. 1978, "Correlation of Land-Use and Cover with Meteorological Anomalies," Journal of Applied Meteorology, v. 17, pp. 636-643.

Barnett, T.P. 1978, "Estimating Variability of Surface Air Temperature in the Northern Hemisphere," Monthly Weather Review, v. 106, pp. 1353-1367.

Bergman, K.H. and E.D. O'Lenic. 1986, "Seasonal C1 imate Summary." Monthly Weather Review, v. 114, pp. 2246-2254.

Bornstein, R.D. 1968, "Observations of the Urban Heat Island Effect in New York City," Journal of Applied Meteorology, v. 7, pp. 575-582.

. 1975, "Two-Dimensional URBMET Urban Boundary Layer Model," Journal of Applied Meteorology, v. 14, pp. 1459-1477.

Brinkmann, W.A.R. 1976, "Surface Temperature Trend for the Northern Hemisphere-Updated," Quaternary Research, v. 6, pp. 355-358.

Carlson, T.N. and F.E. Boland. 1978, "Analys is of Urban-Rural Canopy Using a Surface Heat Flux Temperature Mode1," Journal of Applied Meteorology, v. 17, pp. 998-1013. 
Carter, H.G. 1935, "Climate Trends in the Pacific Northwest," Monthly Weather Review, v. 63, pp. 19-23.

Cayan, D.R. and A.V. Douglas. 1984, "Urban Influences on Surface Temperatures in the Southwestern United States During Recent Decades," Journal of Climate and Applied Meteorology, v. 23, pp. 1520-1530.

Cech, I. et a1. 1976, "Relative Contribution of Land Uses to the Urban Heat Problem in the Coastal Subtropics," International Journal of Biometeorology, v. 20, pp. 9-16.

Cess, R.D. 1982, "Commentary on Modelling Climate Changes Due to Carbon Dioxide Increases," by R.E. Dickinson, In., Carbon Dioxide Review, ed. W.C. Clark, pp. 134-146, Oxford University Press.

Chandler, T.J. 1976, "Urban Climatology and Urban Planning," Geographical Journa 1, v. 142, pp. 57-59.

Changnon, S.A., Jr. 1978, "METROMEX Issue," Journal of Applied Meteorology, v. 17, pp. 565-715.

Chen, W.Y. 1985, "Seasona 1 Cl imate Summary." Monthly Weather Review, v. 114, pp. 2658-2667.

-.-.-. 1979, "What to Do about Urban-Generated Weather and C1 imate Changes," American Planning Association Journal, v. 45, pp. 36-47.

Church, P.E. 1954, "Climate of the Pacific Northwest," in The Pacific Northwest, Ed. 0.W. Freeman and H.H. Martin, New York: John WiTey and Sons. pp. 95-120.

Claggett, M. et al. 1981, "Carbon Monoxide Near an Urban Inter-Section," Atmospheric Environment, v. 15, pp. 1633-1642.

Coakley, S.M. 1979, "Climate Variability in the Pacific Northwest and its Effect on Disease of Winter Wheat," Climatic Change, v. 2, pp. $33-51$.

Colacino, M. and L. Dell 0sso. 1978, "The Local Atmospheric Circulation in the Rome Area: Surface Observations," Boundary Layer Meteorology, v. 14, pp. 133-151.

Condard, L.A. and J.C.H. van der Hage. 1971, "New Method of Air-Temperature Measurement in Urban Climatology," Atmospheric Environment, v. 5, pp. 629-635.

Eagleman, J.R. 1974, "Comparison of Urban Climatic Modifications in Three Cities," Atmospheric Environment, v. 8, pp. 1132-1142. 
Ferrar, T.A., ed. 1976, The Urban Costs of Climate Modification, New York: Wiley.

Findlay, B.F. 1976, "Meteorology as Related to Urban and Regional Planning," WMO Bullet in, v. 25, pp. 175-177.

Goodin, W.R., G.J. Mc Rae and J.H. Seinfeld. 1980, "Objective Analys is Technique for Constructing Three Dimensional Urban-Scale Wind Fields," Journal of Applied Meteorology, v. 19, pp. 98-108.

Graumlich, L.J. and L.B. Brubaker. 1986, "Reconstruction of Annual Temperature (1590-1979) for Longmire Washington, Derived from Treerings," Quaternary Research, v. 25, pp. 1520-1530.

Griffiths, J.F. 1974, "Bibliography of the Urban Modification of the Atmospheric and Hydrologic Environment," Washington: Environmental Data Service.

Gutman, D.P. and K.E. Torrance. 1975, "Response of the Urban Boundary Layer to Heat Addition and Surface Roughness," Boundary Layer Meteorology, v. 9, pp. 217-233.

Haurin, D.R. 1980, "Regional Distribution of Population, Migration, and Cl imate," Quarterly Journal of Economics, v. 95, pp. 293-308.

Henry, J.A. 1978, "Temporal and Spatial Distribution of Humidity in a Small City." Ph.D. dissertation, University Microfilm order no. 7910564.

Hsu, S-I. 1979, "Urbanization and its Effects on the Climate of Phoenix," Ph.D. dissertation, Arizona State University.

Hubley, R.C. 1956. "Glaciers of the Washington Cascade and $01 y$ mpic Mountains: Their Present Activity and its Relation to Local Climate Trends," Journal of Glaciology, v. 2, pp. 669-674.

Johnson, D.M. 1987, "Weather and Climate of Portland," in Portland Changing Landscape, Ed. L.W. Price. Occasional Paper, No. 4. Department of Geography, Portland State University. Portland, OR.

Johnson, D.M. and J.0. Dart. 1982, Variability of Precipitation in the Pacific Northwest: Spatial and Temporal Characteristics, WRRI-7T. Corvallis, 0R: Water Resources Research Institute, $182 \mathrm{pp}$.

Johnson, S. 1981, "Where Currents Merge: The Maritime Northwest," in Knowing Home, Ed. Staff of Rain, Rain Umbrella Inc. pp. 21-29.

Jones, P.A. and J.E. Jiusto. 1980, "Some Local Climate Trends in Four Cities in New York State," Journal of Applied Meteorology, v. 19, pp. 135-141. 
Jones, P.D. and P.M. Kelly. 1983, "The Spatial and Temporal Characteristics of Northern Hemisphere Surface Air Temperature Variation," Journal of Climatology, v. 3, pp. 243-252.

Jones, P.D., S.C.B. Raper, R.S. Bradley, H.F. Diaz, P.M. Kelly, and T.M.L. Wigley. 1986, "Northern Hemisphere Surface Air Temperature Variations: 1851-1984," Journal of Climate and Applied Meteorology, v. 25, pp. 161-179.

Jones, P.D., T.M.L. Wigley and P.M. Kelly. 1982. "Variations in Surface Air Temperatures: Part I. Northern Hemisphere, 1881-1980," Monthly Weather Review, v. 110, pp. 59-72.

Kalnicky R.A. 1974, "Climatic Change Since 1950," Association of American Geographers, Anna 1s, v. 64, pp. 100-113.

Kousky, V.E. 1985, "Seasonal Cl imate Summary." Monthly Weather Review, v. 113, pp. 2162-2172.

Landsberg, H.E. 1979, "Atmospheric Changes in a Growing Community (The Columbia, Maryland experience)," Urban Ecology, v. 4, pp. 53-81.

. 1979, "Man-Made Climatic Changes." Science, v. 170, No. 3964, pp. $1270-1271$.

-..-. 1981, The Urban Climate. New York: Academic Press.

Landsberg, H.E. and J.M. Mitche11. 1961, "Correspondence with Callendar," Quarterly Journal Royal Meteorological Society, v. 87, pp. $435-437$.

Landsberg, H.E. and T.N. Maise1. 1972, "Micrometeorological Observations in an Area of Urban Growth," Boundary Layer Meteorology, v. 1, pp. $61-63$.

Leahoy, D.M. 1971, "An Advective Model for Predicting Air Pollution within an Urban Heat Island with Applications to New York City," Air Pollution Control Association Journal, v. 22, pp. 548-550.

Leahoy, D.M. and J.P. Friend. 1971, "Model for Predicting the Depth of the Mixing Layer over an Urban Heat Island with Applications to New York City," Journal of Applied Meteorology, v. 10, pp. 1162-1173.

Lee, D.0. 1979, "The Influence of Atmospheric Stability and the Urban Heat Island on Urban-Rural Wind Speed Differences," Atmospheric Environment, v. 13, pp. 1175-1180.

Lee, R.L. 1973, "Theoretical Studies of Urban Heat Island Convection Effects, Ph.D. dissertation, University Microfilms order no. 73-24504. 
Lowry, W.P. 1967, "The Climate of Cities." Scientific American, v. 217, No. 2, pp. 547-553.

-.-.-. 1977, "Empirical Estimation of Urban Effects on Climate; a Problem Analys is," Journal of Applied Meteorology, v. 16, pp. 129-135.

Ludwig, F.L. 1970, "Urban Air Temperature and Their Relation to Extraurban Meteorological Measurements," Air-Condition Engineering, Publication No. SF-70-9, pp. 40-45.

McElroy, J.L. 1973, "A Numerical Study of the Nocturnal Heat Island Over a Medium-Sized Mid-Latitude City (Columbus, Ohio)," Boundary Layer Meteorology, v. 3, pp. 442-453.

Matson, M and R.V. Legeckis. 1980, "Urban Heat Is land Detected by Satellite," American Meteorological Sociaty Bulletin, v. 61, p. 212.

Matson, M. et a 1. 1978, "Satellite Dstection of Urban Heat Island," Monthly Weather Review, v. 106, pp. 1725-1734.

Mitche11, J.M., Jr. 1961, "Recent Secular Changes of Global Temperature," Annuals, New York Academy of Science, v. 95, pp. 235-250.

--.--. 1963. "Worldwide Pattern of Secular Temperature Change," In Changes of Climate; Arid Zone Research XX. Paris: UNESCO.

Moffitt, B.J. 1972, "The Effects of Urbanization on Mean Temperature at Kew Observatory," Weather, v. 27, pp. 653-656.

Morgan, D. et a1. 1977, "Microclimates within an Urban Area," Association of American Geographers, Annals, v. 67, pp. 55-65.

Myrup, L.0. 1969, "A Numerical Model of the Urban Heat Island," Journal of Applied Meteorology, v. 8, pp. 908-918.

Myrup, L.0. and D.L. Morgan. 1972, "A Numerical Model of the Urban Atmosphere," Contributions in Atmospheric Science, v. 1, no. 4, $237 p$.

Nkemdirim, L.C. 1977, "Dynamics of an Urban Temperature Field," Journal of Applied Meteorology, v. 16, pp. 818-828.

....... 1980, "Cold Air Drainage and Temperature Fields in an Urban Environment; A Case Study of Topographical Influence on Climate," Atmospheric Environment, $\vee .14, \mathrm{pp} .375-381$.

-...--. 1980, "Test of a Lapse Rate/Wind Speed Model for Estimating Heat Is land Magnitude in an Urban Airshed," Journal of Applied Meteorology, v. 19, pp. 748-756. 
NOAA (National Oceanic and Atmospheric Administration). 1985, Local Climatological Data, Annual summary, 1985: Port land, Oregon,

Oakley, S.M. 1979, "Cl imate Variability in the Pacific Northwest and its effect on Disease of Winter Wheat," Climatic Change, v. 2, pp. $33-51$.

Oke, T.R. 1973, "City Size and Heat Island," Atmospheric Environment, v. 7, pp. 769-779.

. 1974, Review of Urban C1 imatology 1968-1973. Geneva:

Secretariat of the WMO.

-...... 1976, "The Distribution between Canopy and Boundary Layer Urban Heat Islands," Atmosphere, v. 14, pp. 268-277.

-.---. 1979, Review of Urban Climatology 1973-1976. Geneva: Secretariat of the WMO.

Oke, T.R. and G.B. Maxwe11. 1975, "Urban Heat Island Dynamics in Montreal and Vancouver," Atmospheric Environment, v. 9, pp. $191-200$.

Oke, T.R. and F.G. Hannel1. 1970, "The Form of the Urban Heat Island in Hamilton, Canada," Urban Climate, WMO Technical Note No. 108, WM0-No. 254. TP. 141, Geneva, pp. 113-126.

Oujezdsky, T.W. 1973, Diurnal and Seasonal Change of the Urban Heat Is land in Austin, Texas, Springfield, Virginia: National Technical Information Service, N73-17678.

Outcalt, S.I. 1972, "A Reconnaissance Experiment in Mapping and Modeling the Effect of Land Use on Urban Thermal Regimes," Journal of Applied Meteorology, v. 11, pp. 1369-1373.

Patterson, R.D. and K.D. Hage. 1979, "Micrometeorological Study of an Urban Valley," Boundary Layer Meteorology, v. 17, pp. 175-186.

Patton, C. et al. 1976, The Atlas of Oregon, Eugene, OR. University of Oregon Press, $215 \mathrm{pp}$.

Pease, R.W. et al. 1966, "Urban Terrain Cl imatology and Remote Sensing," Association of American Geographers, Anna ls, v. 66, pp. 667-569.

Peschier, J. Jr. 1973, Wind and Temperature Profiles in an Urban Heat Is land, SpringfieTd, Virginia: National Technical Information Service, N73-17680.

Price, J.C. 1979, "Assessment of the Urban Heat Island Effect through the Use of Satellite Data," Monthly Weather Review, v. 107, pp. 1554-1557. 
Roden, G.I. 1966, "A Modern Statistical Analys is and Documentation of Historical Temperature Records in California, Oregon and Washington, 1821-1964," Journal of Applied Meteorology, v. 5, pp. 3-24.

Schreffler, J.H. 1979, "Heat Island Convergence in St. Louis during Calm Periods," Journal of Applied Meteorology, v. 18, pp. 1512-1520.

Tapper, N. J. et al. 1981, "Modeling the Winter Urban Heat Island over Christchurch, New Zealand," Journal of Applied Meteorology, v. 20, pp. 365-376.

Terjung, W.H. and P.A. O'Rourke. 1980, "Simulating the Casual Elements of the Urban Heat Islands," Boundary Layer Meteorology, v. 19, pp. 93-118.

Terjung, W.H. and S.S. Louie. 1973, "Solar Radiation and Urban Heat Island," Association of American Geographers, Annals, v. 63, pp. $181-207$.

Trewartha, G.T. 1981, The Earth's Problem Climate, 2nd Ed., Madison, WI: University of Wisconsin Press, $298 \mathrm{pp}$.

Tyson, P.D., W.J.F. Dutoit, and R.F. Fuggle. 1972, "Temperature Structure Above Cities: Review and Preliminary Findings from the Johannesberg Urban Heat Island Report," Atmospheric Environment, v. 6, pp. 533-542.

Unwin, D.J. 1976, "The Distribution between Canopy and Boundary Layer Urban Heat Islands," Atmosphere, v. 14, pp. 268-277.

-..--. 1980, "The Synoptic Climatology of Birmingham's Urban Heat Is land, 1965-1974," Weather, v. 35, pp. 43-50.

Vukovich, F.M. 1971, "Theoretical Analys is of Mean Wind Stability on Heat Island Circulation of an Urban Complex," Monthly Weather Review, v. 99, pp. 919-926.

Vukovich, F.M., J.W. Dunn and B. Crissman. 1976, "A Theoretical Study of the St. Louis Heat Island: the Wind and Temperature Distribution," Journal of Applied Meteorology, v. 15, pp. 417-440.

Vukovich, F.M. and J.W. Dunn. 1978, "A Theoretical Study of the St. Louis Heat Is land: Some Parameter Variations, "Journal of Applied Meteorology, v. 17, pp. 1585-1599.

Vukovich, F.M. and W.J. King. 1980, "Theoretical Study of the St. Lou is Heat Is land: Comparisons between Observed Data and Simulation Results on the Urban Heat Island Circulation," Journal of Applied Meteorology, v. 19, pp. 761-770. 
Vukovich, F.M. et al. 1979, "Observations and Simulations of the Diurnal Variation of the Urban Heat Is land Circulation and As sociated Varitions of the Ozone Distribution; A Case Study, " Journal of Applied Meteorology, v. 18, pp. 836-854.

Wagner, A.J. 1986, "Seasonal C1 imate Summary," Monthly Weather Review, v. 114, pp. 510-523.

Wantz, J.W., Ferris, C.M. and Larsen, N.S., 1983, "Fifteen-year Average Precipitation Patterns as Revealed by the Portland, Oregon, Mesoscale Precipitation Network," Unpublished paper, Bonneville Power Administration, Portland, OR. 13 pp.

Western SUN, 1980, Oregon Solar and Weather Information, WSUN \#11, Portland, OR. SIPp.

White, J.M., F.D. Eaton, and A.H. Auer, Jr., 1978. "The Net Radiation Budget of the St. Louis Metropolitan Area," Journal of Applied Meteorology, v. 17, pp. 593-599.

Winkler, J.A., R.H.S. Kaggs and D.G. Baker. 1981, "Effect of Temperature Adjustments on the Minneapolis-St. Paul Urban Heat Is land," Journal of Applied Meteorology, v. 20, pp. 1295-1300.

Zhou shu-zhen. 1983, "The Influence of Shanghai Urban Development on Temperature," Acta Geographica Sinica, v. 38, pp. 337-405. 


\section{APPENDIX}

MAP OF THE GENERALIZED LOCATION OF THE URBAN HEAT ISLAND IN PORTLAND, OREGON

The following diagram illustrates the generalized pattern of the urban heat island in the Portland Metropolitan Area. The heat island usually occurs in an area from Portland to Gresham in all seasons. The intensity of this heat island ranges from $4^{0}$ to $10^{\circ} \mathrm{F}$. Of the four seasons, the strongest heat island is found in winter minimum temperatures in which the spatial temperature difference is as much as $7^{0} \mathrm{~F}$. 


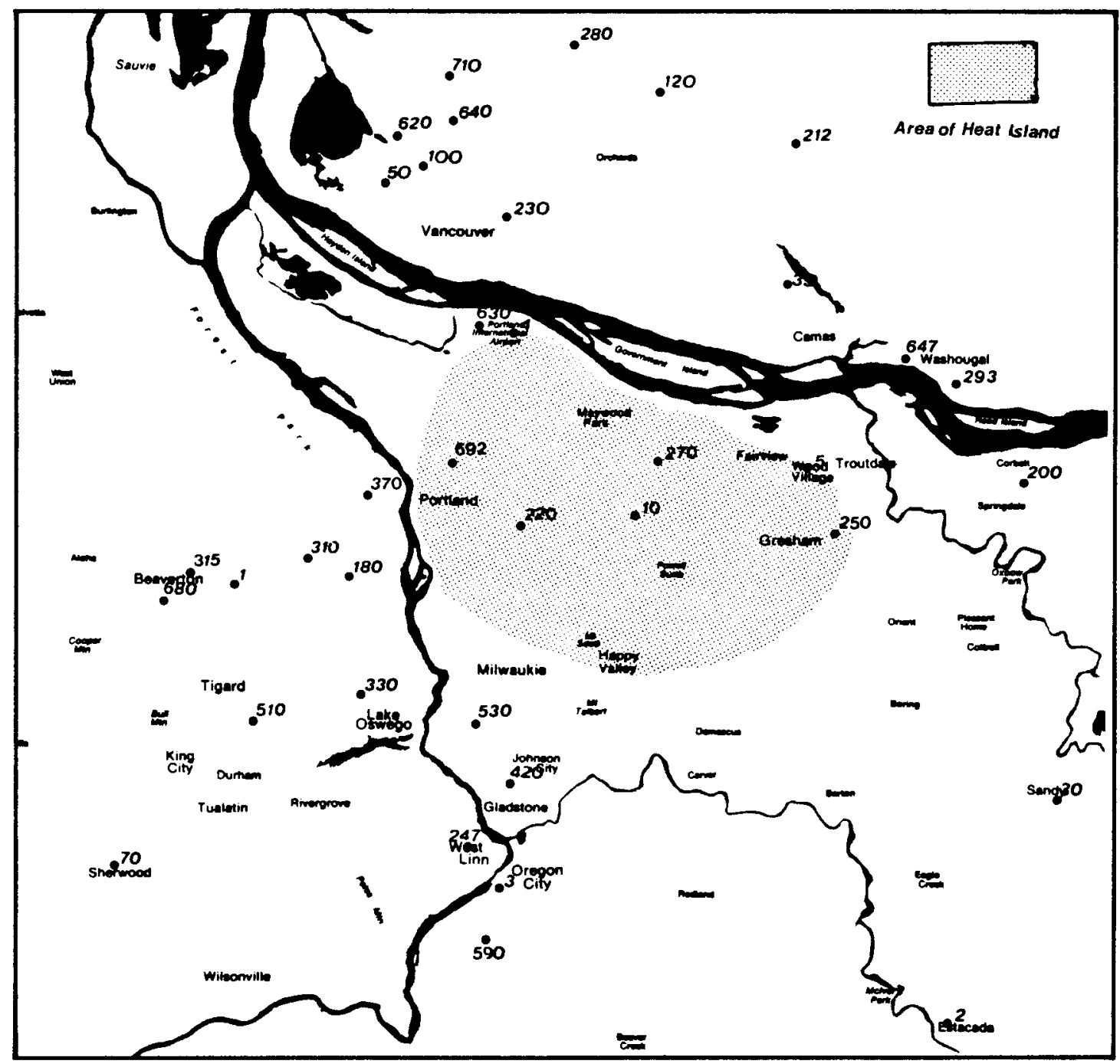

Figure 20. The generalized pattern of the urban heat island in the Portland Metropolitan area. 